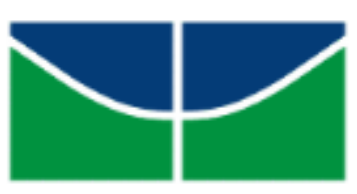

UNIVERSIDADE DE BRASÍLIA - UnB

INSTITUTO DE LETRAS - IL

DEPARTAMENTO DE LÍNGUAS ESTRANGEIRAS E TRADUÇÃO - LET PROGRAMA DE PÓS-GRADUAÇÃO EM ESTUDOS DA TRADUÇẨO - POSTRAD

\title{
O CONTO DE FADAS CONTEMPORÂNEO NA TRADUÇÃO PARA O CINEMA DE ANIMAÇÃO: THE TALE OF DESPEREAUX
}

\author{
KARINE SIMÕES DE ALENCASTRO
}

DISSERTAÇÃO DE MESTRADO EM ESTUDOS DA TRADUÇÃO

BRASÍLIA/DF

ABRIL/2016 


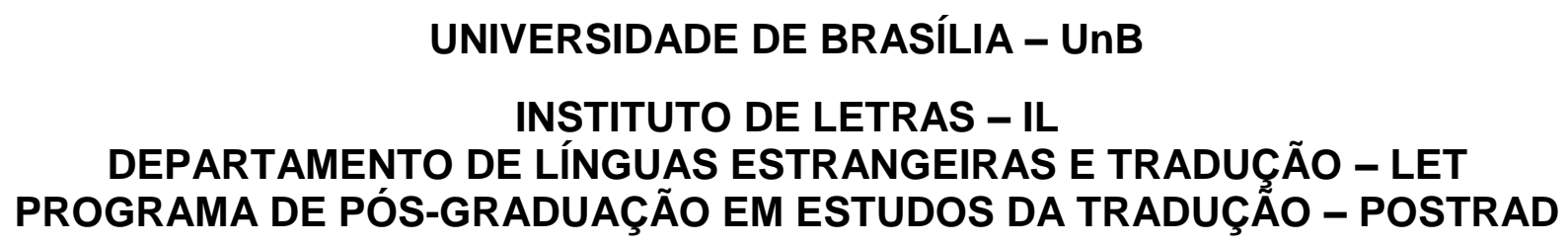

O CONTO DE FADAS CONTEMPORÂNEO NA TRADUÇÃO PARA O CINEMA DE ANIMAÇÃO: THE TALE OF DESPEREAUX

KARINE SIMÕES DE ALENCASTRO

ORIENTADOR: PROFA. DRA. SORAYA FERREIRA ALVES

DISSERTAÇÃO DE MESTRADO EM ESTUDOS DA TRADUÇÃO 


\section{REFERÊNCIA BIBLIOGRÁFICA E CATALOGAÇÃO}

\section{ALENCASTRO, Karine Simões. O Conto de Fadas Contemporâneo na Tradução para o} Cinema de Animação: The Tale Of Despereaux. Brasília: Departamento de Línguas Estrangeiras e Tradução, Universidade de Brasília, 2016,

113 f. Dissertação de mestrado.

Documento formal, autorizando reprodução desta dissertação de mestrado para empréstimo ou comercialização, exclusivamente para fins acadêmicos, foi passado pelo autor à Universidade de Brasília e acha-se arquivado na Secretaria do Programa. O autor reserva para si os outros direitos autorais, de publicação. Nenhuma parte desta dissertação de mestrado pode ser reproduzida sem a autorização por escrito do autor. Citações são estimuladas, desde que citada a fonte.

\section{FICHA CATALOGRÁFICA}

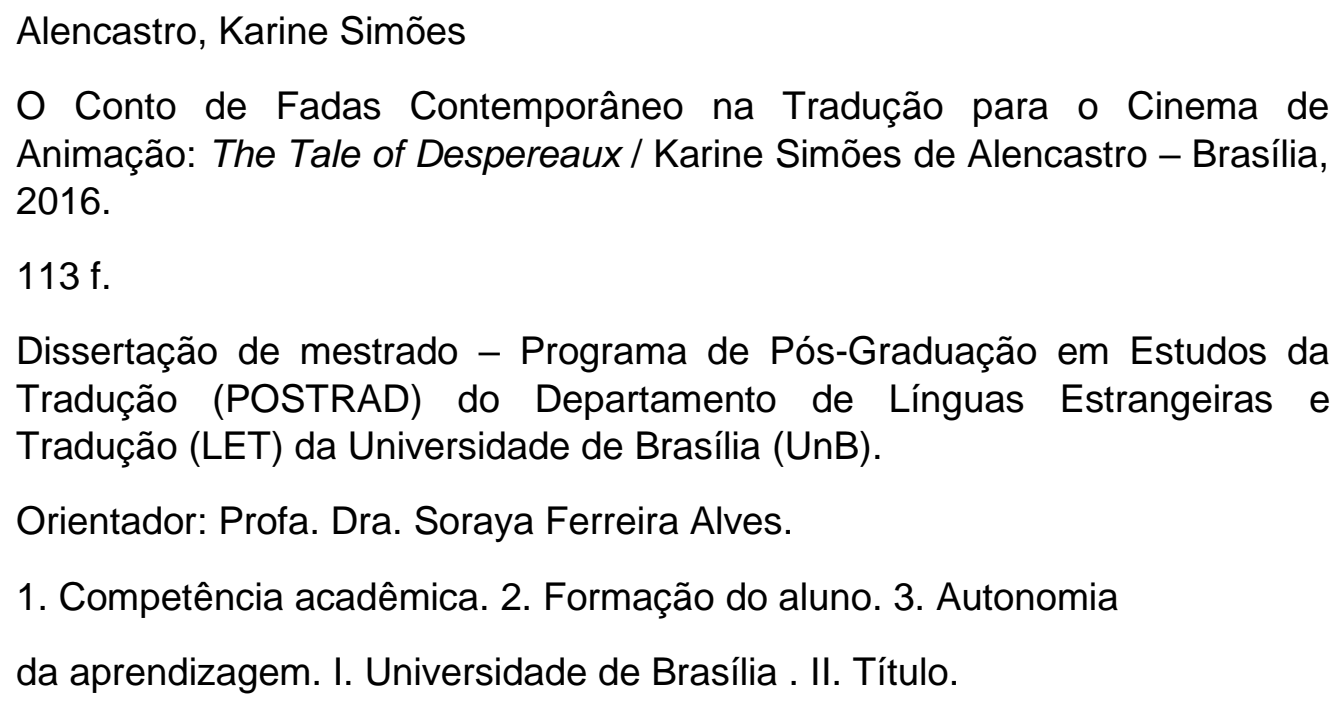

Orientador: Profa. Dra. Soraya Ferreira Alves.

1. Competência acadêmica. 2. Formação do aluno. 3. Autonomia da aprendizagem. I. Universidade de Brasília . II. Título. 


\begin{abstract}
INSTITUTO DE LETRAS - IL
DEPARTAMENTO DE LÍNGUAS ESTRANGEIRAS E TRADUCCÃO - LET

PROGRAMA DE PÓS-GRADUAÇÃO EM ESTUDOS DA TRADUÇÃ̉O - POSTRAD
\end{abstract}

O CONTO DE FADAS CONTEMPORÂNEO NA TRADUÇÃO PARA O CINEMA DE ANIMAÇÃO: THE TALE OF DESPEREAUX

KARINE SIMÕES DE ALENCASTRO

DISSERTAÇÃO DE MESTRADO SUBMETIDA AO PROGRAMA DE PÓS-GRADUAÇÃO EM ESTUDOS DA TRADUÇÃO, COMO PARTE DOS REQUISITOS NECESSÁRIOS À OBTENÇÃO DO GRAU DE MESTRE EM ESTUDOS DA TRADUÇÃO.

APROVADA POR:

PROFA. DRA. SORAYA FERREIRA ALVES - UnB

PROFA. DRA. GERMANA HENRIQUES PEREIRA - UnB

PROF. DR. CLAUDIO BRAGA - TEL/UnB

BRASÍLIA-DF, 25 de abril de 2016. 


\section{DEDICATÓRIA}

Aos verdadeiros anjos na Terra que, por enquanto, têm seu valor reconhecido somente pelos seres mais iluminados. We all share the same energy. We are all earthlings. 


\section{AGRADECIMENTOS}

Aos meus pais, pelas ideias e sugestões.

Aos meus amigos, pela paciência por minha ausência.

À professora Lúcia Targino, que, por obra do destino, me fez despertar para uma vida acadêmica.

À professora Germana Henriques Pereira de Sousa, por ter dado suporte ao meu trabalho e por ter me incentivado durante as disciplinas.

À professora Soraya Ferreira Alves, por todo apoio, compreensão, profissionalismo, orientação, estímulo e, principalmente, pela paciência.

À Melody, por lutar e adoecer comigo, aguentando firme a cada dia. 


\section{EPÍGRAFE}

Meditação traz sabedoria; a falta de meditação deixa a ignorância. Saiba bem o que lhe conduz para frente e o que lhe prende atrás, e escolha o caminho que o guie à sabedoria.

Siddharta Gautama 


\section{RESUMO}

O livro premiado The Tale of Despereaux: being the story of a mouse, a princess, some soup, and a spool of thread (2003), de Kate DiCamillo, chegou às escolas europeias e americanas após ser considerado o melhor livro do ano para crianças pela Publishers Weekly e receber o Newbery Medal em 2004. Em 2008, sua obra ganhou uma animação, com repercussão internacional, com as vozes de diversas celebridades hollywoodianas como Dustin Hoffman, Sigourney Weaver, Emma Watson e Matthew Broderick. O sucesso do livro como instrumento pedagógico suscitou a iniciativa de uma análise de sua adaptação cinematográfica. Tendo-se em mente as limitações do sistema audiovisual bem como os cuidados com os tipos e o grau de exposição, orientados pela classificação indicativa, tem-se por objetivo fazer um estudo comparativo entre obra literária e fílmica a fim de se verificar como se constrói o ponto de vista dos personagens diante das adversidades e como se dá o efeito moral em cada sistema semiótico à luz de teorias relacionadas à recepção, à interculturalidade, à literatura humanizadora e aos Estudos da Tradução. Para isso, são utilizadas as concepções de Bruno Bettelheim (1980), Canton (1994), Monaci (1990), Khéde (1990), Coelho (2000) sobre contos de fadas e Riche (1999), Azevedo (2008) e Silva, Diogo e Azevedo (2008) sobre o conto de fadas contemporâneo. O estudo sobre adaptação como processo sociocultural de Foucault (1993), Cechin (2014), Larrosa (1996), Silva (2007) serve como base para análise da adaptação pautada no conceito de Léfévere (2007) sobre a relação entre reescritura e patronagem, e a definição de Baker (2005) sobre adaptação local x global, a depender do contexto sociocultural. Estas perspectivas estão paralelas à pesquisa de Xavier (2003), Eisenstein (1969), Diniz (1999) e Metz (1972) sobre, especificamente, adaptação cinematográfica. Partindo-se desta concepção, é investigado o ponto de vista em ambas as versões com o objetivo de se investigar as estratégias de tradução na construção dos personagens Miggery Sow, Despereaux e Chiaroscuro, fazendo-se considerações sobre as restrições inerentes ao sistema semiótico no qual a animação se encontra. É examinado o grau de similaridade e disparidade entre filme e livro, visando acréscimos e omissões, assim como por meio dos estudos de Marcel Martin (2003), Bazin (1991), e Friedman (2002), sobre linguagem cinematográfica, adaptação fílmica e pontos de vista, verifica-se as estratégias de adaptação a partir dos planos cinematográficos. Como resultado, observam-se os contrastes da adaptação advindos da mudança de sistema semiótico, das convenções sociais relacionadas à cultura ocidental do século XXI e às restrições da indústria do cinema.

Palavras-chave: Tradução Intersemiótica; Reescritura; Cinema de Animação; Literatura Infantojuvenil. 


\begin{abstract}
The award-winning book The Tale of Despereaux: being the story of a mouse, a princess, some soup, and a spool of thread (2003), written by Kate DiCamillo, reached the European and American schools after being considered the best children's book of the year by Publishers Weekly and receiving the Newbery Medal in 2004. In 2008, the book won a version as an animated movie, with international repercussions, being voiced by several Hollywood celebrities like Dustin Hoffman, Sigourney Weaver, Emma Watson and Matthew Broderick. The success of the book as an educational tool has raised the initiative of an analysis of its film adaptation. Bearing in mind the limitations of the audiovisual system and the care of the types and degree of exposure, guided by the age rating, it aims to make a comparative study of literary and filmic narrative in order to verify how to build the point of view of the characters in the face of adversities and how is the moral effect on each semiotic system relating the analysis to theories of reception, interculturalism, humanizing literature and Translation Studies. To make this study possible, the concepts on fairy tales made by Bruno Bettelheim (1980), Canton (1994), Monaci (1990), Khéde (1990), Rabbit (2000) and the studies on the contemporary fairytale made by Riche (1999), Azevedo (2008) and Silva, Diogo and Azevedo (2008) are used as corpus. The study of adaptation and sociocultural process of Foucault (1993), Cechin (2014), Larrosa (1996), Silva (2007) serves as foundation for the analysis of adaptation guided by the concept of Lefevere (2007) on the relationship between rewriting and patronage, and the definition of Baker (2005) on the local x global adaptation, depending on the sociocultural context. These prospects are parallel to the research made by Xavier (2003), Eisenstein (1969), Diniz (1999) and Metz (1972) on specifically film adaptation. The point of view is investigated in both systems based on these concepts in order to verify the translation strategies in the construction of the characters Miggery Sow Despereaux and Chiaroscuro. Considerations are made about the restrictions inherent to the semiotic system in which the animation is. The degree of similarity and disparity between film and book is examined, focusing on additions and omissions, as well as through studies made by Marcel Martin (2003), Bazin (1991) and Friedman (2002) about film language, film adaptation and points of view, adaptation strategies are checked from film plans. As a result, the contrast is observed coming from adaptation of change of semiotic system, social conventions related to Western culture of the XXI century and the restrictions of the film industry.
\end{abstract}

Keywords: Intersemiotic Translation; Rewriting; Animated movie; Children's Literature. 


\section{LISTA DE ILUSTRAÇÕES}

Página

Figura 1 - Características diferenciadas de Despereaux ao nascer............................. 60

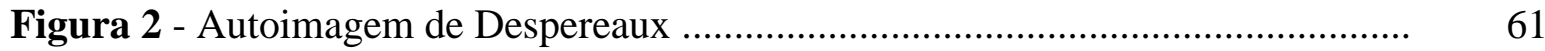

Figura 3 - Reação dos colegas de Despereaux na escola........................................... $\quad 62$

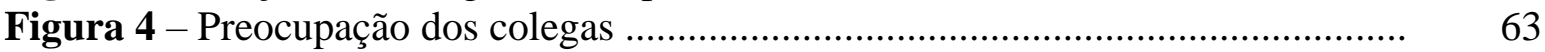

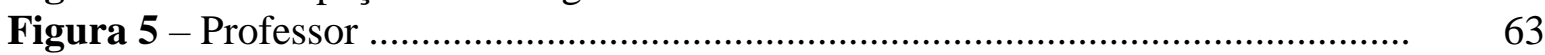

Figura 6 - Covardia de Lester ......................................................................... 64

Figura 7 - Sentimentos de Lester e Antoinette ...................................................... 65

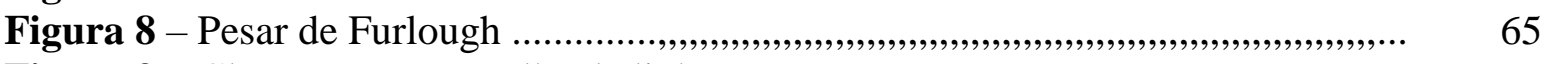

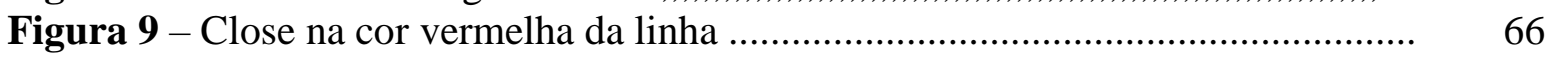

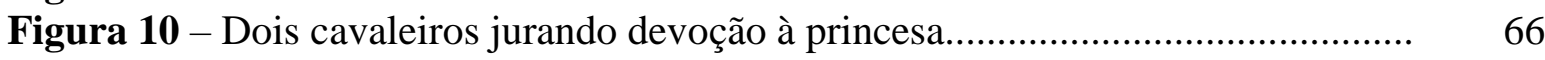

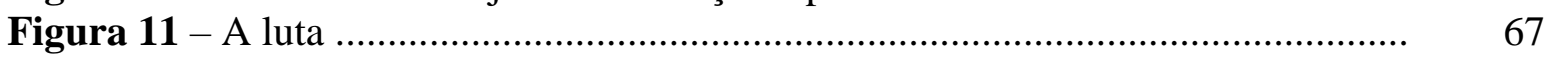

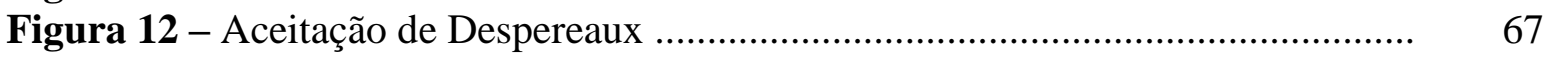

Figura 13 - Pai de Miggery entregando-a, ainda bebê, para uma mulher ................... 71

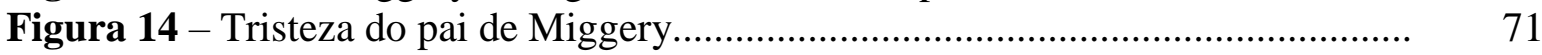

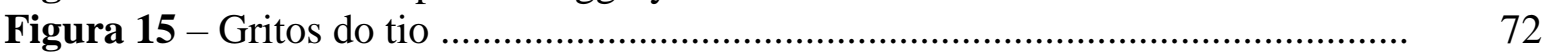

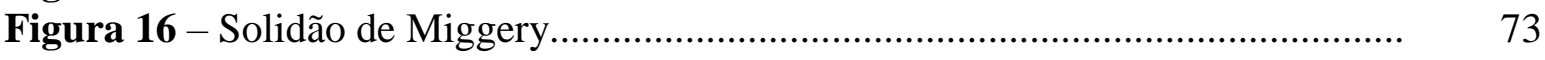

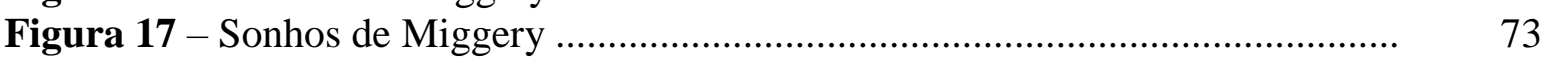

Figura 18 - Tristeza de Miggery .................................................................... 74

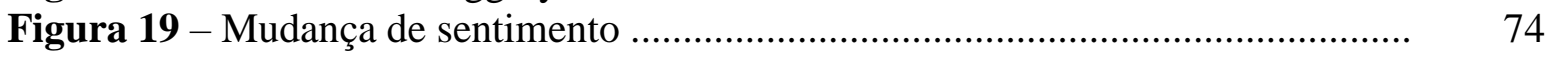

Figura 20 - Marca de nascença no pescoço de Miggery ........................................ 75

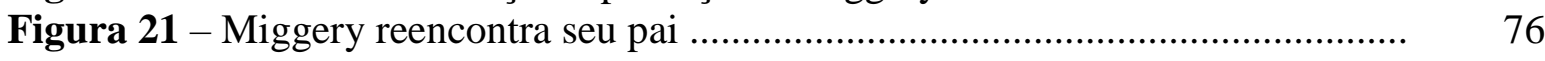

Figura 22 - Coroa real ...........................................................................

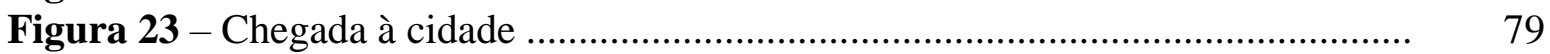

Figura 24 - Susto da Rainha e da Princesa ........................................................... 79

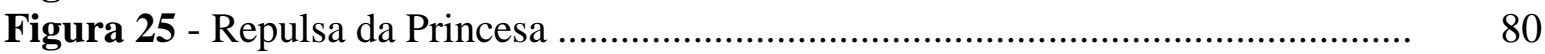

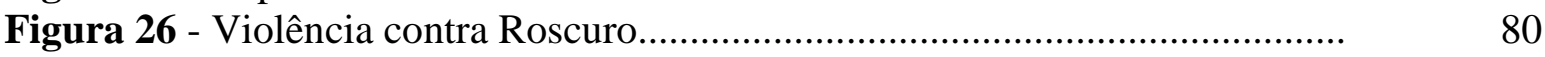

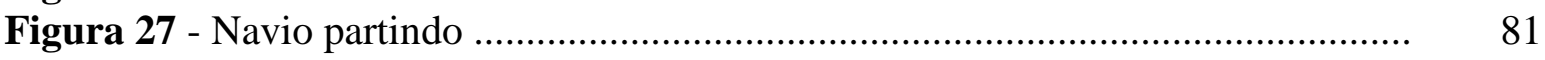

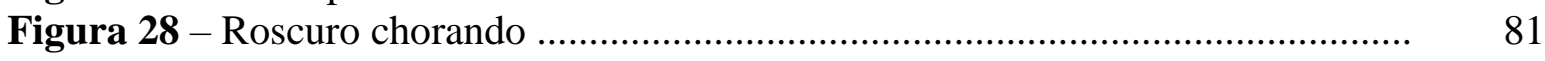

Figura 29 - Dificuldade em integrar-se ........................................................ 82

Figura 30 - Expressões de Roscuro ............................................................. 82

Figura 31 - Tristeza de Roscuro transformando-se em ódio ..................................... 83

Figura 32 - Roscuro pede perdão à Princesa Pea ................................................ 84

Figura 33 - Roscuro consegue liberdade e retorna ao navio .................................. 84

Figura 34 - Solidão da Princesa Pea após a morte de sua mãe ................................. $\quad 86$

Figura 35 - Solidão do Rei após a morte da Rainha ................................................... 87

Figura 36 - A majestade de Pea ......................................................................... 88

Figura 37 - Princesa Pea se reaproxima do pai .................................................. 88 


\section{LISTA DE TABELAS}

\section{Página}

Tabela 1 - Personagem Despereaux: livro e animação..........................................

Tabela 2 - Construção do personagem Miggery no livro e na animação..................

Tabela 3 - Personagem Roscuro: livro e animação................................................. 


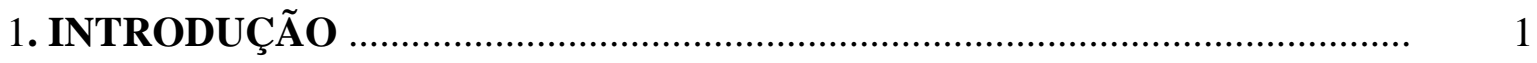

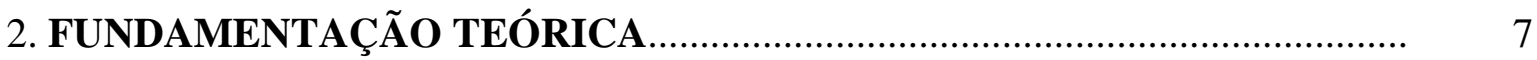

2.1. Tradução audiovisual nos Estudos da Tradução................................................... 7

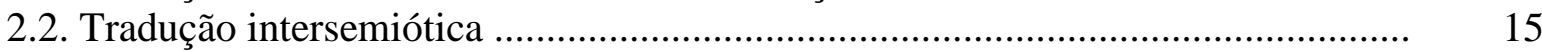

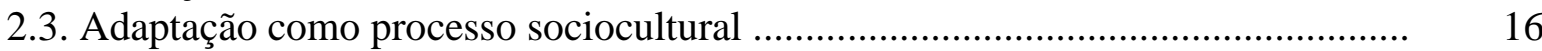

3. LITERATURA INFANTOJUVENIL ................................................... 21

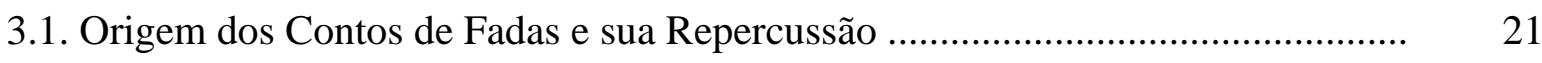

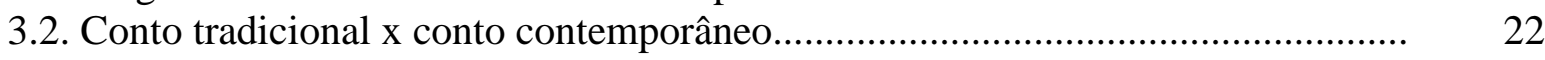

3.3. Literatura humanizadora .................................................................................... 29

3.4. A obra literária: The Tale of Despereaux: being the story of a mouse, a princess, some soup, and a spool of thread .......................................................................... 31

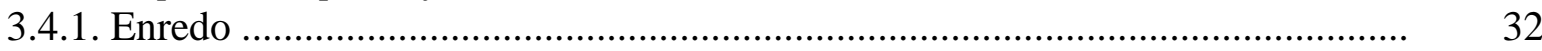

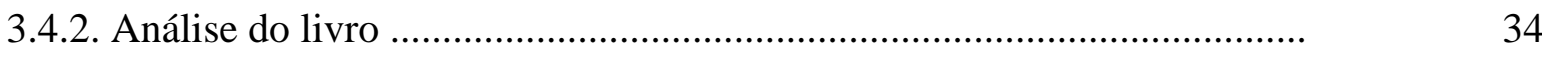

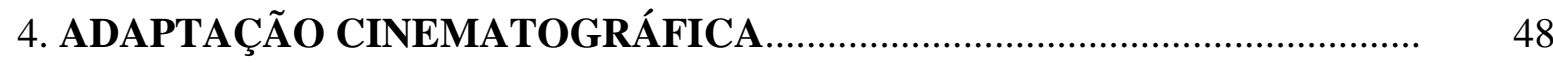

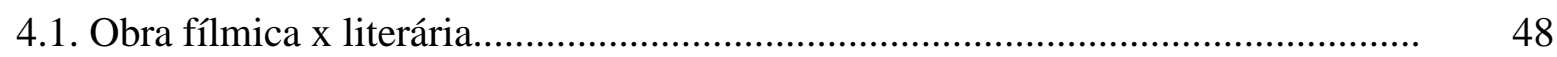

4.2. Técnicas cinematográficas na construção da narrativa e dos pontos de vista........ 50

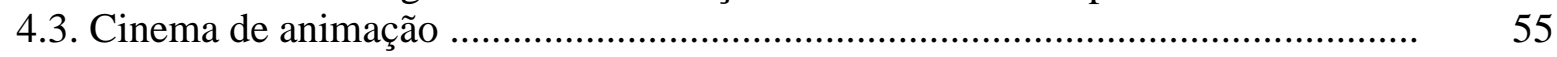

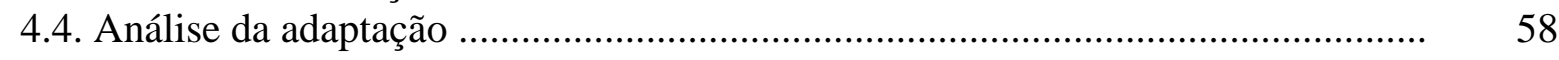

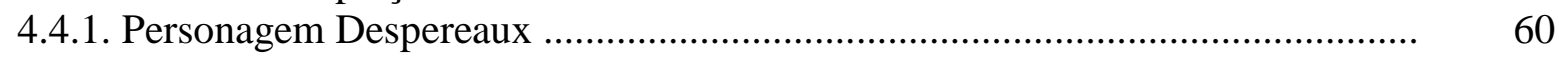

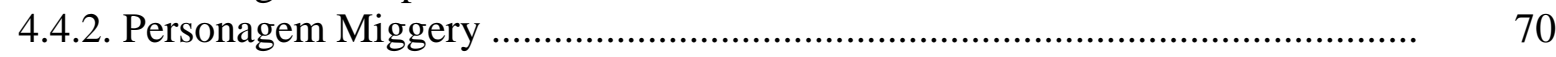

4.4.3. Personagem Roscuro..........................................................................................

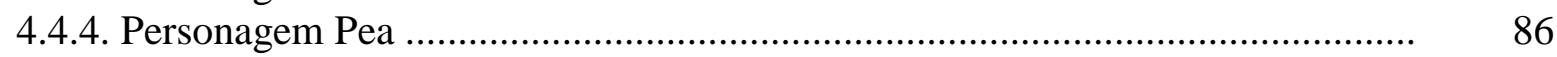

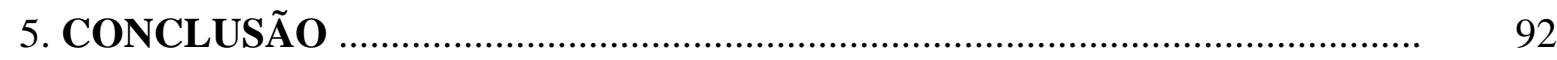

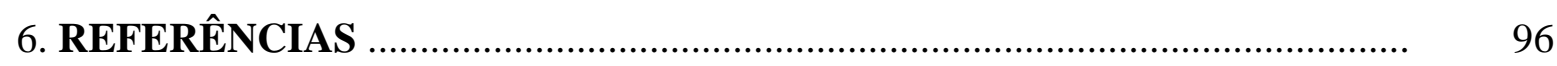




\section{INTRODUÇÃO}

A prática de contação de histórias, mais precisamente, dos contos de fadas, foi, originalmente, concebida durante reuniões sociais entre camponeses e outros trabalhadores como forma de entretenimento e exteriorização de conflitos existenciais. Famílias inteiras sentavam-se e ouviam narrativas que faziam parte do imaginário do povo, fazendo menção a, inclusive, práticas sexuais e de extrema violência.

Por muito tempo, jovens e adultos tiveram contato com a barbárie retratada nos contos de fadas e, somente a partir do final século XVII, quando se percebeu o potencial da criança para assimilar os valores da burguesia, foram feitos questionamentos sobre o que seria adequado para seu desenvolvimento como indivíduo. Por conseguinte, essas narrativas passaram a ser adaptadas para o público infantil e, aquelas que expunham simulações de agressão foram, pouco a pouco, sendo suprimidas por seus contadores.

Com o passar dos anos, a tradicionalidade dos contos de fadas foi dando lugar a uma escrita mais contemporânea ao se criar enredos cada vez mais politicamente corretos, ou seja, introduzindo críticas a papeis sociais preestabelecidos e a atitudes que prejudiquem moralmente um dos personagens.

Sabendo-se dessa transição, o livro infantojuvenil The Tale of Despereaux: Being the Story of a Mouse, a Princess, Some Soup, and a Spool of Thread (2003), da autora britânica Kate DiCamillo, revela-se como uma combinação entre os contos de fadas tradicionais e contemporâneos estruturada em forma de romance. Com acontecimentos similares aos dos contos de fadas de antigamente, como violência, abandono, redenção, perdão e esperança, a narrativa expõe de forma trágica o desenrolar da vida de três protagonistas, um camundongo, uma ratazana e uma menina, em espaço e tempos distintos e aprofunda, por meio do apelo a uma reflexão filosófico-cultural por parte do narrador, um estudo psicológico desses personagens, ao sofrerem grandes desilusões.

A obra literária é dividida em 4 seções, denominadas "livros". A primeira seção conta a história de Despereaux, desde seu nascimento até o momento presente. Ele é um camundongo nascido no castelo que, por nascer com algumas particularidades, é tratado de 
forma diferente por seus parentes e colegas. Eterno sonhador, vê beleza em tudo ao seu redor e, ignorando sua condição, decide ser como o cavaleiro das histórias que lê.

A segunda seção conta a história de Miggery Sow, uma menina órfã de mãe que foi trocada por um maço de cigarro, um pano vermelho e uma galinha por seu pai. Ela realiza trabalho escravo na casa onde mora e, tempos depois, é levada para o castelo para ter uma oportunidade de trabalho. Sonhando em ser uma princesa, é convencida por Chiaroscuro de sequestrar a Princesa Pea para tomar seu lugar.

A terceira seção apresenta Chiaroscuro, uma ratazana apaixonada pela luz que, ao ir ao castelo durante um festival, sente o cheiro da sopa real, prato elaborado todos os anos para alimentar o povo da cidade. Ele sobe em um lustre para sentir melhor seu aroma e cai diretamente no prato da rainha que, ao vê-lo, sofre um ataque cardíaco. O olhar de repúdio da Princesa Pea, em virtude da morte da mãe, desencadeia nele diferentes sentimentos que o levam a querer vingança, pela maneira como foi tratado.

Por fim, a última seção expõe os três protagonistas juntos, enfrentando seus conflitos internos, ao exemplo de Despereaux tentando salvar a princesa do sequestro e provando seu valor, Roscuro pedindo perdão a ela por seus atos e saindo em busca de um novo lar, Miggery reconciliando-se com o pai e sendo tratada por ele como a princesa que gostaria de ser e o reino voltando a ter alegria e esperança.

Separadamente, cada uma dessas seções relata a história de vida dos protagonistas, identificando-se todos os acontecimentos que os levaram a agir de tal forma no presente. A narrativa é tecida a partir dos pontos de vista dos três personagens somados ao do narrador, sempre apontando posturas indevidas e suas consequências. Essa construção do ponto de vista é essencial para o desenrolar da trama, pois incentiva o leitor ao pensamento crítico, ao ser convidado pelo narrador a interagir com a obra.

A narrativa expõe as consequências de imposições hierárquicas de convenções sociais sobre os três personagens, tidos como injustiçados pelas sociedades nas quais vivem. A esperança é um elemento comum entre eles e a história mostra a perspectiva de cada um com relação à perseverança, aceitação e redenção. Estas situações, de modo geral, demonstram, 
nas três sociedades, a dos camundongos, a das ratazanas e a dos humanos, a intolerância com os protagonistas por não seguirem ou não se adequarem às regras.

Com o uso do vocativo, o narrador onisciente repreende certos comportamentos dentro dessas sociedades, enfatizando lições de cunho moral, trazendo o leitor à história por meio de situações hipotéticas e questionamentos sobre o que este faria em tal contexto. Destarte, ele norteia a criança por meio da explanação dos sentimentos e do porquê de certas atitudes dos personagens em circunstâncias complexas. Desta forma, os valores a serem passados são previamente delimitados pelo narrador, que faz o leitor questionar-se sobre o que é certo e errado durante a narrativa.

A literatura como humanizadora torna-se indispensável ao desenvolvimento intelectual da criança, ao passo que estimula a imaginação e a capacidade de reflexão diante de adversidades nas tramas. Ao promover o contato com diversas formas de experiências humanas, esse tipo de leitura pode, segundo Morin (2005, p.17-180), modificar o ensino e, como consequência, o conhecimento humano. De acordo com ele, "É, pois, na literatura que o ensino sobre a condição humana pode adquirir forma vívida e ativa para esclarecer a cada um sobre sua própria vida" (MORIN, 2005, p. 49).

Tendo vários elementos na história que servem de efeito moral e um narrador mais incisivo, que se utiliza de uma abordagem socioeducativa, o livro ganhou novas edições, adaptadas para várias faixas etárias, com perguntas sobre interpretação de texto e questionamentos ético-morais para serem utilizadas em escolas na Europa e nos Estados Unidos, e esteve 90 semanas no topo do New York Times, sendo considerado o melhor livro do ano para crianças pela Publishers Weekly e recebendo o Newbery Medal em 2004.

Sendo o segundo maior sucesso da autora, também premiado como livro discente - o primeiro foi Because of Winn-Dixie (2000) no Teachers' Top 100 Books for Children -, The Tale of Despereaux: being the Story of a Mouse, a Princess, Some Soup, and a Spool of Thread (2003) foi traduzido para mais de 13 países, incluindo Vietnam, Japão e China. No Brasil, foi traduzido, em 2005, pela editora Martins Fontes, mantendo-se as mesmas ilustrações, ao contrário de outras edições. Posteriormente, teve sua obra adaptada para a animação anglo-americana, em 2008, com o título de The Tale of Despereaux, dirigida por 
Sam Fell e Robert Stevenhagen, com as vozes de algumas celebridades hollywoodianas como Sigourney Weaver, Dustin Hoffman, Emma Watson e Matthew Broderick.

O livro como obra contemporânea com traços dos contos de fadas surgidos no século XVII proporciona ao leitor em desenvolvimento a possibilidade de maior absorção dos ensinamentos propostos. Isso porque a exposição de eventos violentos ao pequeno leitor, segundo Bettelheim (1980), ocorre de maneira subjetiva, direcionando-o para a resolução de seus conflitos internos.

O mistério nas tramas permite à criança lidar com passagens violentas reorganizandoas de acordo com sua compreensão de mundo. Seu prazer na história é impulsionado pelo sentimento de medo, sensação que nos protege da morte, e a curiosidade de senti-lo supera essa função de defesa e possibilita coragem e expansão das pulsões da vida. Essas narrativas fantasiosas, às vezes, encarnam desejos que nutrimos ou temores que padecemos, sempre sendo selecionadas pelo leitor de acordo com sua identificação, não necessariamente de modo direto (CORSO, 2006, p.17-20).

No meio audiovisual, essa exposição é velada devido à mudança de sistema semiótico ao qual a história será vinculada. Embora filmes, de modo geral, cada vez mais, deem legitimidade à inserção de sexo e violência, isso não desconsidera a discussão sobre limites, motivos e circunstâncias que se faz conforme o contexto social em que o debate se dá (XAVIER, 2003, p.74-75). Em uma animação, há, especialmente, fatores ligados à adequação específica conforme a faixa etária, que, no caso desta animação, situa-se na classificação indicativa livre.

Outra questão é que a especificidade de cada tipo de linguagem traz diferentes perspectivas ao público e é necessário avaliar até onde vai a liberdade do tradutor com relação a acréscimos e omissões no filme, principalmente porque "a mídia só trabalha com o reconhecível, o padronizável e, sobretudo com o que se vende mais e com mais velocidade...” (SANTAELLA, 2004 p.81).

Com as narrativas literária e audiovisual mantendo fortemente a presença de um narrador, questiona-se de que forma se dá essa atuação e quais foram as consequências dessa passagem. Posto isso, este trabalho tem como objetivo realizar um estudo comparativo entre o 
livro e animação a fim de se verificar como se constroem os pontos de vista na adaptação de uma obra contemporânea calcada no conto de fadas tradicional. Tal reflexão provoca os seguintes questionamentos:

1- As estratégias utilizadas na adaptação alteram o efeito moral?

2- Há interferência de pontos de vista? Quais suas implicações?

3- Como se dá a atualização do tradicional para o contemporâneo?

4- Qual é o papel do narrador em cada sistema semiótico?

Para se responder a essas perguntas, será realizada uma pesquisa descritiva, qualitativa e bibliográfica sobre as implicações da tradução intersemiótica de uma obra literária infantil para uma animação que tem de se adequar às restrições de um sistema midiático padronizado. A partir dos valores pré-estabelecidos no livro, serão analisados os temas recorrentes dos contos de fadas tradicionais de modo a se verificar como se empregam essas temáticas em uma obra contemporânea. Para isso, serão utilizadas as concepções de Bruno Bettelheim (1980), Canton (1994), Monaci (1990), Khéde (1990), Coelho (2000) sobre contos de fadas e Riche (1999), Azevedo (2008) e Silva, Diogo e Azevedo (2008) sobre o conto contemporâneo. O estudo sobre adaptação como processo sociocultural de Foucault (1993), Cechin (2014), Larrosa (1996), Silva (2007) servirá como base para análise da adaptação pautada no conceito de Léfévere (2007) sobre a relação entre reescritura e patronagem e a definição de Baker (2005) sobre adaptação local x global, a depender do contexto sociocultural. Estas perspectivas estarão paralelas à pesquisa de Xavier (2003), Eisenstein (1969), Diniz (1999) e Metz (1972) sobre, especificamente, adaptação cinematográfica. Partindo-se desta concepção, será investigado o ponto de vista em ambas as versões com o objetivo de se verificar as estratégias de tradução na construção dos personagens Miggery Sow, Despereaux e Chiaroscuro, fazendo-se considerações sobre as restrições inerentes ao sistema semiótico no qual a animação se encontra. Será examinado o grau de similaridade e disparidade entre filme e livro, visando acréscimos e omissões, bem como por meio dos estudos de Marcel Martin (2003), Bazin (1991), e Friedman (2002), sobre linguagem cinematográfica, adaptação fílmica e pontos de vista, verificar-se-á as estratégias de adaptação a partir dos planos cinematográficos. 
$\mathrm{Na}$ primeira parte deste trabalho, será feito um apanhado geral sobre a tradução audiovisual e a tradução intersemiótica nos Estudos da Tradução para que se possa situá-las paralelamente a estudos intersemióticos e culturais. Nesse sentido, será explicado como se dá uma adaptação voltada para o público infantil com traços de uma literatura gerada décadas atrás. Tendo-se essa noção, a segunda parte abarcará as diferenças entre o conto de fadas tradicional e o contemporâneo como responsáveis pela formação da criança, mostrando-se diferentes olhares conforme a contextualização temporal, expondo-se uma análise do livro baseada em tais divergências. A última parte terá por base a discussão cinema versus literatura e a construção do ponto de vista nos diferentes sistemas semióticos, analisando-se os planos cinematográficos em comparação à análise do livro para que se verifiquem as implicações dentro da temática da discussão sociocultural proposta pela narrativa. 


\section{FUNDAMENTAÇÃO TEÓRICA}

\subsection{Tradução audiovisual e os Estudos da Tradução}

Quando o assunto em pauta envolve tradução, estabelecem-se questões polêmicas em torno do que é certo ou errado. A principal adversidade encontrada em seu processo é a busca pela equivalência, assunto tão debatido entre teóricos, que tem por objetivo avaliar sua forma e condição. Trazendo essas ideias para o contexto da recepção, a tradução é defendida por diferentes ângulos.

Para Schleiermacher (2001, p.43), o tradutor pode escolher dois caminhos: "ou deixa o autor em paz e leva o leitor até ele, ou deixa o leitor em paz e leva o autor até ele". No primeiro caso, privilegiam-se as características do texto original ao passo que no segundo, faz-se com que seu texto pareça fluente na língua de chegada. Ele defende que, ao trazer o público para o autor, a possibilidade de êxito será maior pelo fato de se realçar a beleza do original.

Por esse caminho, o leitor da tradução percebe, por meio do estranhamento, que está lendo uma tradução, pois há uma pressão etnodesviante sobre a cultura receptora para a introdução de elementos linguísticos e culturais do estrangeiro. Lawrence Venuti (1998) chama esse processo de estrangeirização. Nesse sentido, parte-se da noção de que a tradução também pode promover o enriquecimento da língua de chegada.

A domesticação, por sua vez, quando pensada em um contexto tradutório de uma cultura dominante sobre uma cultura dominada, pode impor estereótipos e valores de modo a estigmatizar etnias e nacionalidades específicas devido a comportamentos patrióticos, racistas e etnocêntricos (VENUTI, 1986, p.130).

Essa concepção aproxima o autor do leitor da tradução por meio de um texto fluido, que mascara o texto estrangeiro em detrimento dos valores da cultura receptora. Nessa perspectiva, Venuti (2002, p.166) acredita que o ideal seria um distanciamento de normas 
domésticas para que o público-leitor pudesse ser mais aberto com relação às diferenças linguísticas e culturais, retirando os elementos estilísticos que alienem a obra e a levem ao fracasso (VENUTI, 2002, p.166).

Venuti (1986, citado por MARTINS, 2010, p.68) opta por traduzir obras que sejam marginalizadas dentro de suas próprias culturas que possam vir a ser úteis no processo de redução da dominação cultural e dialetal do inglês americano. Ele deixa claro que seu posicionamento decorre da ascensão política e econômica dos Estados Unidos, que reduziu as línguas estrangeiras a minorias (MARTINS, 2010, p.68).

Pode-se dizer cada teoria insere o tradutor em determinado paradigma. Enquanto uns acreditam na adaptação da obra aos moldes da língua receptora, outros a veem como instrumento de inovação. Vale lembrar que esses textos estão sendo inseridos em contextos socioculturais diferentes da língua de partida, o que necessariamente acarretará mudanças.

Mesmo lidando com culturas muito diferentes, alguns tradutores tentaram se ater somente ao texto. Os teóricos da França, no século XVII, utilizaram a expressão "belas infiéis", partindo do pressuposto de que para se produzir uma boa tradução seria necessário fazer modificações e acréscimos de modo a embelezar o texto-alvo.

Pelo ponto de vista da linguística, John Catford (1965) tentou analisar as traduções a partir de semelhanças e diferenças entre línguas. Ele tentou estabelecer, de modo prescritivo, probabilidades de equivalência pela utilização da linguística como base para uma sistematização de normas tradutórias. Eugene Nida (1969), em contrapartida, propôs utilizá-la como instrumento de análise para a solução de adversidades relacionadas a essa transição.

Pensando-se somente pelo lado textual, tais concepções, de certa forma, tornam-se inviáveis, tendo em vista a variedade de aspectos que influenciam a tarefa tradutória. Quando falamos no processo de tradução, é preciso considerar as relações vigentes as quais fazem/farão parte deste para que suas significações e ressignificações se adequem conforme exigir a situação.

Walter Benjamin (1979, p.38) acredita que a tradução transfere o sentido original de um texto para outro definitivo, que poderá ser renovado em diversos contextos, tendo de 
renunciar à finalidade de apenas comunicar. Ao ter o original somente como apoio, a tradução isenta o tradutor do sistema daquilo que é comunicado, embora sua linguagem possa se desprender do significado para que a tradução seja um complemento à língua-fonte, e não uma reprodução.

Com o tempo, os Estudos da Tradução permitiram novas maneiras de se entender o diálogo que ocorre entre o texto e os aspectos sociais do sistema da cultura-alvo. A junção de teorias literárias, comunicativas e semióticas contribuíram para a utilização de abordagens que fizeram os Estudos da Tradução saírem da relação palavra e texto, para aterem-se, também, à cultura e à história, levando o foco para o texto-meta e o público-alvo da tradução.

Essa mudança de cenário, somada a alguns estudos sobre recepção, criaram uma atmosfera capaz de se pensar na literatura como um sistema, teoria retomada inicialmente pelos formalistas russos e posteriormente, na década de 1970, pelo teórico israelense da Escola de Tel Aviv, Itamar Even-Zohar, ligado aos estudos descritivos da tradução (MARTINS, 2010, p.2).

Para Even-Zohar (1979), as estratégias e decisões tradutórias serão determinadas à luz das normas e convenções sociais da cultura de chegada. $\mathrm{O}$ texto passa a ser incorporado ao meio literário ao qual ele fará parte. Desta forma, ao agregar fatores históricos e culturais ao processo tradutório, contribui-se para a perspectiva que ultrapassa a percepção inicialmente concebida ao ato tradutório de transferência de palavra para palavra. Nesse sentido, ele criou a Teoria dos Polissistemas, que ressalta a heterogeneidade e a multiplicidade das relações na cultura, abordando fenômenos semióticos como um polissistema composto por elementos que se interceptam e se sobrepõem funcionando ainda como estrutura com membros interdependentes (EVEN-ZOHAR, 1979, p.290).

Andre Lefevère dá continuidade a algumas dessas concepções, mas detém-se em parte delas. Fundamentando-se na Teoria dos Polissistemas, o teórico, ao priorizar o polo receptor, prevê a impossibilidade de recuperação de elementos, tendo-se por base que o contexto de recepção é diferente de sua produção. Com isso, ele analisa os fatores que influenciaram traduções em diferentes épocas. 
Dessa forma, a literatura vista como um dos sistemas que interagem com a cultura é então conduzida por condições internas - tradutores, críticos - e externas (poder político, social e econômico na cultura de chegada). Ele afirma que "do ponto de vista do sistema receptor, toda tradução implica certo grau de manipulação do texto-fonte, com um determinado objetivo" (HERMANS, 1985, p. 9).

Lefevère e Susan Bassnett (1990, apud MARTINS, 2010, p.4) associam tradução a uma manipulação quando afirmam que a tradução é uma reescrita de um texto original e que, como toda reescrita, independentemente da intenção com que foi produzida, reflete uma ideologia e uma poética, manipulando assim a literatura para funcionar na sociedade de certa maneira.

Sejam baseadas em mercado ou em fatos históricos, as traduções, segundo André Lefèvere (2007), devem se moldar a partir da cultura de chegada, levando-se em conta a pragmática e a contextualização, afetando diretamente as estratégias e as decisões a serem tomadas, em um processo dialético de apropriação e inovação pela tradução. Para o teórico, a tradução é uma reescritura que tem por objetivo a inovação literária ou cultural, e o processo para sua aceitação ou canonização depende do pano de fundo da ideologia do momento somado às relações de poder.

Embora este trabalho não tenha como objetivo entrar a fundo nos estudos descritivistas, é importante mostrar o caminho percorrido por André Lefèvere na edificação de sua teoria sobre reescritura. Seus estudos seguem a linha da substituição dos aspectos formais pelos fatores extratextuais que colocam o leitor como intermédio na produção de sentido do texto. Com isso, concebe-se uma atividade orientada pela recepção, divulgação e avaliação dos diferentes contextos socioculturais (VIEIRA, 1996, p.138).

Ele salienta o papel dos agentes de continuidade na formação de cânones literários, explicitando as relações de poder exercidas sobre a reescritura, chamadas de patronagem. Ela tanto encoraja quanto impede a escrita, a leitura ou a reescritura de uma obra, dependendo de seus propósitos, podendo ser exercida por pessoas, organizações, editoras e pela mídia e, por vezes, ter como cúmplice a crítica, que censura e ameniza elementos nos textos que vão contra a ideologia dominante para publicá-los. O reescritor, por sua vez, tem a opção de seguir ou não o sistema, podendo reprimir ou distorcer o material que lhe foi originalmente 
dado (LEFÈVERE, 2007, p.12-35). Desse modo, as adaptações possuem carga evolutiva, com base no original, mas moldando-se em favor de sua recepção.

Nesse contexto, os reescritores devem manipular os originais até certo ponto para que eles sejam adequados às correntes ideológicas e poetológicas dominantes. Entretanto, eles devem ter uma atenção especial com quem, por que, sob quais circunstâncias e para que público a reescritura será realizada (LEFÈVERE, 1992)

Convém lembrar que apesar de Lefèvere voltar suas ideias para textos intra e intertextuais, o conceito de reescritura pode ser transferido também para questões intersemióticas, já que contemplam, como reescritura, adaptações da literatura para o teatro, o cinema, além de textos facilitados, resumos, etc.

Roman Jakobson (1995) foi o primeiro a citar esse fenômeno, ao postular que existem três espécies de tradução: a intralingual, conhecida também como reformulação, a interlingual, exercida entre idiomas, e a intersemiótica, responsável pela interpretação dos signos linguísticos por meio de sistemas de signos não linguísticos. Para ele, o simples processo de comunicação já envolve tradução pelo fato de o receptor ter de decodificar signos linguísticos do emissor.

De acordo com Oustinoff, o mérito de Jakobson está em ter promovido o fenômeno da tradução ao incitar, indiretamente, o questionamento sobre toda tradução ser intersemiótica: se o sentido de um signo decorre de sua tradução por um novo signo, "pouco importa que ele seja visual (língua escrita ou "língua de sinais"), fonética (língua oral), tátil (alfabeto braile) etc., isto é, ele é resultante de vários sistemas de signos ao mesmo tempo" (OUSTINOFF, 2011, p.24).

À luz do pensamento benjaminiano, Plaza (2003, p.10-12) trabalha a ideia de tradução intersemiótica como forma. Ela está além do significado encontrado na literatura, que procura a manutenção de um mesmo significado por meio de novos significantes restritos ao código verbal. O que se obtém desse campo é um aparato de mecanismos artísticos e históricos que se instauram em favor da recepção, devendo ser pensado a partir das bases tecnológicas particulares de cada momento histórico. A tradução intersemiótica está ligada a essa 
revolução, ela será realizada aos moldes da imediaticidade da recuperação da informação que, cada vez mais, se faz análoga ao cérebro humano. De acordo com o autor:

\begin{abstract}
Tradução como prática crítico-criativa na historicidade dos meios de produção e reprodução, como leitura, como metacriação, como ação sobre estruturas eventos, como diálogo de signos, como síntese e reescritura da história. Quer dizer: como pensamento em signos, como trânsito dos sentidos, como transcriação de formas na historicidade. (PLAZA, 2003 p.14)
\end{abstract}

Gerzymisch-Arbogas (2005) acredita que a evolução das tecnologias transformou a tradução em uma atividade multidimensional, polissemiótica. As inovações transformaram por completo as dimensões do processo de tradução, abrangendo vários formatos e a coexistência de inúmeras modalidades comunicativas envolvendo signos verbais e não verbais.

Sob esse viés, pensa-se a tradução intersemiótica sob a perspectiva audiovisual (TAV), que abarca, principalmente, dublagem, legendagem e audiodescrição. Se a atividade tradutória consiste em um trabalho complexo, que há tempos promove estudos nessa área, o anexo dessa modalidade como tradução suscita novas discussões relacionadas às particularidades e exigências de seu meio.

Seu lugar nos Estudos da Tradução está ligado, também, à sua coexistência com os meios tecnológicos, que foram, pouco a pouco, surgindo com a globalização. De acordo com Chorão (2013, p.6), essa evolução veio para desestabilizar a ideia tradicional de texto. O texto como objeto audiovisual aparece como realidade aberta, polimórfica e multimodal, características que singularizam a tradução intersemiótica nos Estudos da Tradução. Sendo assim, pode-se dizer que ela os favorece academicamente e, ao mesmo tempo, promove maior visibilidade, havendo benefício mútuo.

Sobre a tradução audiovisual, Yves Gambier (2003, p. 172-177) explica que, no final dos anos 1980, com a popularidade do VHS, a tradução de filmes passou a se intensificar. O termo passou por várias modificações, como screen translation, multimedia translation até chegar na nomenclatura atual, que reflete suas várias modalidades, como dublagem, interpretação consecutiva, interpretação simultânea, legendagem, interpretação de sinais, 
voice-over, closed caption, tradução de roteiro, audiodescrição, tradução simultânea, produção multilinguística, etc.

Percebe-se que muitos dos tipos de TAV citados não necessariamente podem ser classificados como audiovisuais. Díaz-Cintas esclarece que esse meio engloba tudo em que há um sinal acústico e um visual, não importando o local de transmissão. Ele explica que:

\begin{abstract}
Na sua acepção primária, a TAV foi usada para encapsular práticas de tradução diferentes usadas na mídia audiovisual - cinema, televisão, VHS — nas quais há a transferência de uma língua-fonte para uma língua-meta. A dublagem e a legendagem são as mais populares na profissão e as mais conhecidas pelo público, mas há também outras tais como voice-over, dublagem parcial, narração e interpretação. A tradução para o espetáculo ao vivo foi adicionada a essa taxonomia num estágio posterior e foi assim que a supra-legendagem [surtitling] para a ópera e o teatro também foi incluída. A mudança de língua que acontece em todos esses casos foi um fator decisivo para nomear essas práticas como tradução (DÍAZ-CINTAS, 2005, p. 4).
\end{abstract}

Ele acrescenta que a TAV, em termos numéricos, tende a ser a mais importante, pois tem facilidade em alcançar maior número de pessoas, mas apresenta quantidade reduzida de estudos. Para ele, um dos grandes motivos da relutância da aceitação da TAV nos Estudos da Tradução é que os códigos utilizados, imagem e som, obrigam à síntese de informações, levando essa terminologia a ser vista como uma adaptação (DÍAZ-CINTAS, 2007, p.9-11).

Com maior flexibilidade associada ao termo tradução e devido à crescente popularidade da TAV, o autor observa a diminuição na resistência de sua inclusão nos Estudos da Tradução, destacando os estudos de Jakobson como primordiais para sua aceitação. Essa foi uma mudança necessária, já que esses modos de tradução quebram os paradigmas da tradução fechada, tradicional. Assim, ela é vista de modo mais maleável, heterogêneo, que acompanha a natureza mutável da prática (DÍAZ-CINTAS, 2007, p. 10).

As práticas audiovisuais podem ser vistas como tradução quando esta for considerada como um conjunto de estratégias que expandem a noção de texto para outros sistemas semióticos, igualmente construtores de significados (GAMBIER, 2003). Portanto, elas devem ser analisadas a partir de sua potencialidade para criar sentidos. Nesta perspectiva, a equivalência deixa de ser vista como estrita, para ser avaliada como relativa. Deixa-se de focar na reprodução da "essência" do texto de origem para se pensar na produção de novos significados no sistema sígnico ao qual se expressa (PLAZA, 2010). 
Embora sem pretender entrar a fundo nos Estudos Descritivos da Tradução, DíazCintas retoma o termo, relacionando-o com a Teoria dos Polissistemas para situar seus estudos. Pensando-se na adaptação como uma tradução audiovisual, mais precisamente, adaptação cinematográfica, é interessante pontuar como ela se insere em algumas vertentes dessa linha de estudo.

O conceito de Polissistema, quando relacionado a filmes, é analisado como produto original e as traduções que se fazem dele (dublagem e legendagem). Esse método permite aferir o processo tradutório como produto do "polissistema alvo", que se molda, de certa forma, à nova cultura. De modo favorável, ele dispensa a ideia de tradução como cópia inferior em relação a um original superior, colocando-a no mesmo nível dos filmes nacionais o que, consequentemente, possibilita a crítica de conceitos socioculturais e permite que se amplie o horizonte de pesquisas desta área em diversos países simultaneamente. Muitos dos trabalhos de TAV estão sendo publicados como estudos cinematográficos, o que permite maior prestígio e visibilidade aos Estudos da Tradução (DÍAZ-CINTAS, 2004, p.23-24).

Com relação à patronagem de André Levèfere, sobre os poderes exercidos sobre a tradução, que podem promovê-la ou restringi-la, no caso da TAV, seus produtos são mais expostos a fatores comerciais, com o mecenato nos níveis ideológico, econômico e social operando também sobre questões envolvendo censura e legislação cinematográfica (subsídios e licença para dublagem e legendagem). Ele destaca o papel da produção na distribuição internacional do material em diversos países e a adversidade encontrada, muitas vezes, entre as preferências do público e os interesses comerciais (DÍAZ-CINTAS, 2004, p.28).

Esses aspectos são trabalhados minuciosamente durante a criação de uma obra cinematográfica, ou mesmo de uma adaptação de uma obra literária. $\mathrm{O}$ sucesso de bilheteria pelo mundo está relacionado também à recepção e ao tipo de público, bem como à sua influência nas escolhas tradutórias para que se tenha uma tradução que vá ao encontro de hábitos culturais e civilizacionais comuns a várias sociedades. No caso de um filme infantil, tais atributos são somados a questões de adequação à idade e capacidade de compreensão, particularidades estas que serão comentadas no decorrer deste trabalho. 


\subsection{Tradução intersemiótica}

A tradução intersemiótica pode ser chamada de adaptação pelo fato de, na troca de um sistema para outro, haver, necessariamente, novos significantes que, por sua vez, podem implicar novos valores. A Routledge Encyclopedia of Translation Studies (BAKER, 2008, p.5) define dois tipos de adaptação: a local e a global. A adaptação local restringe-se a partes isoladas do texto-fonte e pode ocorrer tanto devido à falta de equivalentes lexicais na língua de chegada, como a não existência de um contexto cultural abordado no texto-fonte. Cintrão e Zavaglia (2008, p.1) explicam que

esse tipo de adaptação é uma técnica localizada, motivada por fatores internos ao texto fonte, que o tradutor pode aplicar a uma unidade de tradução que envolve encontros e assimetrias entre língua e cultura-fonte $v s$. língua e cultura-meta. (CINTRÃO; ZAVAGLIA, 2008, p.1)

Já a adaptação global abrange o texto-fonte como um todo, reformulando-o de acordo com fatores externos a ele e operando mudanças profundas em seu conjunto, a exemplo de mudança de gênero textual, como um romance adaptado para o teatro, ou de público-alvo, como um texto dirigido a adultos adaptado para o público infantil. Um dos procedimentos na tradução global é chamado de "equivalência situacional", que tem como propósito ambientar o texto traduzido em um contexto familiar ao público-alvo. Esse procedimento modifica o cenário sociocultural do texto-fonte e envolve a intervenção do tradutor sobre os sentidos e sobre a sistematização da organização textual (BAKER, 2005, p. 5-7).

Plaza (2003) abre espaço para a adaptação como um diálogo entre signos e reescritura histórica, isso faz com que ela dependa muito mais do repertório do tradutor e suas capacidades cognitivas do que da forma em si. Nessa transcodificação do texto original para a reescrita de um novo, deve haver aproximação entre o repertório simbólico do tradutor e o texto. Ele ressalta a importância de se dar um enfoque diferenciado para o processo de tradução intersemiótica:

Creio que problemas de Tradução Intersemiótica devem ter um tratamento de tipo especial, visto que as questões colocadas por esse tipo de operação tradutora exigem o concurso (ou o trabalho em conjunto) de especialistas nas diversas linguagens. Acho quase impossível que um especialista, cuja prática se processa só em uma determinada área semiótica, possa dar conta da importância que o problema da 
tradução interlinguagens exerce no campo das artes e comunicações contemporâneas (PLAZA, 2003, XII).

É importante observar as relações que ocorrem entre sentidos, meios e códigos envolvidos nessa passagem. A tradução de pensamentos em signos precisa de canais e linguagens que façam um intercâmbio de mensagens entre o homem e o mundo a sua volta. Cada sistema de signos irá constituir-se de acordo com sua especialidade para que possam reproduzir os sentidos das mensagens (SEGALA, 2010, p.29).

Por esse ângulo, a transmissão da mensagem em culturas diferentes será estabelecida não só pela recriação de um diálogo com linguagem acessível/inteligível ao emissor e ao receptor, como também, para que pessoas de sociedades e épocas distintas consigam entender o modo de pensar do outro, é preciso, inicialmente, partir-se de uma temática comum, inerente ao homem, para que a partir dela, possam ser expostos pontos de vista favoráveis ou desaforáveis e até mesmo novas concepções acerca do assunto.

\subsection{Adaptação como processo sociocultural}

As traduções, de modo geral, cada vez mais, têm exercido poder dentro de grupos sociais; ultrapassa-se a perspectiva de tradução como um texto estrangeiro para se chegar a um patamar de disseminador de ideologias de qualquer ordem que causem impacto em massa. A tradução audiovisual, por conseguinte, no caso da indústria cinematográfica, coaduna-se com a celeridade e maior abrangência de espectadores dos meios de comunicação para atuar, simultaneamente, sobre vários tipos de público.

A cultura é um fenômeno compartilhado por indivíduos de um determinado grupo ligado à capacidade de se dar significado às ações e aos acontecimentos a sua volta. Embora dentro de um mesmo contexto, cada grupo constrói sua visão de mundo à sua maneira, a depender da época e do local que está inserido. Desse modo, incorpora-se a noção de que há relações hierárquicas de poder que fazem com que todas as modalidades de transmissão impliquem certo grau de dominação, o que promove não só disseminação de ideologias, como 
também desigualdades e contradições. Isso mostra que a cultura está em constante renovação, seja por dinâmica interna ou por algum tipo de pressão exterior (RICHTER, 2003; THOMAZ, $\mathrm{s} / \mathrm{d})$.

Destarte, obras que têm por objetivo a repercussão internacional tornam-se bestsellers, por vezes, devido ao seu enfoque interculturalista, que pressupõe a interação e integração entre culturas. O interculturalismo depende de diversos fatores, como as diferentes concepções de cultura, hierarquias sociais e econômicas, empecilhos comunicativos e estruturas de políticas governamentais.

Mesmo que haja certa tendência a uma dominância entre culturas, há a possibilidade de uma cultura maioritária ser influenciada por outra minoritária pelo fato de esse evento favorecer o enriquecimento sociocultural, ao incitar o aprimoramento da cidadania e da igualdade de direitos. Essa atuação permite que uma cultura tanto interfira na outra quanto dê margem a novos olhares sobre a sua, em uma abordagem interdisciplinar, sendo necessário, para isso, entender a forma como se dão as mudanças sociais por meio da compreensão de questões relacionadas aos direitos humanos, cidadania, trabalho, saúde e educação.

Com maior poder de acessibilidade, origina-se, também, a interculturalidade interpessoal através dos meios de comunicação, como internet, rádio e televisão. Este último é responsável pela disseminação de visões de mundo que serão acessadas por várias sociedades. Nesse sentido, segundo Raquel Segovia (2009), para se ter uma aceitação por parte da culturaalvo, é necessário que o tradutor, ou aquele que irá produzir um material pensando na comunicação em massa, trabalhe o texto em si com uma abordagem sociocultural, garantindo que a cultura de chegada compreenda o que se criou/recriou a partir da cultura de partida.

Se na leitura literária fatores sociais, ideológicos e históricos influenciam na literatura, a transposição desse texto para um meio semiótico distinto do original carregará o peso dessas decisões tradutórias. No caso de uma adaptação cinematográfica, essas condições serão aliadas ao planejamento de um conteúdo para um público pré-determinado. Neste caso, devese ter em mente que a tradução audiovisual será realizada de acordo com a ideologia a que pertence seu público consumidor, assim, a tradução envolve, também, pressupostos socioculturais, interesses econômicos e comerciais. Outra questão é que não há um tradutor visando um público-alvo para cada idioma, mas sim um mesmo produto pensado por uma equipe de cinema, com diretores para cada setor e um geral visando sua aplicabilidade e aceitabilidade no comércio internacional e, consequentemente, buscando retorno financeiro. 
Deve-se levar em conta, também, que um texto baseado na leitura de outro texto, necessariamente será uma versão a partir da visão de alguém. Isso significa que, em uma adaptação cinematográfica, além de serem necessárias mudanças para adequar a narrativa às restrições do sistema semiótico ao qual ela fará parte, serão utilizados os recursos que transporão o que foi interpretado de um texto-base pelo diretor, um dos motivos pelos quais usualmente há discrepâncias por parte do público sobre a fidelidade da história, tendo em vista que obras literárias, ao contrário das audiovisuais, descrevem a história estimulando a imaginação, o que faz com que cada indivíduo associe e imagine os elementos textuais à sua maneira.

Segundo Umberto Eco (1994), todo texto, independentemente de seu sistema semiótico, é articulado a partir de um leitor-modelo. O texto literário é formulado para que o leitor preencha as lacunas deixadas pela narrativa, enquanto o cinematográfico deve ser decodificado pelo espectador, o que significa que em ambos o texto é criado de modo a prever as ações do leitor-modelo.

Eco (1994) explica que, em um mesmo texto, existe a possibilidade de se identificar códigos direcionados especificamente a um tipo de espectador, o que, consequentemente, restringe o público, e outros que são facilmente compreendidos por qualquer um. O leitormodelo é aquele capaz de decodificar diferentes tipos de signos em um filme e, de certa forma, é idealizado como o público principal que o autor quer atingir, sem excluir os demais da narrativa.

No caso de animações, há inferências textuais tanto para crianças como para adultos, em que o último, por ter uma bagagem mais ampla, estaria decodificando códigos mais elaborados. Com efeito, faz-se relevante o vínculo entre recepção, sentido e interpretação como uma relação negociável no espaço semiótico, na qualidade de significação. Questionase, então, sobre a forma com que algumas imagens estereotipadas agem sobre a formação das crianças, tendo em vista que a culturalização está sujeita a todos os tipos de propagação de conteúdo.

A identidade infantil e suas representações sociais são baseadas nos discursos que enunciam sobre a infância. Por meio da linguagem, criam-se, sistematicamente, a cada época, modelos hegemônicos que fazem com que as narrativas passem a ser vistas como 
responsáveis pela formação dos processos identitários. Parte-se do pressuposto de que somos o que ouvimos e o que contamos, sob a influência de lugares, tempo e vozes. Isso faz com que uma única verdade seja constantemente substituída por verdades constituídas. Estas são consideradas crenças e têm como alvo a análise do processo pelo qual algo se torna verdade (LARROSA, 1996; SILVA, 2007; CECHIN, 2014).

Portanto, a passagem de signos verbais para não verbais carrega consigo certas restrições inerentes a essa troca e também o peso de decisões tradutórias associadas ao público-alvo, contexto social e período em que serão lançados. Nesse sentido, a adaptação deve ser desenvolvida de acordo com o sistema a ser vinculado, estimulando os órgãos emissores e receptores que respondem à sua especialidade, tornando relevantes as relações existentes entre os sentidos, meios e códigos referentes a cada sistema sígnico. (PLAZA, 2003, p.45).

Com relação ao público, deve-se, também, respeitar o tipo, bem como seu grau de assimilação de acordo com sua faixa etária, posto que, o sistema audiovisual, por ter estrutura estética diferente da escrita, que permite a projeção de imagens mentais, funciona de forma diferente ao fazer uso de imagens concretas, exigindo maior cautela sobre a adequação de conteúdo ao público.

Sobre a abordagem com o público infantojuvenil, Foucault (1993) esclarece que devido às relações de poder, os discursos estão subordinados aos controles sociais. Na mente da criança, a educação imagética se faz cada vez mais presente, trazendo ao seu cotidiano o ensino de subjetividades pautadas na união de eventos e personalidades culturais. As representações culturais em uma imagem pictórica são reconhecidas conscientemente por meio do lugar no qual elas se encaixam naquela cultura, o que torna a simulação de determinados modos de agir e pensar legítimos (FOUCAULT, 1993, s/p).

Além dos aspectos já comentados, as decisões a serem tomadas na tradução de uma obra destinada ao público infantojuvenil devem atender, entre outras coisas, às exigências da classificação indicativa, dentro da faixa etária na qual seu público-alvo se encontra. O Guia de Classificação Indicativa (2006) sugere que obras audiovisuais devam ser subdivididas e redirecionadas a um público específico de acordo com a faixa etária a partir do grau de exposição e agravantes, "visando proteger crianças e adolescentes de conteúdos inadequados, 
nocivos ao seu saudável desenvolvimento físico e psíquico, como preconiza o Estatuto da Criança e do Adolescente" (CLASSIFICAÇÃO INDICATIVA: Guia Prático, 2006, p.7).

Deve-se observar que está previsto no Manual da Nova Classificação Indicativa a
influência de indicadores que podem atenuar ou agravar as tendências de indicação
presentes na obra audiovisual, em especial, as que versam sobre a relevância do
conteúdo inadequado para a compreensão da trama, a frequência de exibição do
conteúdo e o modo como a cena foi apresentada (a chamada composição de cena, ou
mise-en-scène, levando-se em consideração enquadramento, recursos de edição,
efeitos especiais, sonorização, comportamento dos personagens, etc.)
(CLASSIFICAÇÃO INDICATIVA: Guia Prático, 2006, p.8).

As estratégias da indústria cinematográfica devem direcionar as narrativas infantojuvenis de maneira que o valores socioculturais sejam passados não explicitamente, mas no decorrer da narrativa durante simulações de cenas cotidianas, com códigos voltados para diferentes faixas etárias, desde que seguindo os padrões de atenuantes estabelecidos para a classificação a qual se pretende criar o filme. Dessa forma, mesmo com cenas de humor voltados para o público adulto, a criança irá absorver somente o que for adequado ao grau de maturidade/fase de desenvolvimento no qual ela se encontra. 


\section{LITERATURA INFANTOJUVENIL}

\subsection{Origem dos contos de fadas e sua repercussão}

O surgimento das histórias infantis ocorreu no final do século XVII com a ascensão da burguesia e a consequente mudança do papel da criança ao ser vista como um adulto em potencial. Não havia distinção entre escrita para adultos e para crianças, e, somente a partir do século XVIII, quando a prática da leitura passou a ser ostensivamente valorizada, constataram-se particularidades, próprias da fase da infância. Neste momento, a literatura modificou-se com o intuito de transmitir os valores de um novo modelo familiar, o burguês, “centrado na valorização da vida doméstica, fundada no casamento e na educação de herdeiros" (SILVA; BARROS; NASCIMENTO, 2012, p.4-5).

A França, país mais influente e refinado da Europa na época, trouxe a noção de civilité, uma série de normas de conduta que tinham enfoque na repressão sexual, no discurso refinado e nas boas maneiras e, com isso, houve maior preocupação com as crianças, principalmente, as das classes mais altas (CANTON, 2005a, p.8-12).

Partindo-se dessa concepção, Charles Perrault (1628 - 1703) foi o primeiro a criar um livro de contos de fadas, coletando e adaptando narrativas folclóricas orais contadas pelo povo e adequando-as ao público da corte do rei Luís XIV. Embora escrevesse para adultos, foi com a publicação de obras infantis que ele obteve destaque. Ainda que existam tais circunstâncias em suas obras, o autor eliminou "o quanto pôde as passagens obscenas ou repugnantes, como incesto, canibalismo e sexo grupal" (FARIAS; RUBIO, 2012, p.2) e passou a trabalhar com enredos voltados ao público infantil finalizados com lições de moral.

Essas lições de civilidade determinadas pela época dão a Perrault a oportunidade de, por meio de seu senso de humor sutil e refinado e do domínio da escrita, apoiar a aristocracia de Luís XIV, e, por vezes, criticá-la em seus exageros. Com o tempo, os contos de fada tornaram-se tão populares que peças de teatro, livros, saraus e traduções, feitas a partir de adaptações de manuscritos italianos e contos orientais, viraram o novo modismo na França, 
estimulando o surgimento de novos autores que se basearam nas tradições populares, como os irmãos Grimm, Hans Christian Andersen e outros.

Esses autores trazem alguns exemplos de histórias com representações sociais, se não por meio do que se ouviu falar, pela própria experiência de vida, como no caso de Andersen. Segundo a autora Kátia Canton (2005b, p.7), cada versão de um mesmo conto incorpora valores universais, pertencentes ao senso-comum, somados a valores referentes à história e ao contexto do autor que a escreveu ou transcreveu. Por isso, nenhum conto pode ser considerado atemporal.

Tais valores universais são o resultado de um conjunto de normas decorrentes de mudanças sísmicas na história mundial. Ao longo do tempo, em cada período existiu um cenário de prosperidade econômica, materialista e um aumento do lazer que permitia o luxo do pensamento e da experimentação. Isso fez com que padrões e normas aceitos fossem questionados a ponto de se gerar novas ideias, crenças e modelos de comportamento, tendo como resultado, em cada um deles, a redescoberta da personalidade, da individualidade, do autoconhecimento e da autorrealização (RICHARDS, 1993, p.13).

É por meio desta reforma dos contos de fadas que, gradativamente, adequa-se ao pensamento contemporâneo ocidental, que se dará a discussão do próximo tópico para ser posteriormente aplicada à análise do livro em questão, sem desconsiderar a importância dos contos de fadas tradicionais no desenvolvimento da criança.

\subsection{Conto de fadas tradicional $x$ contemporâneo}

Conto de fadas é o nome dado ao desenvolvimento narrativo que, a partir de um dano ou uma carência, desenvolve-se uma motivação, criando-se uma sequência. A palavra "conto", originária do latim, remete a duas linhas simultaneamente, a da oralidade e a da ficcionalidade. Ele nada mais é do que um relato que faz uso do maravilhoso para entreter e verbalizar problemas humanos (BARBOSA, 1991, s/p). 
Desde sua origem, o conto de fadas apresenta-se como instrumento de comunicação suscetível a alterações, adaptando-se à cultura e aos costumes de cada época, como em um diálogo contínuo entre passado e presente. As modificações realizadas em suas histórias ocorreram paralelamente às transformações socioculturais, sendo incorporadas interdisciplinarmente em cada cultura (CANTON, 1994, p.59). Ainda que recontado de diversas maneiras, com supressões e acréscimos ocorrendo naturalmente, foi constatada a constante presença de alguns elementos essenciais para transmissão de seu efeito moral, como o conteúdo social, simulações interpessoais e estrutura narrativa.

Ao notar tais incidências, o folclorista soviético Vladimir I. Propp, em seu livro Morfologias do Conto Maravilhoso (1928), fez um amplo estudo com 100 contos russos de magia, elencando-os de acordo com as similaridades dos esquemas narrativos. Seu trabalho causou alvoroço entre os folcloristas, quando, em 1958, a partir da tradução do russo para a língua inglesa, percebeu-se que havia a mesma ocorrência entre contos de vários povos que muito dificilmente teriam tido contato entre si. Ele constatou que há um entrelaçamento sutil entre os enredos dos contos maravilhosos, neste caso, os contos de fadas, que dificulta a precisão de uma divisão objetiva, sendo apenas uma aproximação. "Onde um pesquisador vê um enredo novo, outro verá uma variante, e vice-versa” (PROPP, 1984, p. 9-12).

Grande parte dessas narrativas resultam de temas comuns a várias culturas sobre o que se considera problemas humanos universais e suas soluções desejáveis. Eles vão, pouco a pouco, sendo moldados pelo consenso de várias gerações de pessoas e, com isso, pode-se afirmar que o sucesso dos contos de fadas provém da presença constante desses conteúdos juntamente à satisfação de exigências conscientes e inconscientes inerentes ao ser humano. Essas histórias, ao abordarem temas universais de modo realista, mas com tipo de contexto e personagens que não existem no mundo real, conseguem despertar o sentimento de catarse na criança, fazendo-a amar, odiar, ter esperança, medo e desejos junto com o protagonista, sem, de fato, imaginar-se na história (BETTELHEIM, 1980, p.36 e 64).

Essas narrativas atuam não só de modo terapêutico, mas também na estimulação do repertório de soluções adaptativas de conflitos, motivações, transmissões de valores e entendimento de sentimentos (MONACI, 1990). Elas obtêm destaque entre as histórias infantis pelo uso recorrente de um núcleo problemático existencial, em que o herói ou a heroína sai em busca de autoconhecimento e realização pessoal. De acordo com Khéde, esses 
personagens, durante muito tempo, mantiveram-se dentro de estereótipos preconcebidos sobre papeis sociais relacionados à raça, gênero e classes sociais:

[...] Príncipes e princesas são personagens mais predispostos às aventuras. Os primeiros desempenham papéis ativos, heroicos e transgressores, servindo, muitas vezes, como intermediários, num resgate. As princesas são caracterizadas pelos atributos femininos que marcam a passividade e a sua função social como objeto do prazer e da organização familiar. Belas, virtuosas, honestas e piedosas, elas mereceram, como prêmio, o seu príncipe encantado [...] (KHÉDE, 1990, p. 33)

Sendo um gênero, inicialmente, compartilhado por adultos e crianças e posteriormente modificado para o público infantil, quando se descobriu o papel da criança na sociedade, a literatura infantojuvenil tornou-se o único gênero literário constituído a partir do leitor. Partese da perspectiva sobre o que é infância no geral para se delimitar como caráter político e ideológico questões referentes à educação, censura e doutrinação. Para se entender um pouco melhor essa relação entre texto e leitor e o redirecionamento de uma obra para um público específico, é necessário, primeiramente, entender-se como funcionam os estudos relacionados à recepção.

Os teóricos de Constança, Wolfgang Iser (1926-2007) e Hans Robert Jauss (19211997) aprofundaram-se em estudos pertinentes à leitura literária e sua relação com o leitor. Ambos referiram em suas fontes V. Chklovski, B. Tomachevski, Iúri Lótman, R. Jakobson, P. Bogatyrev e, sobretudo, Jan Mukarovsky. Tais autores traziam o conceito de arte como procedimento, estranhamento e paródia, uma vez que se enquadravam na relação com o espectador/leitor. A recepção de uma obra se faz por meio de um fenômeno coletivo, manifestado pelas interpretações singulares ou conjuntas de práticas de leitura de agenciamentos históricos sobre textos e autores.

Sobre a Estética da Recepção, Jauss (1994, p. 39) afirma que além de proporcionar identificação pela rememoração de fatos da vida do leitor, ela pode transmitir conhecimento antecipando uma experiência futura e respostas a perguntas ainda não elaboradas, fatos estes que emergem a partir da literatura engendrando uma reorganização do mundo do leitor.

Como explica Mostaço (2009, p.63) o estudo de Jauss deu estudo deu origem a quatro eixos de investigação. O primeiro propõe que uma obra de arte possa viver e reviver através da percepção contemporânea, sendo ela singularmente histórica. O segundo é que existe uma presunção sobre o autor e os efeitos de sua obra, sendo louváveis aqueles que quebram esse 
paradigma. O terceiro é que esses padrões podem ser criados de acordo com seu tempo, podendo-se rastrear as reações e o que é produzido pela crítica, evidenciando valores e tensões sócio-ideológicas. O quarto é que qualquer que seja a época, a hermenêutica será o discurso interpretativo mais importante para a realização da tarefa.

Esses eixos envolvem procedimentos de investigação por meio de três fases concomitantes da experiência estética que levam à apreensão da obra e à dialogia entre o artista e o espectador: poiesis, aisthesis e katharsis (MOSTAÇO, 2009, p.63).

A poiesis resulta no prazer que sentimos com a obra como forma de apropriação do mundo exterior. É quando se chega a uma plenitude por meio de um conhecimento mais profundo do que aquele infundido pela ciência. A aisthesis implica o reconhecimento perceptivo (MOSTAÇO, 2009, p. 67). Esse ângulo inclui a capacidade de renovar a percepção das coisas, geralmente, enfraquecida pelo dia-a-dia (FIGURELLI, 1988, p.269).

A katharsis liberta o espectador dos vínculos cotidianos e situa-o em um estado de liberdade estética (FIGURELLI, 1988, p.269). Ocorre a liberação da psique ou uma mediação que alivia o sujeito das apreensões das normas de ação e julgamentos, acima das implicações do senso comum.

Ao pensar no contexto de recepção, teóricos de Constança limitaram a pluralidade das três fases ao dividir a função da literatura em dois aspectos. O primeiro é a emancipação, em que a finalidade e o efeito da arte articulam um novo universo sensorial; e o segundo é o de horizonte de expectativas, em que ocorre a soma de códigos, preceitos, experiências sociais e hábitos, ao passo que, mesmo propostas estéticas que almejam o estranhamento, partem do plano da experiência, de uma identificação inicial. Isso significa que a literatura dialoga com os saberes prévios do leitor, que determina a recepção, e o conduz a determinadas posturas emocionais, antecipando o horizonte da compreensão. Dessa forma, a recepção é um fato social e histórico, sendo as reações individuais parte de uma ampla leitura a qual o homem está inserido e com isso, expectativas são construídas socialmente a partir das normas estéticas e ideológicas de determinada época, sendo o horizonte de expectativas responsável pela primeira reação do leitor à obra (SANTOS, 2011, p.83). 
No ato da leitura ocorrem relações de intertextualidade, não apenas entre o texto atual e os anteriores, mas também com seu inconsciente, que influencia na construção de sentido do texto. Sendo assim, a Estética da Recepção é uma teoria que apresenta pressupostos paralelos ao estudo da Sociologia da Leitura e das alegorias. As alegorias expõem um pensamento de representação figurativa ou de duplo sentido, que adiciona um novo significado ao literal, muitas vezes, induzido por um saber extratextual. A sociologia da leitura investiga os fatores, ou mediadores, que podem conduzir o leitor a ler determinada obra, como contexto históricosocial e o meio afetivo, social e cultural.

Wolfgang Iser, por sua vez, centraliza seus estudos nos mecanismos de composição textual e seus possíveis efeitos no ato individual da leitura. Para ele, a leitura é uma forma de ativação da consciência individual que irá incidir na investigação de significados no texto, possibilitando ao leitor concretizar a obra por meio de diversas interpretações. Portanto, a qualidade estética está na forma como o texto é organizado, propiciando ao leitor experiências reais.

Iser também conceituou o leitor implícito, ente textual responsável pela condução da leitura ao emergir de estruturas que reivindicam sua participação. Apesar de os princípios de seleção serem individuais, esta perspectiva tem como objetivo assumir caráter instrutivo. Como esse leitor não possui existência real, um ponto comum de referências é somente imaginado, e assim, o tipo de leitor é delimitado na estrutura.

Esse conceito de leitor implícito de Iser diferencia-se do leitor-modelo de Eco, pois no primeiro há uma estrutura textual que prevê sua presença sem necessariamente defini-lo, ao passo que o segundo, como figura real, tem possibilidade de ler um texto de diversas formas, sem uma regra que de fato determine sua interpretação, sendo o texto um abrigo para suas aspirações, as quais podem fazer parte do mundo exterior ao texto ou ser provocadas por ele próprio (DÉA, 2005, p.36).

Na literatura infantojuvenil é particularmente mais difícil se delinear um público específico a ser seguido justamente por sua nomenclatura abarcar mais de uma faixa etária. Essa imprecisão se dá pelo fato de haver pouco consenso sobre a definição exata do período da infância. Segundo O'Sullivan (2003, p.199), a natureza heterogênea na comunicação dessa literatura é resultado da criação de um adulto implícito que a partir de seus pressupostos 
culturais pressupõe sobre o que poderiam ser os interesses, as inclinações e as capacidades de um leitor implícito de acordo com seu estágio de desenvolvimento.

Para Zohar Shavit (1986, p.63-66), a fraca autoimagem do sistema literário infantil, resultado desta imprecisão em sua nomenclatura, impõe, entre outros aspectos, a escrita simultânea para crianças e adultos. Essa delimitação pode ocorrer ao dirigir-se diretamente ao público adulto e usar a criança como pretexto, modalidade típica do sistema canonizado, ou, como exceção, o excluindo totalmente, típica daqueles pertencentes ao sistema não canonizado. Tal ambivalência faz com que essa literatura pertença simultaneamente a mais de um sistema literário, o que consequentemente, traz diferentes perspectivas a depender do grupo de leitores.

O costume do uso de uma linguagem mais elaborada destinada propriamente ao público adulto, hoje em dia, com a criança cada vez mais consciente dos acontecimentos do mundo, seja pelo fenômeno da globalização ou pelos novos métodos de ensino nas escolas, redireciona-se também a esse novo tipo de leitor, que passa a acompanhar melhor as críticas e inferências a outros textos e assuntos. Por isso, ainda que muito do conteúdo tenha sido suprimido devido à inadequação de exposição de práticas adultas às histórias infantis, a adaptação do conto de fadas tradicional para o contemporâneo sofreu alterações de modo a trazer à criança mais responsabilidade sobre a trama.

As novas histórias exigem maior participação do leitor ao passo que sua estrutura, muitas vezes, deixa de ser linear, tornando-se fragmentada. O leitor então deve preencher os silêncios deixados no texto a partir de suas experiências e seu repertório de leituras. Ao invés de oferecer uma solução com respostas fechadas, há uma predominância de enredos que proporcionam a oportunidade de se resolver os contratempos, e, neste caso, a participação do narrador se faz mais importante. Este, por sua vez, em uma linguagem mais coloquial, mais acessível à criança, perde a tradicionalidade narrativa de onipotência/onisciência e passa a assumir outros pontos de vista como personagem e, simulando uma câmera cinematográfica, coloca o leitor dentro da trama (RICHE, 1999, p. 132-134).

A forma como os contos de fadas contemporâneos transcendeu a tradicionalidade, que perdurou por centenas de anos e ainda habitam nossas memórias de infância, está relacionada à sua produção e recepção. A intertextualidade com os contos antigos remete à tendência de a 
literatura infantojuvenil redirecionar seus ensinamentos de modo a assumir pontos de vista mais atuais na narrativa e personagens com novas posições sociais, em uma revalorização de antigos conceitos em um contexto mais atual. Nessa perspectiva, há o estímulo da desconstrução dos estereótipos comportamentais que costumavam fazer parte do universo literário infantil para que os enredos acompanhem as inovações na sociedade, passando-se o foco, cada vez mais, para a crítica social.

Segundo Woodward (2007, p. 25),

[...] as identidades que são construídas pela cultura são contestadas sob formas particulares do mundo contemporâneo - num mundo que se pode chamar de póscolonial. Este é um período histórico caracterizado, entretanto, pelo colapso das velhas certezas e pela produção de novas formas de posicionamento [...] (WOODWARD, 2007, p. 25).

Essas narrativas abrem espaço para que os novos contadores assimilem referências prévias e as transformem com soluções que correspondam ao seu tempo. Ainda há personagens antigos como reis, rainhas, súditos e seres místicos, mas, desta vez, questionamse valores e as possíveis relações em uma sociedade. Não há enquadramento dos personagens nos papéis sociais pré-estabelecidos na medida em que há uma revolta ou uma atitude contrária da que se espera, posicionando-os de modo mais condizente com a realidade.

Essa literatura propõe, dentro de sua estrutura, que se trabalhe com o texto, pelo ponto de vista da intertextualidade e da releitura, de modo a se obter uma herança cultural. Esse processo de recepção se completa com a assimilação de tudo que já foi vivido e aprendido com o texto em si.

O método recepcional baseia-se na ideia de que a obra literária é um cruzamento de concepções que sobre ela se fizeram e se fazem nos vários contextos históricos em que foi e é lida. Assim sendo, uma obra é atualizada a cada leitura, isso porque sua recepção já vem concebida na própria estrutura. No momento de sua produção, o leitor já está presente, pois o autor, ao escrever o texto, leva em conta o tipo de receptor que tem em vista, criando, assim, o sujeito possível a quem ele pretende falar, com quem quer conversar (AGUIAR et al, 2001, p.148).

Como em um fenômeno de anexação, o leitor contemporâneo busca em seus livros a identificação, consciente ou não, de princípios. Há um processo de solidariedade semiótica 
realizada entre leitor e livro, em que, naturalmente, ocorre a recriação de histórias ao se adicionar ou subtrair opiniões, preparando o público infantil para se tornar adultos mais reflexivos e exigentes. A ênfase no receptor é, por conseguinte, a característica que melhor define a contemporaneidade da obra. Tendo como objetivo despertar no leitor a consciência das mudanças no mundo, a obra é então conduzida em direção ao amadurecimento de seu olhar sobre a sociedade (COELHO, 2000).

\subsection{Literatura humanizadora}

Inúmeras vezes, nos deparamos com histórias que tentam explicar o aparecimento e a razão de ser do mundo físico e da sociedade. Tais tentativas expõem a relação entre a imaginação explicativa, que é a do cientista, e a fantástica/ficcional/poética, que é a do escritor. Para Bachelard (1988, citado por CANDIDO, 1972), somente o devaneio tem o papel da verdadeira imaginação, pura, criada por estímulos da realidade, mas sem a indução da percepção. Isso mostra como a criação literária integra referências da realidade e funciona de modo subconsciente no leitor, já que, a partir de ambivalências, ela age com o impacto da vida e educa como ela (CANDIDO, 1972, p.81-82).

A abordagem de ambivalências suscita duas reações: a fascinação por sua força humanizadora e o repúdio por sua perversão e subversão. Ao invés de a literatura funcionar como manual de boa conduta, a sociedade a seleciona de acordo com o assunto que for mais adaptável aos seus fins em determinado momento, razão pela qual, temas banidos são frequentemente retomados. Paradoxalmente, há o conflito entre a literatura convencional e sua força indiscriminada de iniciação na vida, o que faz com que ela nem corrompa nem edifique, mas humanize o homem porque o faz viver (CANDIDO, 1972, p.83-85).

A necessidade de ficção se manifesta pela construção de um ideal, pela esperança, pelo devaneio. Em resposta, a literatura intervém como função psicológica e cria sistematicamente a fantasia a partir da realidade como: "fenômeno natural, paisagem, sentimento, fato, desejo de explicação, costumes, problemas humanos, etc.". Ela opera como ato social na medida em 
que é desenvolvida, também, por experiências humanas, despertando o interesse pelos elementos contextuais. Com isso, a noção de valor se faz inerente à preocupação do homem com a própria identidade e destino (CANDIDO, 1972, p.77-81).

No caso da formação da criança, as obras apresentam caráter ético-didático, com mensagens específicas, adequadas àquelas desejadas pelo narrador, podendo ser intensificadas, quando necessário. As histórias propiciam o desenvolvimento da atenção, do raciocínio, de noções de ética e moral, da imaginação, da criatividade, do crescimento intelectual e estético e da transmissão de valores para as crianças, por isso a importância de garantir a vivência das narrativas desde os primeiros anos de vida (FARIAS; RUBIO, 2012, p.4-7).

Segundo Vigotsky (1992, p.128-129 apud FARIAS; RUBIO, 2012), a imaginação tende a afastar a consciência da realidade, o que é essencial para a criação de processos cada vez mais complexos, enriquecendo a capacidade cognitiva (FARIAS; RUBIO, 2012, p.7-8). Ao entrar no mundo da imaginação, a criança desempenha vários papéis e elabora inúmeras hipóteses para solucionar seus problemas, pensando como um adulto e buscando alternativas para além da sua realidade (FARIAS; RUBIO, 2012, 9-10). Assim, os contos de fadas agem no imaginário infantil pelas possibilidades interpretativas e identificatórias e pelos significantes linguísticos (COUTO; CAMPOS, 2009, p.5).

O psicanalista Bruno Bettelheim (1980, p.4-5), a partir de sua experiência com crianças seriamente perturbadas, aponta que a literatura destinada ao desenvolvimento da mente e da personalidade da criança é superficial e não tem resolvido os problemas interiores pertencentes às etapas da infância. Histórias pouco significativas não geram a confiança e o autoconhecimento necessários para que seu intelecto se desenvolva e, é pelo reconhecimento de suas próprias angústias e aspirações que a criança irá estimular a imaginação para solucionar problemas internos.

Antigamente, alguns compiladores acrescentaram diretrizes comportamentais ao final das histórias, "contudo, essas conclusões morais não se harmonizavam com os eventos na história e vez por outra não ofereciam nada além de uma oportunidade para um comentário social aleatório e digressões sobre caráter". Tal experimento foi motivo de frustração, já que 
crianças costumam aprender pela observação ou pela experiência pessoal (TATAR, 2004, p.12).

Tudo deve ocorrer no universo da história de acordo com o esperado. Há uma ética do acontecimento, ou uma moral ingênua, em que a ordem é afetiva e o efeito do conto de fadas é produzido em dois sentidos: o trágico e a abolição dele. Para a realização da narrativa, a história deve ser iniciada com estados e incidentes considerados injustos, para que o foco recaia sobre os acontecimentos e não sobre o ajuste de contas, sendo a justiça o fator mais importante, e não a vingança (JOLLES, 1976, p.198-201).

\footnotetext{
Ao contrário do que acontece em muitas estórias infantis modernas, nos contos de fadas o mal é tão onipresente quanto a virtude. Em praticamente todo conto de fadas o bem e o mal recebem corpo na forma de algumas figuras e de suas ações, já que bem e mal são onipresentes na vida e as propensões para ambos estão presentes em todo homem. É esta dualidade que coloca o problema moral e requisita a luta para resolvê-lo (BETTELHEIM, 1980, p.7).
}

O fato de o personagem mal sempre sofrer consequências traz a noção de que o crime não compensa e de que tal atitude não deve ser reproduzida. Por outro lado, a identificação com o protagonista faz com que os conflitos interiores do personagem incidam sobre a vida do leitor/ouvinte. Assim, a moralidade constrói-se inconscientemente, por meio de devaneios conscientes, resultando no controle da situação por parte da criança (BETTELHEIM, 1980, p.7-8).

3.4 A obra literária: The Tale of Despereaux: being the story of a mouse, a princess, some soup, and a spool of thread

A obra The Tale of Despereaux: Being the Story of a Mouse, a Princess, Some Soup and a Spool of Thread (2003) é dividida em 4 livros, mostrando a perspectiva dos três protagonistas; na ordem: Despereaux, Chiaroscuro, Miggery Sow, e por fim, todos atuando juntos.

Aproveitando a divisão estratégica da narrativa, será feita agora uma análise do livro com base na discussão do conto de fadas tradicional x contemporâneo. Nesse primeiro 
momento, serão expostos, destacando-se a partir do enredo, apenas os eventos que mais surtiram efeito sobre a construção da personalidade dos personagens principais de modo a terse um entrelaçamento das histórias no final.

Como já mencionado, o desenrolar da narrativa mostra suas histórias de vida, explicitando por que eles têm certas atitudes, por vezes, ruins. Os acontecimentos que os cercam aparecem como situações trágicas e, de certa forma, traumáticas, são comumente encontrados no conto de fadas tradicional.

Tendo-se essa noção, na última parte desse trabalho, serão apontadas as diferenças e semelhanças entre livro e animação, comparando-se a análise aqui realizada com os planos cinematográficos para que se possa inferir quais foram as mudanças no que se refere a perspectivas socioculturais.

\subsubsection{Enredo}

Livro I: A história se inicia com o nascimento de Despereaux, o último e único sobrevivente de sua ninhada. Antes mesmo de olhar para ele, sua mãe, Antoinette, reclama de seu esforço em vão. O camundongo tem algumas particularidades: ter orelhas grandes, ser bem pequeno, nascer com os olhos abertos e estar sempre doente, ao contrário dos outros irmãos mais velhos. Além disso, com o tempo, ao invés de se interessar por comida e temer o mundo afora, vê beleza em cada aspecto da vida. Um dia, ao acompanhar os irmãos para rasgar papel, começa a ler parte de uma história sobre um cavaleiro que salva uma princesa. Sem esquecer a bela história, do outro lado do castelo, o camundongo se encanta ao escutar o rei tocando violão e, ao se aproximar, quebra a regra mais importante da comunidade: nunca falar com humanos. Despereaux, instantaneamente, se apaixona pela filha do rei, Princesa Pea. Seu irmão, Furlough, o vê e retorna para casa para denunciá-lo ao seu pai, Lester. O rei, traumatizado com um incidente envolvendo ratazanas, exige que o camundongo vá embora do reino e, quando ele encontra seu pai, ele, junto ao conselho, o sentencia a ser comido pelas 
ratazanas no calabouço. Chegando lá, é salvo da morte pelo carcereiro em troca de contar-lhe uma história.

Livro II: Chiaroscuro é uma ratazana que, diferentemente dos outros de sua comunidade, apaixona-se pela luz. Morando no calabouço, ele é orientado por seu amigo Botticelli a atormentar o novo prisioneiro. Ele pergunta ao homem a razão de estar preso e se irrita ao saber que ele havia trocado a filha por um pano vermelho, um maço de cigarros e uma galinha. Chiaroscuro rouba o pano e decide subir para o castelo para ter contato com a luz. Lá, fica encantado com a festa da realeza e decide observá-la de cima de um lustre. Ele cai na sopa da rainha que, enojada, engasga-se e morre. Chiaroscuro percebe o desprezo da princesa Pea, e neste momento, seu coração se enche de rancor. Como consequência, sopa e ratazanas são proibidas na cidade.

Livro III: Órfã de mãe e vendida pelo pai, a história de Miggery Sow começa quando um velho, que a pede para chamá-lo de tio, a compra. A garota constantemente apanha do homem, o que a deixa parcialmente surda. Certo dia, seu tio comenta com os guardas do palácio que Miggery é uma de suas posses e então ela é levada ao castelo para ter seu próprio emprego. Sua função passa a ser levar comida ao carcereiro, Gregory, e lá, encontra Chiaroscuro, que a convence de que se ajudá-lo a sequestrar a princesa, poderá ficar no lugar dela.

Livro IV: Depois de contar uma história ao carcereiro, Despereaux escapa do calabouço em uma bandeja de comida que Miggery havia levado a Gregory. Ele é visto por ela e pela cozinheira, que ordena que Miggery o mate, e, ao tentar escapar, seu rabo é cortado pela faca da personagem. Ele passa a noite com dor, pensando em como salvar a princesa e sonhando com um cavaleiro sem face, o que o faz duvidar da existência de um final feliz. Enquanto isso, Chiaroscuro faz Miggery sequestrar Pea e levá-la ao calabouço e, ao chegarem, a ratazana conta que tudo não passava de um plano e ela jamais seria uma princesa. Despereaux consegue uma agulha e corajosamente vai até o calabouço salvar a princesa. Quando encontra Chiaroscuro, o ameaça de morte, mas é impedido por Pea, que perdoa a ratazana por seus atos. Chiaroscuro passa a ter permissão para andar pelo castelo, Miggery se reconcilia com seu pai e Despereaux se torna um grande amigo de Pea; todos se reúnem para comer a sopa à mesa enquanto a família de Despereaux apenas observa, de longe. 


\subsubsection{Análise do livro}

É possível encontrar no conto de fadas contemporâneo a presença de elementos típicos do tradicional, dessa vez, postos em uma nova disposição. Essa proposição de novas leituras ou leituras mais atuais sobre questões essenciais do sujeito sugere a renovação do perfil do leitor, que, se antes aprendia por assimilação subconsciente, agora se coloca como sujeitoativo ao questionar e criticar acontecimentos na narrativa, tomando para si grande parte da responsabilidade do papel formador da literatura infantojuvenil de sujeitos-leitores.

A narrativa The Tale of Despereaux: being the story of a mouse, a princess, some soup, and a spool of thread apresenta diversas críticas com relação às atitudes dos personagens. Um fator comum que conduz tais comportamentos reprováveis é a subserviência a regras infundadas, que fazem com que os personagens, nas três sociedades, sejam contra tudo o que fugir ao que fora estabelecido por lei.

De forma didática, o narrador aparece em certas partes do enredo para mostrar que aquilo que foi dado como certo, por vezes, pode estar errado. Ele adverte durante a história sobre o "mundo real" não ser somente luz.

Essa não é uma bela história. Há violência e crueldade nela. Mas esse tipo de narrativa também tem certo valor. Tudo, como você sabe (tendo vivido neste mundo o suficiente para ter constatado uma ou duas coisas), não é somente luz e ternura (Tradução minha, p.183).

Em diversos excertos, ele faz uso de "choques de realidade", afirmando, mais de uma vez, que o mundo é escuridão, como se quisesse mostrar ao leitor em desenvolvimento um novo olhar sobre a realidade, não somente aquela apresentada a ele por meio de livros com um "felizes para sempre no final". Ele não só enfatiza que o mundo possui conflitos a se resolver, como também instiga o lado discente do leitor ao associar a prática da leitura à luz,

The story is not a pretty one. there is violence in it. And cruelty. But stories that are not pretty have a certain value, too, I suppose. Everything, as you well know (having lived in this world long enough to have figured out a thing or two for yourself), cannot always be sweetness and light (p.183) 
e, em partes da narrativa, utilizar palavras incomuns no vocabulário da criança para que ela procure seu significado no dicionário.

Histórias são luz. Luz é uma preciosidade em um mundo tão sombrio. (Tradução minha, p.81).

Tendo-se essa noção, para se entender a fundo a construção da personalidade dos personagens principais na narrativa, a primeira coisa a se analisar é o nome deles. Bruno Bettelheim (1980) explica que, no conto de fadas tradicional, o fato de, muitas vezes, os personagens terem nomes descritivos (o soldadinho de chumbo), genéricos (João e Maria), incomuns, ou não terem um nome, sugere impessoalidade e até mesmo insignificância, o que traz otimismo e esperança para a criança, pois o fato de os heróis da história parecerem comuns suscita na criança a expectativa de que ela também pode ter seu final feliz. (BETTELHEIM, 1980, p.41).

No livro de Kate DiCamillo, todos eles têm nomes incomuns e descritivos. O modo como foram chamados está ligado tanto à sua aparência quanto à forma como se comportam em sociedade.

Filho de mãe francesa, o nome Despereaux faz alusão ao substantivo francês "désespair", que significa "desespero", somado ao sufixo "eaux”. Em seu nascimento, sua mãe, Antoinette, recebe a notícia de que todos de sua ninhada haviam morrido, menos um. Sem ao menos ver seu filhote, e extremamente pessimista, ao ser questionada sobre qual nome daria, ela responde que, como ele iria morrer como os outros, o nome será Despereaux, representando toda a tristeza e desespero que há no lugar onde vivem.

Despereaux é um camundongo diferente dos cidadãos de sua sociedade. Além de sua aparência física, ele apresenta problemas de saúde, desmaiando frequentemente. Nesta sociedade, os camundongos vão à escola e são ensinados desde o primeiro dia a temer o conhecimento (devem comer páginas de livros ao invés de lê-las), serem medrosos e ariscos, e a regra mais importante: não interagir com humanos. Despereaux, por ter pensamentos contrários e inovadores, é tratado com descaso e escárnio por sua comunidade. 
Fica clara a intenção de se evidenciar que o poder sobre essa comunidade ocorre principalmente pela proibição de qualquer coisa que possa fazê-los perceber que algo está errado. O camundongo sofre discriminação, inicialmente, por suas "deficiências". Essas características físicas marcantes, explicitadas no início da trama como o principal motivo para o rejeitarem, tempos depois, quando ele começa a desenvolver a capacidade de opinar e criticar, tornam-se apenas mais um traço de sua inadequação; agora, suas atitudes e sua falta de "educação" incomodam mais.

Com relação a Chiaroscuro, seu nome, em italiano, significa claro-escuro. Ele, que recebe esse nome por ironia dos pais que, como toda ratazana, odeiam luz, acaba, de fato, sendo um grande admirador dela. Ele passa a ser chamado apenas de Roscuro durante a narrativa e, uma das interpretações para essa transição pode ser o fato de que, apesar de ele não ser originalmente mau, deixa-se levar pelo ódio.

O narrador justifica as atitudes negativas dos protagonistas por meio da elucidação de ocasiões que tenham causado um grande impacto traumático em suas vidas. No caso de Roscuro, o narrador deixa claro o que se passa em seu íntimo no momento em que a ratazana percebe o asco e a raiva de Pea.

Há certos tipos de coração, leitor, que uma vez partidos, jamais se reconstituem. Mas, se isso acontecer, ficarão tortos e assimétricos, como se fossem feitos por um artesão descuidado (Tradução minha, p.116).

Em sua sociedade, as ratazanas são descritas por elas mesmas como seres sujos, mesquinhos, de má índole. As regras sugerem que todos devem ser trapaceiros e ladrões. Roscuro, embora não pareça ser tão diferente dos demais, tem uma particularidade: amar ter contato com a luz. Uma prova de que ele pensa de modo diferente dos demais se evidencia por pequenos momentos de crise de consciência. Na cena em que ele importuna um prisioneiro a mando de Boticelli, líder do grupo, o narrador comenta que Roscuro sabia que Botticelli estava errado em sua forma de pensar, mas o faz mesmo assim para que possa ser liberado para fazer escondido o que realmente gosta: olhar para a luz do sol.

There are those hearts, reader, that never mend again once they are broken. Or if they do mend, they heal themselves in a crooked and lopsided way, as if sewn together by a careless craftsman (p.116). 
Que decepção! Roscuro sabia que Botticelli estava errado. O que ele queria, precisava, não era o pano, mas sim a luz que brilhava atrás dele. Ele queria ser preenchido, inundado, ser cegado novamente pela luz. E, para isso, leitor, a ratazana deveria subir as escadas. [Tradução minha, p.102]

Uma característica do conto de fadas contemporâneo aparece neste personagem ao, de forma sutil, evidenciar-se traços de bondade em sua vilania. Similarmente à personalidade humana, Roscuro erra por não usar a razão. A tentativa de pedir perdão mostra inicialmente seu caráter, mas a forma como Pea o trata cria nele um sentimento crescente de raiva, que o faz querer causar mal à princesa. Como já mencionado, a luz é associada a tudo de bom que há no mundo. $\mathrm{O}$ fato de Roscuro ter empatia por ela, sendo membro de uma sociedade criada para ser má, demonstra sua vontade de ir para o lado do bem.

No caso de Miggery Sow, seu nome é escolhido por seu pai em homenagem a uma porca que ele ganhou como prêmio em uma competição. Seu nome pode ter dois sentidos, "porca miserável" = misery sow ou "alma miserável" = misery soul. Seu significado não é exato, no caso, seria o adjetivo "miserable", sendo as duas conotações plausíveis, pois ela vive grande parte de sua vida cuidando de porcos e sendo negligenciada e menosprezada pelos outros.

Miggery é uma menina que, desde criança, ouve de todos que ninguém se interessa pelo que ela pensa. Mais tarde, sua solidão, somada às surras constantes do homem que a criou, torna seu sonho de ser princesa cada vez mais intenso. Sua capacidade cognitiva é reduzida junto com sua audição. Assim, todos que tentam interagir com ela, perdem a paciência facilmente. Apesar de todo o seu sofrimento, Miggery nunca respondeu ou reagiu a qualquer um que a tivesse feito mal. Sua paciência chega ao limite quando Pea, pessoa idolatrada por ela devido a sua posição social, a trata com desdém. A atitude da menina ao sequestrar a princesa é, de certa forma, amenizada por sua trágica história de vida, o que revela uma perspectiva mais cristã, de absolvição de erros diante dos problemas sofridos.

Mesmo não tendo um livro contando sua história, a Princesa Pea tem grande participação no enredo por fazer parte da construção da personalidade dos outros e ter os

What a disappointment it was! Looking at it, Roscuro knew that Botticelli was wrong. What Roscuro wanted, what he needed was not the cloth, but the light that has shone behind it. He wanted to be filled, flooded, blinded again with light. And for that, reader, that rat knew that he must go upstairs (p.102). 
mesmos tipos de incidentes afetando sua vida. Seu nome tem relação com o conto de fadas "A Princesa e a Ervilha", que conta a história de uma moça que chegou a um reino alegando ser princesa e, como prova de sua majestade, sentiu, embaixo de vários colchões, um grão de ervilha. Um traço marcante na personalidade de Pea é que ela, mesmo triste com todas as adversidades, mantém-se esperançosa e firme como uma verdadeira princesa, ao contrário de seu pai, que anda depressivo e introspectivo pelos cantos do castelo, omisso em relação às suas obrigações reais.

Com relação aos relacionamentos familiares, no que concerne a Despereaux, os pais sempre perceberam sua autenticidade e tentaram mais de uma vez fazê-lo aprender com o irmão que, ao ver Despereaux desobedecer às regras, conta ao pai, membro do conselho, sobre suas atitudes inadequadas. A covardia do pai, Lester, é acentuada principalmente por ser o responsável por determinar o tipo de acusação de Despereaux, ao passo que a mãe faz um teatrinho exagerado para tentar salvar o filho, porém, quando percebe que seu plano não foi bem-sucedido, simplesmente diz "adieu" para Despereaux. O narrador destaca a atitude dos dois para com o próprio filho, fazendo com que o leitor traga tal situação para si:

Leitor, você consegue imaginar seu próprio pai não votando contra o seu envio para um calabouço cheio de ratos? Pode imaginá-lo não dizendo uma palavra em sua defesa? [Tradução minha, p. 44]

Pelo menos, Lester teve a decência de chorar por esse ato de perfídia. Leitor, você sabe o que significa perfídia? Tenho a impressão de que sabe, baseado na pequena cena que acabou de acontecer. Mas você deveria procurar a palavra no dicionário, só para confirmar. [Tradução minha, p. 45]

[...] Você sabe o significado da palavra "adieu”? Esqueça o dicionário. Eu lhe conto. Adieu é adeus em francês. Esta não é uma palavra que você gostaria de ouvir da sua mãe enquanto é levado ao calabouço por dois ratos encapuzados. O que você gostaria de ouvir seria algo do tipo "me leve no lugar dele". Essas são palavras mais reconfortantes. Mas, leitor, não há conforto na palavra adeus, mesmo

Reader, can you imagine your own father not voting against your being sent to the dungeon full of rats? Can you imagine him not saying one word in your defense? (p.44)

At least Lester had the decency to weep at his act of perfidy. Reader, do you know what perfidy means? I have a feeling you do, based on the little scene that has just unfolded here. But you should look up the word in your dictionary, just to be sure. (p.45) 
em francês. Ela é uma palavra que em qualquer linguagem é carregada de tristeza e não promete absolutamente nada. [Tradução minha, p. 65-66]

Indo a julgamento e não alegando inocência, é mandado ao calabouço e, desnorteado por ter não sido defendido pelos pais, Despereaux fica chocado ao perceber que um dos encapuzados que o estão levando para a morte é seu próprio irmão. Ele pede clemência, mas o irmão diz que regras são regras e fala em voz alta, como procedimento, a sentença do condenado: usar uma linha vermelha em volta do pescoço, cor escolhida para representar pena de morte. O narrador chama a atenção para a postura do irmão, retomando o que foi dito sobre seu pai:

Leitor, você lembra da palavra perfídia? Quanto mais nossa história progride, mais a palavra perfídia se torna apropriadada, não acha? Perfídia era certamente a palavra que estava na mente de Despereaux conforme ia sendo guiado para um buraco escuro que dava para o calabouço. [Tradução minha, p. 69]

Essa atitude negativa dos familiares com Despereaux era comumente encontrada em contos de fadas tradicionais. A questão do abandono e da rejeição aconteciam nas tramas como propulsão para que o personagem tido como frágil e incapaz pudesse viver sua desventura e descobrir seu valor. Aqui, o narrador aproveita para mostrar ao leitor que, não importa a razão, não se deve trair a confiança de um filho, mesmo que sob ameaça.

Em circunstâncias típicas dos contos de fadas tradicionais, como simulações de agressão, medo, frustração, abandono, rejeição, rivalidade entre irmãos, relacionamento com os pais, inferioridade, inveja, vingança e esperança, a autora Kate DiCamillo mostra o lado humano dos personagens criando uma série de eventos que interferem na forma como irão reagir na trama.

[...] Do you know the definition of adieu? Don't bother with your dictionary. I will tell you. Adieu is the French word for farewell. "Farewell" is not the word that you would like to hear from your mother as you are being led to the dungeon by two oversize mice in black hoods. Words that you would like to hear are "take me instead. I will go to the dungeon in my son's place." There is a great deal of confort in those words. But reader, there is no confort in the word "farewell", even if you say it in French. "Farewell" is a word that, in any language is full of sorrow. It is a word that promises absolutely nothing. (p.65-66)

Reader, do you recall the word 'perfidy'? As our story progresses, 'perfidy' becomes an ever more appropriate word, doesn't it? "Perfidy" was certainly the word that was in Despereaux's mind as the mice finally approached the narrow, steep stairs that led to the black hole of the dungeon. (p. 69) 
Para que essas complexidades sejam compreendidas pelo leitor como comportamentos aceitáveis ou mesmo dignos de perdão, o narrador faz interrupções para fomentar o pensamento crítico-social no leitor. Cada atitude que vai de encontro ao que se construiu historicamente em nossa sociedade em termos de ética e moral são ressaltados e rejeitados na história em uma tentativa de causar um efeito catártico na criança, que é envolvida pelo narrador nos acontecimentos que mais aborrecem os protagonistas.

Consequentemente, ao contrário do que era idealizado nas histórias infantis de antigamente, em que todos eram ou bons ou maus, os protagonistas desta narrativa são detalhadamente estruturados para que se justifiquem suas atitudes ambivalentes. Neste caso, Estes sentimentos são evidenciados para que se entenda, no decorrer da trama, a mudança de um personagem bom para mau e sua possível redenção.

A atuação do narrador, de modo geral, se dá pela reprovação às ações negativas dos antagonistas com os protagonistas. Por detrás de suas falas, teoricamente relacionadas a relações interpessoais, está a reflexão sobre até que ponto pode chegar uma sociedade em que os sujeitos não têm pensamento crítico, o que o leva a defender os protagonistas, contrariados e desrespeitados por todos os membros dentro de suas comunidades.

O conceito de moral na construção dos contos de fadas não corresponde a um conjunto de normas de comportamento como estamos condicionados a pensar. Aqui, há uma espécie de moral ingênua, em que tudo o que favorece o herói é bom e tudo o que o prejudica é mau. Em outras palavras, esta é uma moral flexível e pragmática, ligada a ações e situações do aquiagora. Embora condenável em termos de sociabilidade, essa circunstância traz à tona fortes conflitos humanos que demonstram que errar é algo naturalmente humano, quando simpatizamos com o personagem (AZEVEDO, 2007, p.3 e 4).

A literatura, sendo parte do fenômeno da linguagem é, por si só, um veículo transmissor de valores e concepções. A liberdade do poder criador do autor contemporâneo é muito mais regrada à medida que se entende o poder da palavra como construtor do real e, assim, a preocupação sobre como narrar se sobrepõe ao que narrar (COELHO, 2000, p.154$155)$. 
O destaque à postura dos pais é algo recorrente nas histórias infantis. Um dos motivos é a facilitação da transmissão do efeito desejado pela utilização de conflitos com personagens que fazem parte do cotidiano do leitor. A criação de Miggery é um pouco mais traumática, ao passo que envolve perdas, violência física e psicológica e abandono. Ela, tratada com descaso por sua mãe, a perde aos seis anos e é vendida pelo pai para um homem que costuma lhe bater. Anos depois, consegue chegar mais perto de seu sonho de ser princesa, indo trabalhar no castelo.

\begin{abstract}
Mig assistiu seu pai indo embora com o pano vermelho balançando atrás dele. Ele abandonou a filha. Leitor, como você já sabe, ele não olhou para trás. Nem uma vez. Você consegue imaginar? Imagina seu próprio pai lhe trocando por um pano, uma galinha e um maço de cigarro? Feche seus olhos, por favor, e pense nisso por um momento. Pronto? Espero que você tenha sentido um arrepio na espinha ao pensar no destino de Mig e como isso teria repercutido em sua própria vida. Coitada de Mig. O que será que aconteceu? Você deve ter tido uma sensação horrivel, mas veja por si mesmo, leitor, é a sua tarefa. [Tradução minha, p. 127]
\end{abstract}

Como trabalho escravo, Miggery é obrigada a limpar o chiqueiro todos os dias e recebe tapões na orelha por qualquer motivo.

\begin{abstract}
Quanto menos ela ouvia, menos ela entendia. Quanto menos entendia, mais errado fazia as coisas. Quanto mais errado fazia as coisas, mais tapões na orelha e assim menos entendia. Chama-se essa situação de círculo vicioso e Miggery estava no centro dele, que é um lugar onde ninguém gostaria de estar, leitor, mas, como você já sabe, ninguém estava preocupado em saber o que Miggery queria [Tradução minha, p. 130]
\end{abstract}

Mig watched her father walking away, the red tablecloth billowing out behind him. He left his daughter. And, reader, as you already know, he did not look back. Not even once. Can you imagine it? Can you imagine your father selling you for a tablecloth, a hen, and a handful of cigarettes? Close your eyes, please, and consider it for just a moment. Done? I hope that the hair on the back of your neck stood up as you thought of Mig's fate and how it would be if it were your own. Poor Mig. What will become of her? You must, frightened though you may be, read on and see for yourself. Reader, it is your duty (p.127)

The less Mig heard, the less she understood, the less she understood, the more things she did wrong; and the more things she did wrong, the more clouts to the ear she received, and the less she heard. This is what is known as a vicius circle and Miggery Sow was right in the center of it. Which is not, reader, where anubody would want to be. But then, as you know, what Miggery Sow wanted had never been of much concern to anyone (p.130). 
$\mathrm{O}$ apelo do narrador ao dizer que espera que o leitor tenha sentido um arrepio na espinha e ao frisar a situação em que Miggery se encontra ao chamá-la de coitada, expõe o caráter socioeducativo da obra. A exposição desses eventos traumáticos direcionados pelo narrador, trazendo para o leitor o que alguém sente quando é menosprezado, serve para que ele mesmo entenda o que não deveria fazer com os outros. De acordo com Novaes Coelho (2000, p. 46), inicialmente, a obra deveria ser marcada por seu adjetivo infantil, pautando-se na essência literária e partindo-se dos interesses da criança como polo condutor. Entretanto, recorrentemente, têm-se prevalecido outros interesses fundamentalmente pedagógicos, tornando essa literatura um instrumento de cunho didático.

Muito disso ocorre como reflexo da herança de contos gerados em sociedades que tinham por objetivo impor valores corretivos e morais na literatura infantil. Com isso, volta-se à discussão para a necessidade de se relacionar o contexto de produção e as convenções sociais à estrutura do gênero em si. Tendo em vista os elementos que permeiam a situação enunciativa, como meio de circulação, locutor, interlocutor, etc., pode-se dizer que a finalidade discursiva do gênero conto de fadas é a disseminação de rupturas sociais e é por meio dela que o enunciado é construído.

Compreende-se que os contos de fadas contemporâneos surgem como respostas aos tradicionais, dando continuidade a eles, como forma de justificar e explicar o que ficou implícito. Isso pode ser exemplificado pela violência presente nos originais, que agora é enfatizada como algo reprovável. Ensina-se a criança a ver as consequências de seus atos.

Um dos motivos para que essa crítica social nos contos de fadas contemporâneos seja mais fundamentada se dá pelo fato de que o contexto social para o qual a obra está sendo criada é bem mais amplo e diversificado do que o daqueles que criavam para um público local.

Mesmo tendo-se o enfoque da trama na ambientação dos personagens em meio a tragédias, a esperança é um elemento comum aos quatro personagens. Ela é revelada em contraste com a frustração de cada um; Pea, ao perder sua mãe e, consequentemente, a sopa e a paz na cidade, aguarda pelo dia em que tudo possa voltar ao normal; Miggery, desmoralizada por todos, sonha em ser uma princesa; Roscuro, magoado, olha apaixonado 
para luz, escassa no calabouço; e Despereaux, como o mais esperançoso, ignora tudo de negativo a sua volta, focando-se em suas histórias.

Uma das questões que sustentam a moral ingênua na cultura popular é o pensamento sobre como exigir que a moral de uma sociedade justa e igualitária seja a mesma em uma desequilibrada, em que os membros devem lutar entre si para sobreviver? Essa ideia justifica muitas das ações presentes na história, como o efeito bola de neve, iniciado pela princesa Pea.

É importante destacar que a utilização de personagens típicos dos contos de fadas tradicionais, como membros da família real e animais falantes quebram paradigmas relacionados ao seguimento de regras. Na trama, rei e princesa saem do plano da nobreza, tida como algo inatingível, para mostrarem seu lado humano, com medos, anseios e tristezas, e os personagens que deveriam ser antagonistas, devido a suas posições sociais e a forma como são tratados, surgem como protagonistas e merecedores de um final feliz. Nesse sentido, a construção da personalidade de personagens tradicionais em um contexto atual diverge do que foi idealizado pela estética clássica ao se expor mais a fundo suas perspectivas e sentimentos sobre a vida.

Na cena em que Roscuro é ameaçado por Despereaux, antes de a princesa defendê-lo, Roscuro admite ter feito tudo o que fez somente para ter um pouco de beleza em sua vida, alguma luz para si:

[...] E o cheiro da sopa atingiu sua alma como uma grande onda trazendo-lhe a memória da luz, o candelabro, a música, as gargalhadas, tudo, todas as coisas que ele jamais teria como um rato [...] [Tradução minha, p. 262]

O narrador mostra que, mesmo tendo conseguido passe livre para andar pelo castelo, ele foi tentar buscar felicidade em outro lugar, pois um coração despedaçado jamais pertence a lugar algum.

And the smell of soup crashed through his soul like a great wave, bringing with it the memory of light, the chandelier, the music, the laughter, everything, all the things that were not, would never, could never, be available to him as a rat (p.262). 
Há algumas construções do psicológico dos personagens que são mais complexas, como a frustração de Roscuro consigo mesmo e com tudo que aconteceu. A persistência deste tipo de sentimento mesmo depois da obtenção do perdão, que se faz contrário ao esperado, desperta na criança, a partir desse estranhamento, a possibilidade de questionar-se, fomentando em si um pensamento crítico. Esse despertar geralmente ocorre em leitores mais experientes pela necessidade de decodificação textual de conteúdos que atingem os modos como se dão as relações interpessoais.

Voltando à discussão sobre o leitor modelo, considera-se o nível de compreensão dos leitores para que se possa delimitar o modo que será realizada a exposição do valor dos personagens naquela sociedade e, consequentemente, sua função social. Segundo Ely e Zanesco (2013, p.6), "para que essa análise literária seja profícua, precisa-se de muito conhecimento cultural, e não somente uma simples leitura onde se entenda somente o sentido denotativo das palavras, mas que se compreenda a mensagem implícita que está nas entrelinhas do texto".

Na narrativa, Despereaux se vê como o cavaleiro das histórias que lê e inicia sua jornada com o objetivo de salvar a princesa que foi raptada por Miggery e Roscuro. Esse fato desperta no camundongo, que já não tinha medo, coragem e reconhecimento dos seus valores. Ele enaltece seu amor pela princesa tornando qualquer empecilho menos importante. O narrador do livro aparece como se quisesse dizer que todos têm o direito de sonhar:

Leitor, você pode se fazer esta pergunta, na verdade, você deve fazer essa pergunta: não é ridículo um camundongo minúsculo, doente e orelhudo se apaixonar por uma bela princesa humana chamada Pea? A resposta é: sim. Evidente, é ridículo. $O$ amor é ridículo, mas também maravilhoso e poderoso. E o amor de Despereaux pela Princesa Pea com o tempo provará ser tudo isso: poderoso, maravilhoso e ridículo. [Tradução minha, p.32]

Não é mais necessário que os protagonistas tenham atributos mágicos que o auxiliam

Reader, you may ask this question; in fact, you must ask this question: Is it ridiculous for a very small sickly, bigeared mouse to fall in love with a beautiful woman princess named Pea? The answer is... yes. Of course, it is ridiculous. Love is ridiculous. But love is also wonderful and powerful and Despereaux's love for the princess Pea would prove in time, to be all of this things: powerful, wonderful and ridiculous (p.32) 
para conquistar a criança. Logo, longe de uma vida sobrenatural, eles vivem a mesma realidade conturbada experimentada pelo leitor. De acordo com Khéde (1984, p.27),

\begin{abstract}
"a construção da obra depende da visão de mundo do narrador que 'faz' a realidade", isto é, o olhar e o recorte que o narrador lança para a realidade; esta como forma de representação e expressão [...] Com isso, as obras contemporâneas estabelecem um diálogo imediato com o leitor que se reconhece no texto. Sendo assim, o ficcional ganha uma dimensão ideológica porque pressupõe que o leitor reconheça no texto valores que são seus, de sua cultura e de sua classe social.
\end{abstract}

Por se tratar de ambivalências, os sentimentos de frustração x esperança não ocorrem tão facilmente. Nesse meio tempo, é desencadeada uma relação de efeito dominó: a princesa desconta sua raiva da vida em Miggery, que, antes era vítima, agora, com ódio, se torna vilã com sede de vingança. Roscuro, também enraivecido pela forma como foi tratado ao cair na sopa, planeja se livrar da princesa e convence Miggery a trancá-la no calabouço. Despereaux, embora não tenha, de fato, um lado mau, tem duas situações de autocrítica, explanados pelo narrador. A primeira é sobre o perdão de seu pai:

Perdão, leitor, é algo como esperança e amor: poderoso e maravilhoso... e ridículo também. Não é ridículo que, depois de tudo, pensar que um filho poderia perdoar um pai por bater o tambor que o enviou para a morte? Não é ridículo pensar que um camundongo poderia perdoar tamanha perfídia? Mas Despereaux disse estas palavras ao pai: "Eu lhe perdoo". E ele disse aquelas palavras porque sentiu que era a única forma de salvar seu próprio coração de ser partido. Despereaux, leitor, falou tais palavras para salvar a si mesmo [Tradução minha, p.207-208].

A segunda é sobre seu impulso de tentar matar Roscuro:

Despereaux, tremendo, segurou a agulha contra o coração de Roscuro. $O$ camundongo sabia que como cavaleiro seu dever era proteger a Princesa, mas matar faria realmente a escuridão ir embora? [Tradução minha, p. 262].

Forgiveness, reader, is, I think, something every much like hope and love, a powerful, wonderful thing, and a ridiculous thing, too. Isn't it ridiculous after all, to think that a son could forgive his father for beating the drum that send him to this death? Isn't it ridiculous to think that a mouse could ever forgive anyone for such perfidy? But still here are the words Despereaux Tilling spoke to his father: He said " I forgive you, Pa". And he said those words because he sensed that it was the only way to save his own heart, to stop it from breaking in two. Despereaux, reader, spoke those words to save himself (p.207-208).

Despereaux, held the trembling needle against Roscuro's heart. The mouse knew that as a knight, it was his duty to protect the princess. But would killing the rat really make the darkness go away? (p.262) 
Esse efeito de ação e reação entre os personagens reflete a tendência atual de o individualismo ceder espaço ao espírito comunitário. Questões individuais passam a ser problema de todos em uma inversão de valores completamente diferente dos tradicionais. Desenvolve-se, então, um senso comunitário a fim de diminuir desigualdades e injustiças sociais.

Pea, causadora da ira de Roscuro e Miggery, perdoa e obtém o perdão dos dois. Seu pedido de desculpas é feito pensando na resolução de seus problemas:

[...] Eu acho, leitor, que ela estava sentindo a mesma coisa que Despereaux sentiu quando seu pai implorou por perdão. Isso quer dizer que Pea de repente estava consciente de como seu coração era frágil, de como havia escuridão nele lutando contra a luz. Ela não gostava da ratazana, na verdade ela jamais iria gostar dele, mas ela sabia que deveria fazer isto para salvar seu próprio coração [...] [Tradução minha, p. 264].

Os conflitos internos de Despereaux e Pea diante das adversidades mostram maior poder de autocrítica e sensatez. Em uma postura madura, cientes de seus erros, fazem uso da razão para trazer harmonia à situação. Novaes Coelho aponta que os heróis virtuosos e invencíveis já não existem mais e a meta do alcance da perfeição deu lugar à busca pelo aperfeiçoamento, construído progressivamente a cada aprendizado (COELHO, 2000, p.1728).

Como resultado, por não serem nem totalmente bons nem totalmente maus, ainda que tenham agido de má fé, suas ações são colocadas na balança por se tratar de reações às injustiças socioculturais. Com isso, há a possibilidade de arrependimento e, por conseguinte, ocorre a redenção. O narrador coloca o perdão e a união de todos eles como o ideal para um final feliz.

[...] I think, reader, that she was feeling the same thing that Despereaux had felt when he was faced with his father begging him for forgiveness. That is, he was aware suddenly of how fragile her heart was, how much darkness was inside it, fighting, always with the light. She did not like the rat. She would never like the rat, but she knew what she must to do to save her own heart (p.264) 
Mas a pergunta de que eu sei você quer saber a resposta é eles viveram felizes para sempre? Sim...e não. [...]Antes de ir embora, leitor, imagine um rei amável e uma bela princesa, uma serviçal surda com uma coroa e uma ratazana com uma colher na cabeça, todos juntos a uma mesa no salão real e, no meio dela, uma enorme panela de sopa. Sentado em um lugar de honra, ao lado da princesa, há um pequeno camundongo de orelhas enormes. E espiando atrás de uma cortina de veludo empoeirada, olhando surpresos para a cena, estão quatro outros camundongos [Tradução minha, p. 267-269].

Os contos de fadas de antigamente eram lineares e curtos. Os traços de violência e agressividade contra o personagem principal não eram explicados, mas expunham o contraste entre a infelicidade de suas vidas e o "felizes para sempre" no final. No contemporâneo, há um espessamento do discurso literário, passando a autorreferenciar-se, como forma de ensinar enquanto narra. Portanto, a literatura e a educação passam a complementar-se, sempre tendo como apoio os efeitos da contemporaneidade:

O que percebemos é que a mimese volta à tona na contemporaneidade, e isto dá certo "poder" para a literatura abordar e discutir temas que, na perspectiva do leitor, possam sofisticar ou esclarecer seus valores culturais e mostrar novas abordagens sociais e políticas de sua realidade. Não que a literatura seja um manifesto ou panfleto político, longe disso; seu poder artístico e sua função formadora são tão relevantes que ela tem a capacidade, através de sua linguagem e de sua essência artística, de ser absorvida pelo sistema e também subverter essa estrutura. (THEODORO; PINTO, 2012, p.5).

But before you leave, reader, imagine this: Imagine an adoring king and a glowing princess, a serving girl with a crown on her head and a rat with a spool on his, all gathered around a table in a banquet hall. In the middle of the table, there is a great kettle of soup. Sitting in the place of honor, right next to the princess, is a very small mouse with big ears. And peeking out from behind a dusty velvet curtain, looking in amazement of the scene before them, are four other mice (p.267-269). 


\section{ADAPTAÇÃO CINEMATOGRÁFICA}

\subsection{Obra fílmica x literária}

A forte influência dos clássicos da literatura sobre diversas áreas do conhecimento contribuiu em muito para que as histórias mais recentes, tidas como originais, tivessem traços de sua composição. Suas narrativas foram recontadas e parodiadas, décadas após décadas, pelos mais diversos meios de comunicação.

O cinema, sob a ótica da adaptação de obras literárias, expõe essa influência ao manifestar-se como intertexto, a depender dos objetivos da adaptação. Sua releitura passa por um processo de transformação de signos linguísticos em signos audiovisuais, próprios de seu meio e, uma vez que trabalha com sistema de códigos diferentes, irá apresentá-los à sua maneira.

Assim como o leitor na literatura, pode-se considerar que o espectador fará uma leitura da obra audiovisual, na medida em que se lê a imagem e o discurso. Essa linguagem é formada por um conjunto de técnicas que envolvem criação de luz, movimento, cores, pensadas estrategicamente para atrair o espectador.

Uma das principais características que distinguem a linguagem verbal da audiovisual é a noção de dupla articulação. A primeira articulação é a dos morfemas, menor unidade mínima de significação que não possui existência no mundo real, possuindo apenas significação gramatical. A segunda é o fonema, responsável por diferenciar uma palavra da outra. A primeira articulação pode operar no nível do significante e do significado ao passo que a segunda, ao trabalhar no nível da forma vocal, opera no significante. Para Cristian Metz, O cinema não é composto nem pela primeira nem pela segunda articulação, pois seu significante está muito próximo ao significado, fazendo com que sua interpretação seja uma só (METZ, 1972, p.79-81). Ele acredita que por possuir signos distintos e não ter a capacidade de ser reduzido a unidades mínimas, o cinema não pode ser visto como língua, mas, servindo de ferramenta de comunicação, ele constitui-se como linguagem. 
A imagem irá obter sentido somente dentro do contexto, a depender do modo com que será situado em um discurso ou irá se relacionar com outras partes presentes nele. Ao contrário do livro, que guia o leitor a assimilar a história a sua maneira, a obra fílmica não é plurissignificativa nem plurissituacional. A literatura mexe com recursos ligados à imaginação. Parte da criatividade do autor na criação de personagens, cenários e tramas para ser, posteriormente, reimaginada pelo leitor, que irá, em seu próprio universo, acompanhar a história. O cinema, em contrapartida, está ligado à interpretação ao envolver o espectador em uma visão preestabelecida por um diretor e um roteirista.

Marcel Martin (2003) explica que essa particularidade ocorre devido ao fato de sua mensagem ser reproduzida a partir da fotografia da realidade. É por meio da interação dos seres com os objetos cenográficos que impressões e sensações são ativadas na imaginação. Com isso, "parece que qualquer representação (o significante) coincide de forma exata e unívoca com a informação conceitual que veicula (o significado)" (MARTIN, 2003, p.24).

Seguindo essa linha de raciocínio, o cinema só reproduz elementos exteriormente, limitando-se às aparências e à psicologia do comportamento. Segundo Bazin (1991):

\footnotetext{
A maioria das imagens do cinema está alinhada à psicologia do teatro ou do romance clássico, presumindo com o senso comum, uma relação de causalidade necessária e sem ambiguidade entre os sentimentos e suas manifestações; postulam que tudo está na consciência e que a consciência pode ser conhecida (BAZIN, p.1991, p.90).
}

A representação é mediatizada pelo tratamento fílmico, trabalhando para reestruturar imagens de objetos de acordo com a proposta narrativa, o que significa que sempre há algo a se dizer. Quanto mais se entende seu significado contextual, mais ele perde seu valor real. Essa ambiguidade criada a partir do real x imaginário é uma das etapas que determinará a relação da obra com o espectador, variando de acordo com o grau de percepção intuitiva ou intelectual dos signos implícitos nessa linguagem. (MARTIN, 2003, p.24-25)

O cinema, tende a lidar com imagens concretas, desafia o espectador, no caso leitor, ao trazer percepções diferentes daquelas vivenciadas por ele durante a leitura. Esse fato ocorre involuntariamente e será diferente para cada leitor. Por este motivo, adaptações baseadas em histórias pouco conhecidas recebem menos críticas do que aquelas inspiradas em obras canônicas. Então, pode-se dizer que uma adaptação nunca agradará a todos. 
Martin Esslin (1990, apud DINIZ, 1998, p.315) apresenta uma diferença básica entre os signos presentes na indústria cinematográfica. Para ele, há os denotativos, que se dividem em dois grandes grupos: os comuns a toda forma de expressão, em que o ator os interpreta ao fazer uso do texto pronto, recursos visuais e orais, e aqueles pertencentes exclusivamente ao cinema, que são os derivados do trabalho da câmera, ligação entre planos e edição, estes, utilizados para caracterização de personagens e cenário. No nível conotativo, há a transmissão de mensagens morais, filosóficas, políticas, vinculadas a uma combinação de signos que dependerão do contexto que foram inseridos (ESSLIN, 1990, apud DINIZ, 1998, p.315).

Ao analisar-se uma adaptação, é crucial que os aspectos ideológicos e contextuais sejam incluídos bem como, por meio de uma perspectiva intertextual, seja realizada uma avaliação do texto fílmico como resultado de inúmeras obras e sistemas diferentes, em uma relação intersemiótica (DINIZ, 1999).

Nesse sentido, a fidelidade na adaptação deixa de ser o critério maior de juízo crítico, para ser avaliada em sua forma, em seu próprio direito como filme. Acréscimos e supressões nas adaptações podem ser facilmente reconhecidos pelos críticos, mas dificilmente haverá um consenso quanto ao sentimento ao fazer modificações e preservações, pois elas deverão ser analisadas juntamente às outras dimensões que o filme apresenta, como elementos de estilo específicos do meio (XAVIER, 2003, p.62-67).

O cinema, antes influenciado pela literatura, agora se torna um disseminador de artes consagradas, sendo uma arte consolidada. Transfere-se então a preocupação com a fidelidade para a noção de que as adaptações podem promover leituras e releituras de um mesmo material, em um processo de interpretação e criação de algo novo, simultaneamente (HUTCHEON, 2001, p.45).

\subsection{Técnicas cinematográficas na construção da narrativa e dos pontos de vista}

$\mathrm{Na}$ arte da narração, há a diferença entre mostrar e contar. Existem diversas maneiras de se narrar um acontecimento. De modo geral, a descrição de uma sucessão de fatos sugere 
vários sentidos, e, por conseguinte, vários modos de narrar. Com isso, viabiliza-se uma infinidade de possibilidades para se explorar sua estrutura textual, propiciando o leitor a estar sempre aberto a um horizonte de expectativas e nunca perder o interesse pela leitura.

Coloca-se o narrador em diversas posições, pensadas especificamente para descrever uma cena da maneira que melhor se adequar ao tipo textual e à transmissão do conteúdo. Por isso, muitas vezes, ela é vista como instrumento revelador dos propósitos do autor, expondo, por meio de sua técnica, valores e convicções.

Como já foi mencionado, um material produzido para grandes massas revelará a intencionalidade do autor em consonância com o público e as ideologias pelas quais ele faz parte. A obra não só deve ir ao encontro do que a cultura-alvo exige, como também, no caso de obras literárias e fílmicas, agir de modo a atingir o indivíduo em seu íntimo, proporcionando a tão buscada identificação nos enredos. No cinema, essa idealização é alcançada por meio da construção do ponto de vista em conjunto com a ancoragem.

O termo ponto de vista constitui-se de uma série de fatores a depender do contexto textual no qual serão utilizados. Independente da linguagem, a narrativa é decorrente de uma estrutura fechada com elementos específicos necessários para sua concretização de personagem, tempo, espaço, narrador e acontecimentos.

Há, pelo menos, três sentidos em sua atuação: o literal/percepção, pelos olhos de alguém; o figurativo/conceitual, pela visão de mundo de alguém; e o transferido/interessado, que evidencia o interesse de alguém. Esses três aspectos da percepção mostram que um elemento pode ser percebido literalmente por um personagem, representado de acordo com sua compreensão ou mesmo a partir do grau de interesse invocado por ele (CHATMAN, 1978, p. 153).

A literatura por si só passou por constantes renovações no que se refere a formas de narração e pontos de vista. Esses modos de se contar uma história, adaptados ao meio cinematográfico, exploram a fundo as técnicas pensadas para uma reprodução o mais próximo possível da vida. A câmera, como instrumento capaz de simular o olhar humano, move-se em várias direções, focando e desfocando objetos no enquadramento em conformidade com os propósitos do observador. Assim, há uma transgressão de espaço e tempo, permitindo o 
espectador decompor e recompor a realidade, deslocando-se abruptamente uma sequência à outra, sem a presença, necessariamente, de um narrador. Essa justaposição de ângulos manifesta a visão do artista sobre o fenômeno (EISENSTEIN, 1969, p. 174-176).

Não somente tido como fator estético, o posicionamento da câmera em conjunto com a montagem cenográfica resultam em pontos de vista que ultrapassam a mera representação da percepção visual para refletir crenças e aspirações. A precisa noção do contexto sociocultural do público-alvo durante a elaboração de técnicas é condição fundamental para que haja o reconhecimento do eu.

De acordo com Marcel Martin (2005, p.27-28), a imagem fílmica restitui exata e totalmente o que é oferecido à câmera. Portanto, ela é realista, objetiva. A noção de movimento somada à sonoplastia é importante para se reconstruir seres e coisas que sentimos na vida real. Marcel discute a imagem fílmica como instrumento que suscita sentimento de realidade, por vezes, tão intenso ao ponto de provocar a crença na existência do que está na tela.

Essa possibilidade de densificação do real, oferecida pela visão artística do realizador, torna-se afetiva à percepção do espectador, na medida em que se constroem as tramas no plano da significação. Contudo, por mais que sejam produzidos fielmente acontecimentos sob as lentes, a imagem não fornecerá qualquer indicação sobre seu sentido. Com isso, pode-se dizer que a imagem mostra e não demonstra (idem p.31-32).

A imagem por si só carrega polivalência significativa. Ela pode implicar diferentes inferências por parte do espectador quanto ao seu objetivo, só não podendo fornecer informações sobre seu tempo de ação. Eis o motivo pelo qual o comentário se faz tão importante nesse meio (idem p.31-33).

O ponto de vista na obra fílmica é o que se percebe a partir do ponto de foco, que é tudo que atrai o foco do narrador ou de um personagem. Sua apreensão se dá de maneira subjetiva e, para que seja captada, é aliada à construção dos personagens e ao auxílio do narrador, que interpretará e selecionar certos pontos de foco para "facilitar a composição e a recepção" (CAMPOS, 2007 p.40-47). 
Essa condição de subjetividade é denominada elipse narrativa e permite a omissão de informações que possam quebrar a linearidade da representação, e em alguns casos, servem para manter o decoro. Nesse sentido, ela é inseparável do conteúdo explícito e é captada pelo público por meio de sua intertextualidade com outros textos pertencentes ao mesmo campo histórico e/ou cultural.

Friedman (2002, p.172-175) identifica que, no que concerne aos modos de transmissão, em qualquer sistema existe o sumário narrativo, que se apresenta como um relato generalizado de uma série de eventos acerca de uma variedade de locais em uma extensão de tempo, e a cena imediata, que emerge tão logo diálogo, personagens, ações e detalhes surgem. Ele aponta que, embora personagens hajam por si mesmos, há uma tendência predominante de o autor descrevê-los e explicá-los ele mesmo.

Na literatura, o ponto de vista, para Bourneuf e Ouellet, (1976, p.106), acontece de modo mais complexo do que na vida real, pois há um personagem, um narrador e a presença implícita do autor, que expressam outros pontos de vista simultaneamente. No cinema, utilizam-se vários recursos cinematográficos como planos e fundo, travellings, montagem, sonoplastia, enquadramento, entre outros, com a finalidade de se criar um discurso inteligível e com boa aceitação por grande parte do público.

Nesse sentido, a variedade de tecnologias midiáticas e sua infinidade de combinações surgem como oportunidade de constante reinvenção da narrativa. Em adaptações cinematográficas, logo surge à mente quais os percursos e estratégias utilizadas para sua realização. Essas produções, tidas como adaptações, são comumente criticadas por especialistas que, muitas vezes, esquecem-se que a efetivação de sua reescritura depende do sistema semiótico ao qual será criado.

Tendo-se conhecimento da importância do papel do narrador e da delimitação dos pontos de vista em ambos os sistemas, serão expostos alguns fatores que afetam as decisões do autor/diretor na construção narrativa. Friedman (2002, p.172) define algumas questões acerca do que pode servir como delimitação para uma transmissão narrativa bem-sucedida. São elas:

Quem fala ao leitor? O narrador está em qual pessoa do discurso? 
De que ângulo ele conta a história? De que posição em relação ao enredo ele o conta? De cima, alternado, do centro, frontalmente?

Quais canais de transmissão ele utiliza para transmitir a mensagem ao leitor? Pensamentos, palavras, percepções, sentimentos do narrador ou do personagem?

Com essas possibilidades, a partir de quallquais delas as informações sobre estados mentais, cenário, situação e personagem surgem?

A partir dessas concepções, ele identifica alguns tipos de narração encontrados nas histórias:

Existem vários tipos de onisciência. No narrador onisciente neutro, por exemplo, o autor fala de modo impessoal, na terceira pessoa. Na onisciência seletiva múltipla, não existe narrador e a compreensão do enredo ocorre indiretamente pela direção da cena na exteriorização de pensamentos ou na própria fala de qualquer um que esteja presente. Assim, tudo que é pensado ou sentido é transmitido ou público de maneira consecutiva. $\mathrm{Na}$ onisciência normal, o narrador sumariza as sequências depois que elas acontecem (idem p.177).

Quando a onisciência é seletiva, a história limita-se à mente de um só personagem e seu ângulo de visão encontra-se no centro fixo. Nesse caso, há certa desvantagem pelo fato de a variedade de fontes ser limitada aos próprios pensamentos. Quando essa seleção é voltada para o protagonista, sua história se faz em primeira pessoa. Ele, assim como o narrador testemunha, pode resumir o ocorrido à curta ou longa distância. A diferença é que o último é alguém parcialmente envolvido na trama, que fala com o público na primeira pessoa (idem p. 180). Como consequência, como não se terá acesso aos estados mentais alheios, ter-se-á a opinião da testemunha (idem p.176).

Essa categorização de onisciência deve ser avaliada junto com elementos que compõem as cenas primordiais para sua compreensão. Para isso, Shohat e Stam (2006, p.303) trazem os seguintes questionamentos:

Estes são personagens ativos ou decorativos? 
Com que frequência e quanto tempo eles aparecem em cena?

São vistos em close-up ou à distância?

O espectador é levado à identificação com o olhar de qual tipo de personagem?

De que forma a linguagem corporal, expressão facial e postura sugerem hierarquias sociais, arrogância, servidão, ressentimento, orgulho?

Como o posicionamento dos personagens indica distância social ou de status?

Quais olhares são correspondidos e quais são ignorados?

Há segregação estética através da qual um grupo é idealizado ou demonizado? A temporalidade e a subjetivação transmitem hierarquias sutis?

Que homologias informam as representações artísticas e étnicas/políticas?

\subsection{Cinema de animação}

A ascensão dos recursos cinematográficos por meio do aprimoramento da computação gráfica contribuiu em muito para o uso de novas técnicas no cinema de animação. Entre várias outras mudanças, como maior detalhamento de expressões faciais, novos posicionamentos de câmera e melhor definição, comparadas aos desenhos animados clássicos, os filmes de animação inovam também pela possibilidade de proporcionar três dimensões às cenas.

A trajetória do desenho de animação foi, pouco a pouco, sendo mundialmente delimitada. Observa-se a tendência a fugir ao padrão de histórias voltadas a um público infantil homogêneo para uma nova perspectiva que atinge crianças de diversas faixas etárias e adultos.

Pautando-se nas transformações da sociedade, o cinema evolui significativamente de modo a tornar-se uma arte sofisticada ao abordar cada vez mais questões éticas e morais. Com isso, a construção da representação imagética de um filme requer precisão. Para sua produção, 
há um conjunto de signos próprios de seu sistema que influenciam a percepção humana como trilha sonora, figurino, ambientação, cenários e ideologias a serem transmitidas. Ideologias estas que por meio de caracterizações socioartísticas e culturais atuam não só sobre o desenvolvimento infantil, como também fomentam a formação de sua identidade e inclusão na sociedade (SILVA, GOMES, 2009, p.37-38). Sobre o papel dos meios de comunicação na vida do indivíduo:

\begin{abstract}
A 'verdade' presente nos saberes estabelecidos pela mídia, tecida nas redes simbólicas das quais emergem discursos dos mais variados campos, produz modos de ser que constituem subjetividades. Na medida em que é também construtora e propagadora de imaginários, a mídia serve de referencial para a produção de identidades (GOMES, 2001, s/p).
\end{abstract}

A sociedade é condicionada pelos meios produtores de cultura. A partir deles moldamo-nos a parâmetros sociais e políticos, importantes para a formação do homem. Tudo que se relaciona à comunicação em massa pertence, a certo grau, à indústria cultural, responsável por homogeneizar a visão de mundo de diversas populações. Ela é parte do sistema capitalista e está presente no cotidiano, condicionando comportamentos por meio de influências de um imaginário estereotipado (SILVA, 2007, p.41).

Mas não é somente por seu caráter intercultural que as animações têm conquistado diversos públicos. Um aspecto importante desse gênero é sua vertente lúdica/cômica que, diferentemente dos filmes tradicionais, permite que o irreal e o inesperado aconteçam. Transgressões da lei da física, como personagens mudando de forma, cenários aumentando e diminuindo, objetos se tele transportando somados a um toque de humor inteligente promovem a ampliação de públicos para sua circulação.

É justamente por esses eventos ilógicos que se torna possível a aceitação por parte do público de personagens fora do padrão. Há a possibilidade de se criar traços de personalidade extravagantes, atitudes incoerentes. Tudo isso é possível pelo trabalho de diversos recursos cinematográficos que ajudam na edificação do carisma de personagens inusitados.

Entre outras técnicas, o princípio da montagem continua sendo o mesmo. Mecanismo de sequenciamento e significação, no cinema animado precisa ser definido no início, pois o movimento a cada frame deve ter ligação com o próximo, mantendo a continuidade. Pode-se dizer que a animação é definida na pré-produção, que é quando se definem escolhas 
estilísticas, layout, personalidade dos personagens e o curso de suas ações. Os imprevistos são evitados devido ao alto custo para a produção e o tempo despendido (CRUZ, 2006, p.52).

É importante salientar o processo lento e trabalhoso da elaboração de uma animação. São exigidas várias etapas para que a animação seja finalizada. A primeira delas é o argumento, que é a ideia ou o tema; a segunda é o roteiro que, baseado no argumento, desenvolve todos os detalhes como diálogos, efeitos, ações e timing; e, por fim, o storyboard, que é a demonstração gráfica do roteiro (KINDEL, 2003, p.57).

A velocidade com que ocorre a narrativa pode ser considerada uma das marcas fundamentais da pós-modernidade. A subjetividade das histórias é construída em conformidade com os padrões mais atuais, tais como imersão no mundo tecnológico, efemeridade das relações e celeridade de informação. Assim, surgem imagens infantis baseadas na cyber-cultura (DORNELLES, 2005).

De acordo com Halas e Manvell (1979), isso significa maior esforço por parte do espectador:

A animação tende a abreviar a ação: narra sua estória mediante formas e configurações simplificadas que transmitem aos olhos e à mente um rápido fluir de acontecimentos. A compreensão é uma das virtudes da animação, e o esforço que se exige da plateia num dado espaço de tempo requer um grau de concentração maior do que normalmente necessário para o seguimento de um filme comum (HALAS; MANVELL, 1979, p.148, apud KINDEL 2003).

Além das etapas já mencionadas, costuma-se dividir a criação do filme em três partes: pré-produção, produção e pós-produção. Cada estágio depende da execução de tarefas distintas, cujos resultados devem ser aprovados em última instância pelo diretor. Uma vez que os dispositivos técnicos da animação se diferem daqueles tradicionais dos desenhos, ela requer uma série de procedimentos específicos, sobretudo na parte referente à produção (CRUZ, 2006, p.77).

A pré-produção envolve tarefas não visuais como roteirização, convocação do elenco, estipulação de prazos, gravação dos diálogos, etc. Tendo o argumento pré-definido, pode-se estabelecer o enredo e a importância de cada personagem na trama. A partir do roteiro, obtémse o ponto de vista pelo qual será contada a história bem como os pontos de maior conflito e suas soluções. Inicia-se então o trabalho relacionado ao conceito artístico pela realização de 
desenhos para inspirar a equipe. Esta tarefa antecede o storyboard e permite que a equipe explore opções de design mais adequadas ao filme. Daí por diante, é definida a paleta de cores de cada cena de acordo com a atmosfera que se deseja simular (KERLOW, 2004; THOMAS, JOHNSON, 1981; CRUZ, 2006).

$\mathrm{Na}$ fase da produção, o animador dá vida aos seres inanimados. Com personalidades, cenários e características delimitadas, segue-se para modelagem 3D, que pode ser realizada por meio de uma série de técnicas isoladas ou integradas, dependendo do nível de detalhamento que se quer alcançar. Os animadores são responsáveis pela comunicação desses personagens na tela, atentando-se à forma como ele criará movimentos, expressividades, e tensão gerada, seja através do diálogo, gestos ou olhares. Com a cena já animada, ela ganha luz e efeitos visuais, processo que demanda recursos mais complexos, como o uso de uma câmera simulada, operada pelo computador, estabelecendo planos, ângulos e movimentos de profundidade do campo. Na pós-produção, as imagens podem ser mixadas com outras imagens do computador, distorcidas, retocadas e ajustadas antes de finalmente serem gravadas e destinadas ao público (KERLOW, 2004; CRUZ, 2006).

\subsection{Análise da adaptação}

Os contos de fadas tradicionais apresentam-se como histórias que remetem não à vida real, mas sim a situações hipotéticas que, de acordo com estudos, atingem o subconsciente da criança. Esse tipo de narrativa constrói-se de modo a necessitar a presença de um elemento ou ser fantástico que ajudará o protagonista em sua jornada. Ao longo do tempo, com a atualização do tipo de leitor, houve a necessidade de se retratar os problemas da época sob uma ótica mais realista. O maravilhoso deu espaço para personagens reais, responsáveis por seu próprio destino.

As temáticas atuais ultrapassam as questões existenciais e passam a lidar com problemas cotidianos, como preconceito, racismo, bullying, desigualdade social, etc. Há uma subversão das narrativas infantojuvenis visando-se o politicamente correto. Nesse sentido, a 
releitura contemporânea abrange diversos fatores, incluindo inversões sociais, em que o vilão consegue o carisma do público.

Dito isso, a análise da adaptação cinematográfica da obra para a animação The Tale of Despereaux será realizada em consonância com o conceito de tradução como reescritura, de André Lefevère, levando-se em conta aspectos ideológicos relacionados às circunstâncias da tradução como adaptação de uma obra calcada no conto de fadas tradicional, mas com público contemporâneo. A pesquisa será feita a partir dos aspectos de intertextualidade comentados no capítulo anterior, facilitando uma categorização de elementos que formam a personalidade dos personagens, em que a ordem se dará de acordo com a progressão da identidade conforme a narrativa literária.

Aqui, será exposta a perspectiva de cada um diante das situações por meio de seus pontos de vista/pontos de foco somados ao do narrador. Para isso, foram consideradas as estratégias de posicionamento da câmera e seus pontos de vista e a expressão e postura corporal dos personagens como tradução dos impactos morais nos protagonistas.

No livro, o narrador onisciente fala em terceira pessoa ao introduzir e sumarizar cenas e, quando pretende enfatizar uma lição de moral, chama o leitor em terceira pessoa, pelo vocativo, para acentuar a importância da mensagem transmitida, como forma de conscientização. $\mathrm{Na}$ animação, apesar de as cenas por si só descreverem a narrativa, o narrador também tem esse papel intermediador.

É importante ressaltar que a narrativa expõe o modo de vida de três sociedades: a dos humanos, representada pela devoção do povo ao rei e amor à sopa, distribuída para o reino em um festival; a dos camundongos, em que o conselho dita regras impostas à comunidade sobre como sobreviver, tendo em vista sua fragilidade; e a das ratazanas que, por viverem em um local entre o calabouço e o esgoto, há pouco acesso à comida. Em sua sociedade Botticelli é o líder que controla a quantidade de alimento, no caso, qualquer coisa, e intimida os membros a serem maus. 


\subsubsection{Personagem Despereaux}

Despereaux é um personagem que possui singularidades. Sua aparência física faz com que, desde seu nascimento, haja certo tratamento diferenciado. Ter nascido com os olhos abertos e ter orelhas enormes foram motivos para seus familiares acreditarem que ele não fosse sobreviver. A narradora (com voz de Sigourney Weaver) destaca esses atributos e os descreve como sentidos apurados:
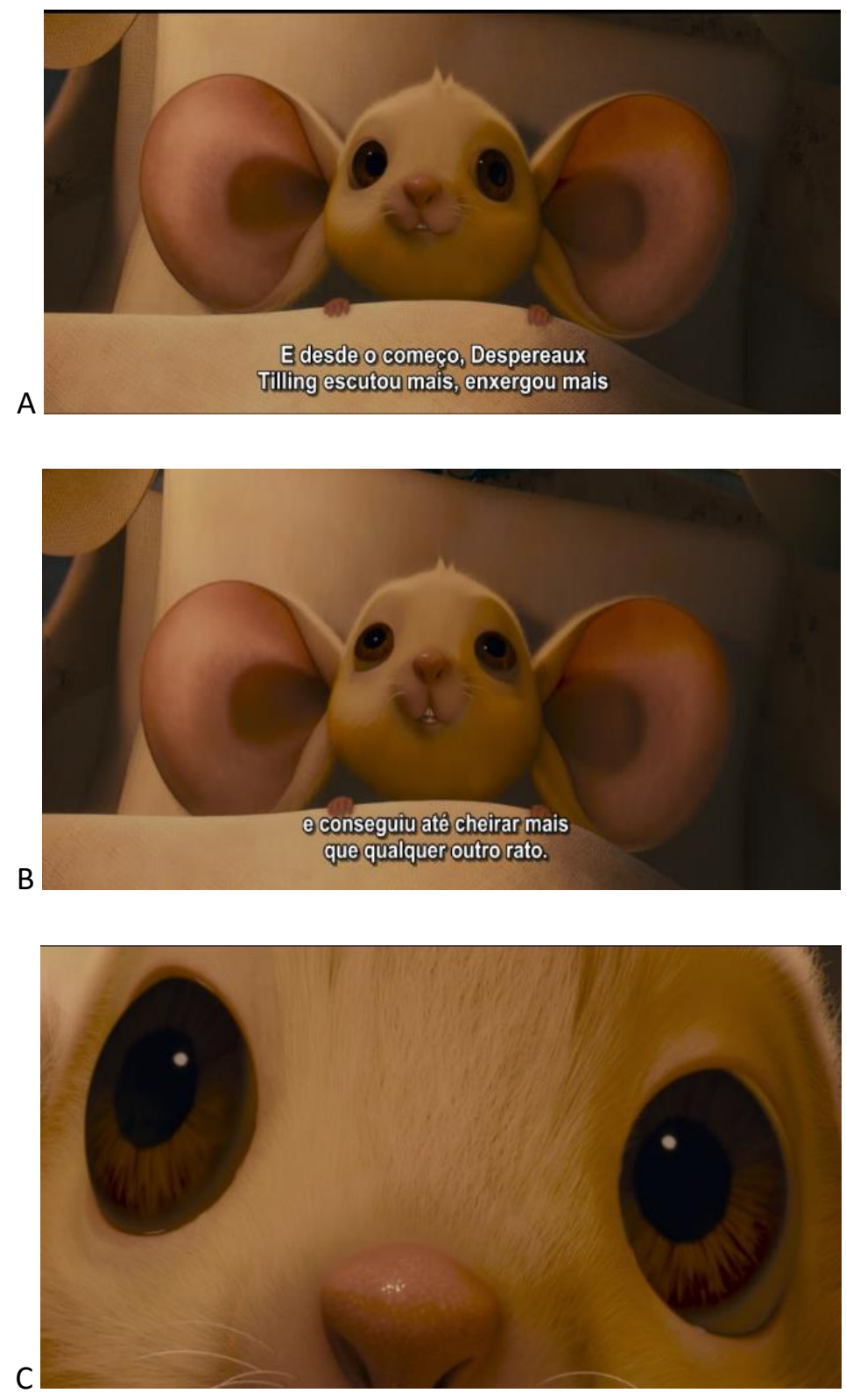

Figura 1 - Características diferenciadas de Despereaux ao nascer. 
Na figura 1, tem-se o destaque de Despereaux ainda bebê olhando atentamente tudo à sua volta. Em $1 C$, por meio do Plano Detalhe - PD, evidencia-se seu olhar fixo e atento às reações dos familiares, que estranham sua postura, sem medo, ao contrário dos demais. Assim, a história do camundongo se inicia deixando algo no ar sobre sua personalidade distinta, ainda não desvendada pelo espectador.

O plano detalhe tem como função dar ênfase ao ponto escolhido pelo autor da imagem. Nesse tipo de composição a imagem ocupa completamente a área, é como o registro de um olhar mais atento, em que as emoções, texturas e formas tornam-se mais expressas e intensas (MEDEIROS, FONSECA, SOUSA, SILVA, LACERDA, 2014, p.6)

Sua fragilidade é representada por rápidas quedas, ignoradas por ele, que se levanta alegre, pois sua ansiedade por aventura e capacidade de ver beleza em tudo supera o meio em que vive, sentimento exposto na figura 2B. De acordo com Martin, o plano contraplongée, em geral, dá a impressão de superioridade, de exaltação e de triunfo, tendendo a magnificar aquele que está sob seu foco (MARTIN, 2013, p.51).

A narradora aparece para deixar claro ao espectador sua força interior:

Despereaux não tinha ideia de que era pequeno. Não era pequeno só para os humanos, era pequeno até para um camundongo. Mas para falar a verdade, ele nunca notou. Na verdade, em seu pensamento, Despereaux era um gigante.
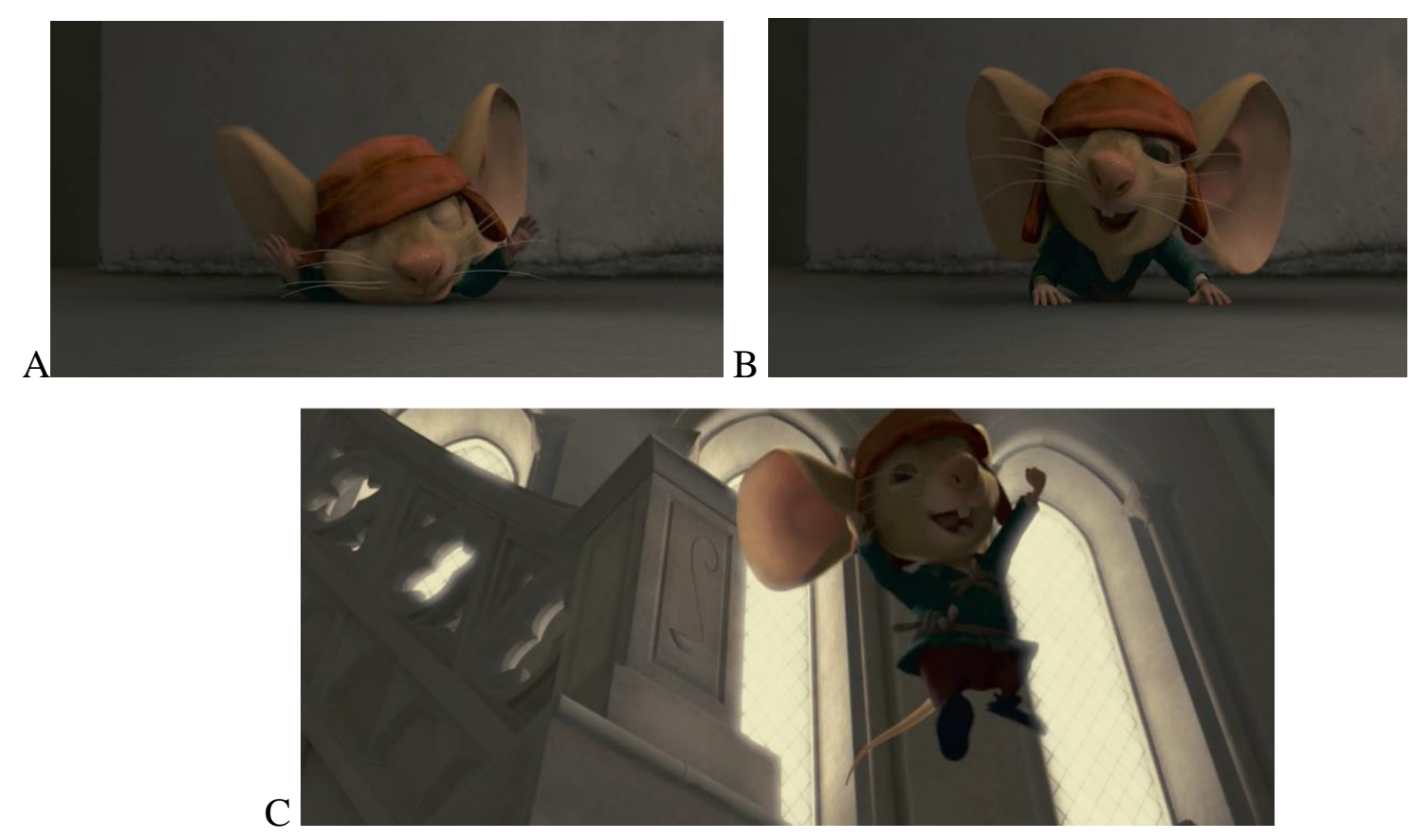

Figura 2 - Autoimagem de Despereaux. 
Mais tarde, ao começar a vida escolar, suas atitudes demonstram uma reação diversa dos outros. Em sua comunidade, os membros dessa sociedade são ensinados a temer qualquer coisa que possa feri-los. Também são orientados a comer as folhas dos livros sem aterem-se a seu conteúdo e a jamais conversarem com humanos. Nenhuma dessas regras são justificadas, sendo apenas aceitas e obedecidas.
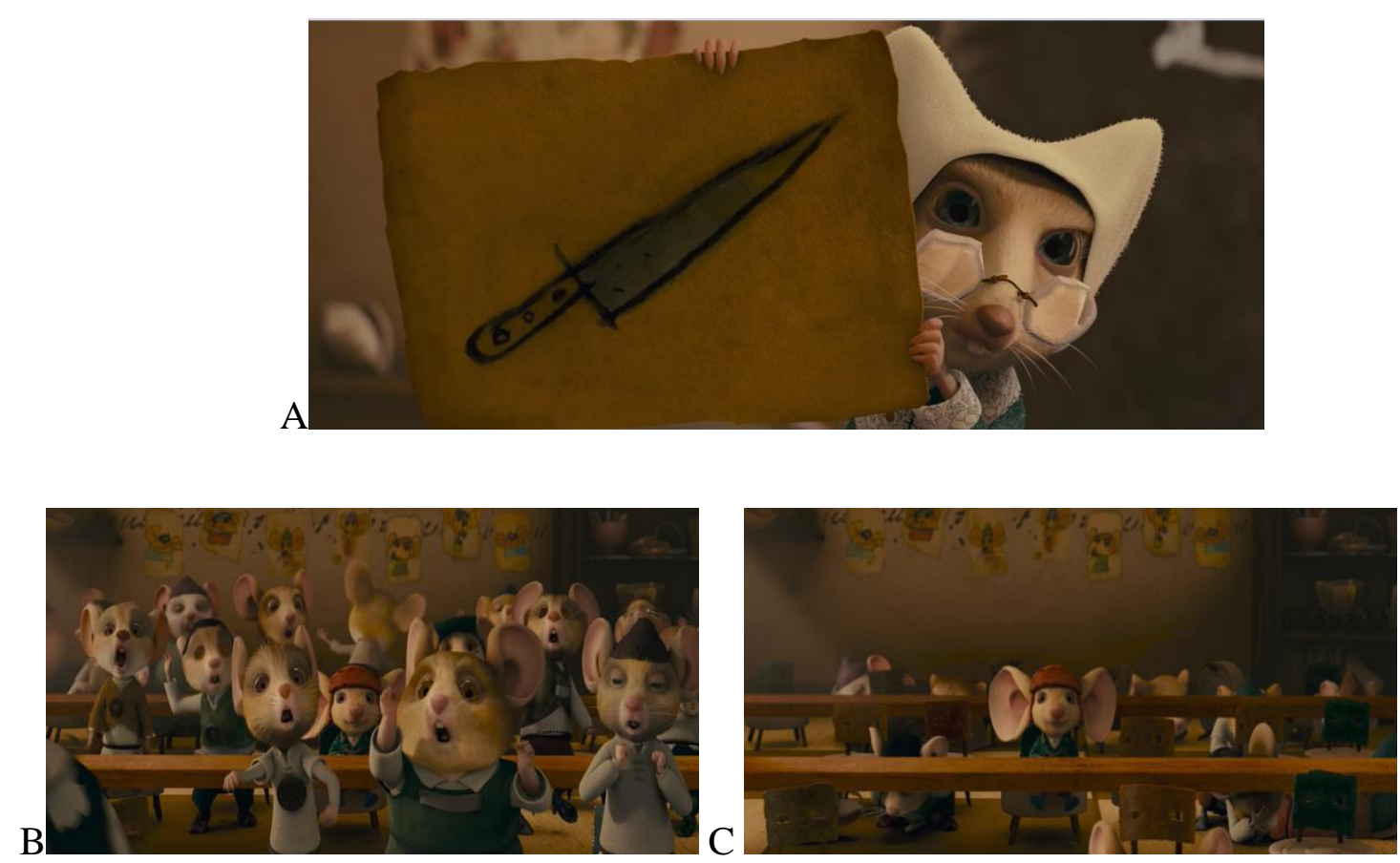

Figura 3 - Reação dos colegas de Despereaux na escola.

A figura 3B, em Plano Conjunto, mostra a diferença da reação dos seus colegas de classe reagindo em pânico ao verem o desenho de uma faca de cozinha nas mãos da professora para a de Despereaux, que se mantém calmo e admirado com a semelhança do objeto com uma espada. No Plano Geral Aberto, na figura 3C, o camundongo não consegue entender por que deve se proteger, o que chama a atenção da professora para uma conduta inadequada. Situações como esta fazem com que Despereaux tenha seu círculo de amizades reduzido. O personagem aparece constantemente sozinho sonhando com aventuras.

A provável identificação por parte do expectador devido à construção de ambivalências nas personalidades é acentuada pelas características humanas nas expressões faciais e corporais. Esse efeito catártico ocasiona, consequentemente, a atenuação de algumas 
atitudes dos personagens secundários no tratamento para com ele. Ainda que seja tratado com certa reserva pelos colegas, eles se preocupam com ele e o acompanham até locais que jamais iriam por conta própria.
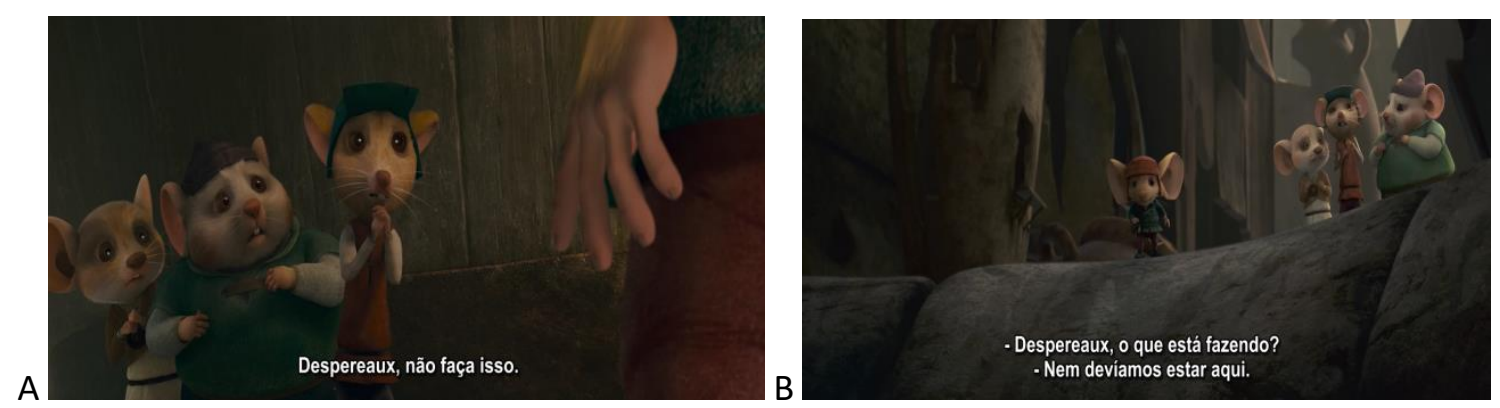

Figura 4 - Preocupação dos colegas.

Na figura 4B, novamente usa-se o Plano Conjunto para contrastar os comportamentos antagônicos. Os três colegas são posicionados ao fundo, agrupados e com expressão corporal representando tensão, enquanto Despereaux aparece sozinho, mais perto da câmera.

Diante de sua insistência em não seguir as normas, os membros mais influentes da comunidade posicionam-se de forma a intimidar seus pais a tomarem uma providência. Temse na figura 5 um dos professores em reunião com os pais advertindo sobre seu histórico. Como não aprende na escola, ele os orienta a colocar o filho para aprender com o irmão mais velho. A autoridade é sempre representada pelos personagens influentes em contraplongèe, demostrando sua superioridade em relação aos membros da comunidade, que se sentem pequenos e sem contra-argumentos diante de tais imposições.

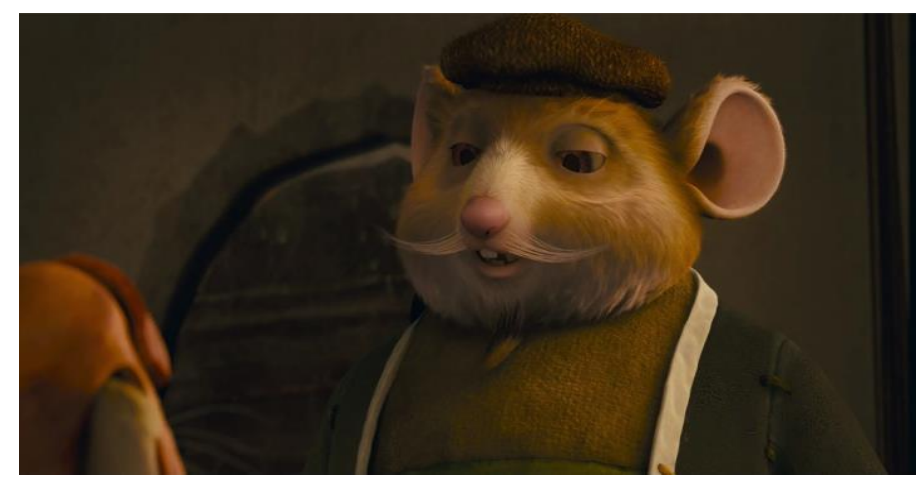

Figura 5 - Professor. 
Vendo que Despereaux não está tentando seguird seus passos, seu irmão, Furlough, o repreende no quarto e, quando seu pai escuta a conversa, se vê obrigado a contar o que houve. O pai, temente às leis, aparece como um covarde e seu medo se sobrepõe ao papel de pai. A figura abaixo enfatiza sua expressão de espanto ao perceber que se não denunciar seu filho ao conselho, ele mesmo ficará mal visto. Enquanto está preocupado com o que deve fazer, a cena ocorre em Plano Médio (cintura para cima) e quando percebe que poderá ser envolvido, passa-se para o Plano Próximo, em que sua expressão é congelada na cena. Essa transição de planos obtém destaque, pois é partir desta imagem que o espectador entenderá que Lester denunciou o filho ao conselho, já que ocorre uma elipse desta cena pela mudança de enquadramento para a de Despereaux sendo intimado.
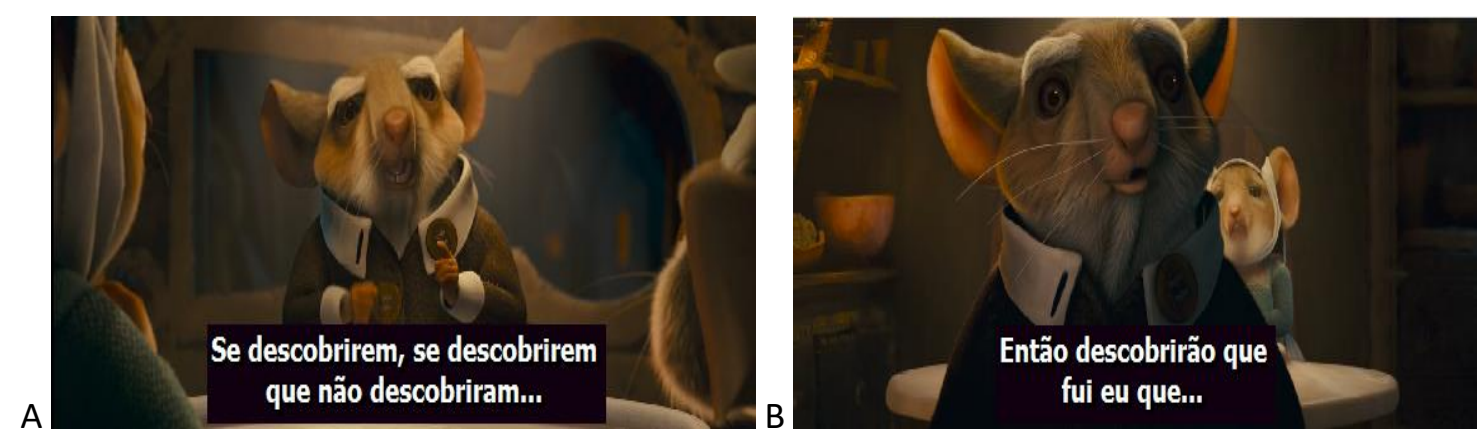

Figura 6 - Covardia de Lester.

No livro, o narrador mostra claramente que seus familiares tiveram péssimos atos. Seu pai, além de denunciá-lo é membro do conselho responsável pela determinação do grau de acusação e sua mãe desiste facilmente do filho e diz adeus. No filme, essas atitudes são mais humanizadas. Na animação, a mãe chora muito pela perda do filho e seu adeus é somente gesticulado e a pior atitude do pai, aqui, está em não permitir que a esposa se despeça do filho. 

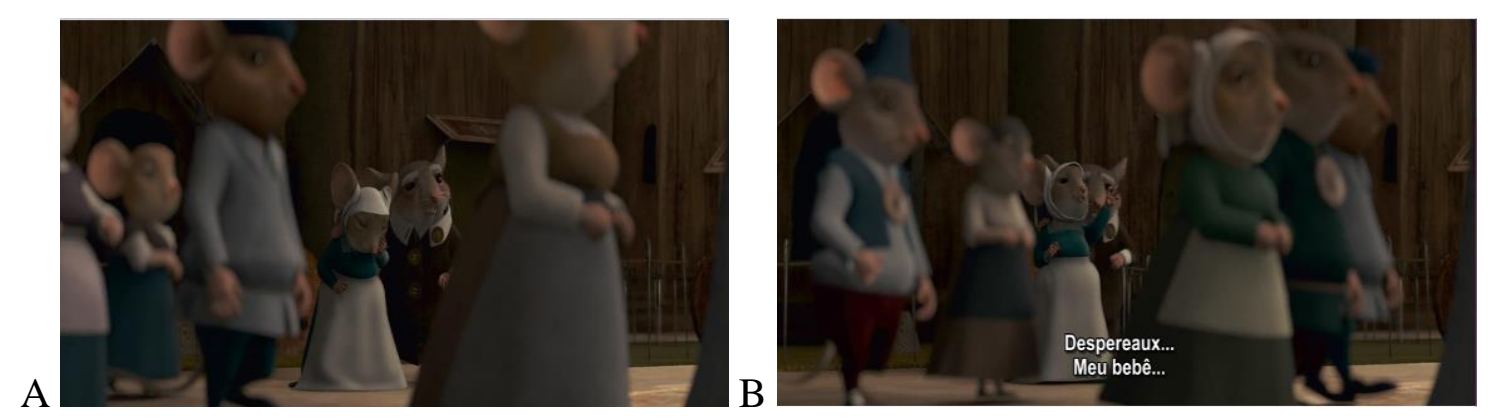

Figura 7 - Sentimentos de Lester e Antoinette.

Na narrativa literária, o camundongo é denunciado pelo irmão ao pai, membro do conselho. Não alegando inocência, é mandado ao calabouço e, desnorteado por ter não sido defendido pelos pais, Despereaux se choca ao perceber que um dos encapuzados que o estão levando para a morte é seu próprio irmão. Ele pede clemência, mas o irmão diz que regras são regras e fala em voz alta, como procedimento, a sentença do condenado: usar uma linha vermelha em volta do pescoço, cor escolhida para representar pena de morte.

Na animação, durante o julgamento, Furlough se encontra na plateia, assistindo a tudo de longe. A figura 8A, mostra seu pesar sobre a situação do irmão, e a 8B posição das mãos na hora de esperar a decisão do conselho como se tivesse esperança de que o irmão pudesse se salvar, mostrando-se consternado com até que ponto chegou a desobediência do irmão.

A
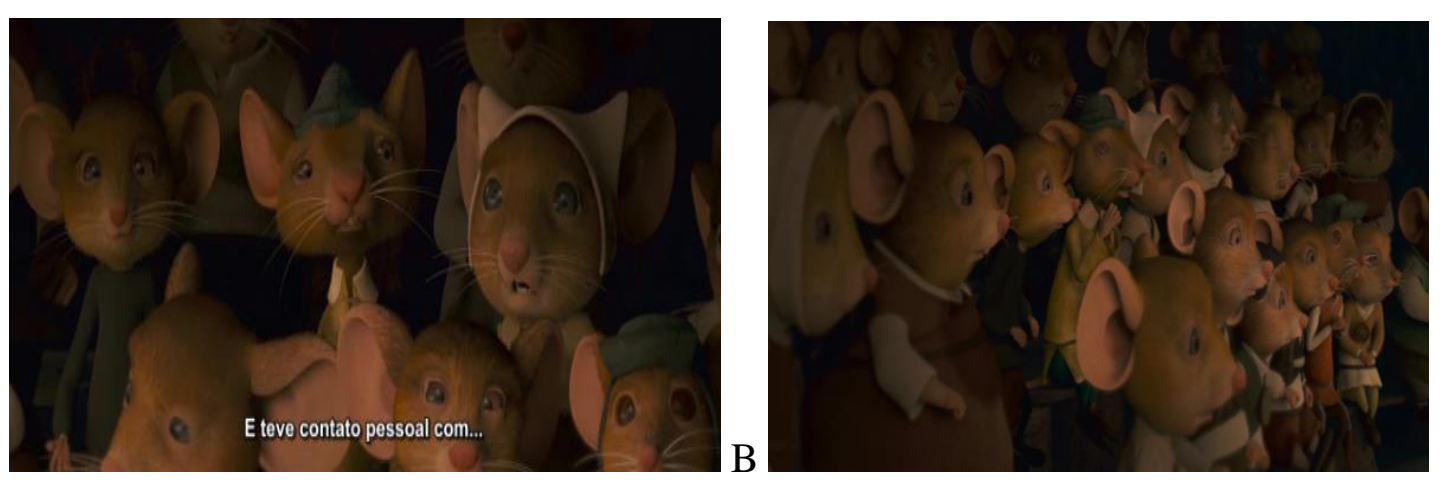

Figura 8 - O pesar de Furlough. 
Ele é sentenciado a descer ao calabouço, de onde ninguém jamais retornou. $\mathrm{O}$ responsável por cuidar das linhas que identificam as sentenças dos réus é um rato velho cego, antigo na profissão que já sabe a localização das cores. Mostra-se a cor da linha, vermelha, mas não é explicado o que ela representa, não ficando claro que ele será morto.
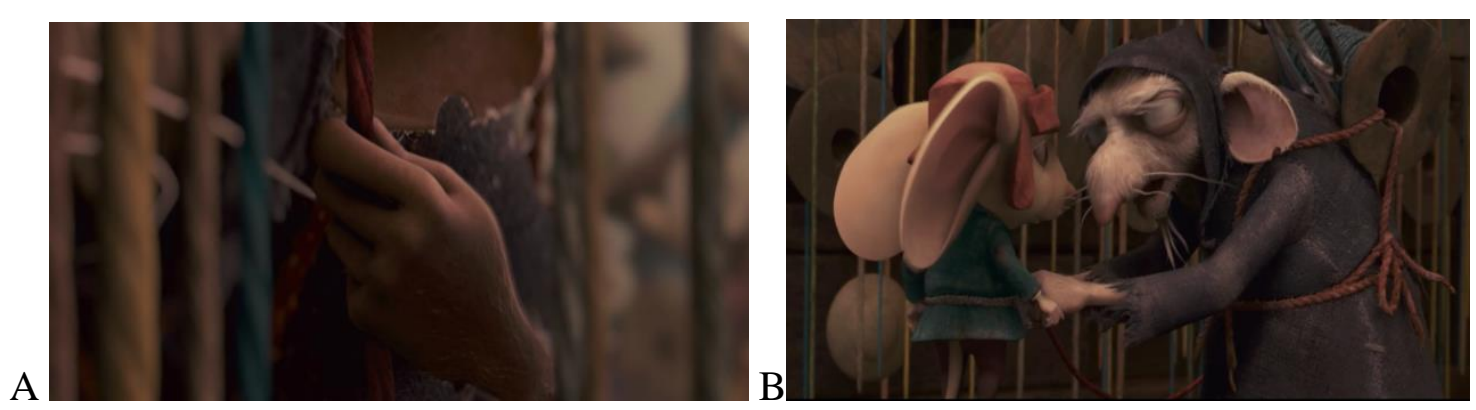

Figura 9 - Close na cor vermelha da linha.

Despereaux aparece no calabouço quase imperceptível aos olhos do espectador. Sua vulnerabilidade e solidão ficam evidenciadas por seu tamanho em relação ao local. Sua primeira reação é surpreender-se com a escuridão e evidências de morte que encontra por lá. Seu espírito aventureiro fez com que ele saia em busca de um caminho, até encontrar o carcereiro. Ele se apresenta como um cavaleiro e sugere contar uma história ao homem, que se irrita e o joga para as ratazanas. Roscuro, que já estava no calabouço, ouve a história e o salva de ser morto e juntos juram devoção à princesa.
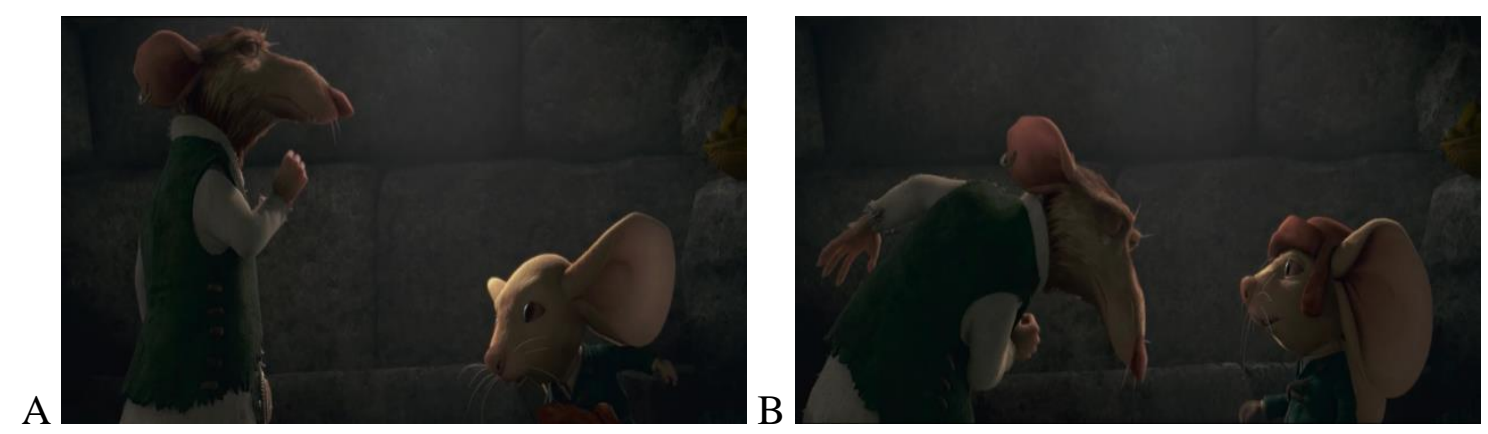

Figura 10 - Dois cavaleiros jurando devoção à princesa.

O modo como Despereaux se projeta nas histórias que lê faz com que sua coragem transcenda sua imaginação para sair em busca da princesa. Na cena a seguir, Despereaux aparece tentando lutar com uma agulha contra meia dúzia de ratazanas. Obviamente, em 
detrimento de seu tamanho e pela quantidade de inimigos, o camundongo tem de recorrer à astúcia, fazendo-os tropeçar e cair para vencê-los.

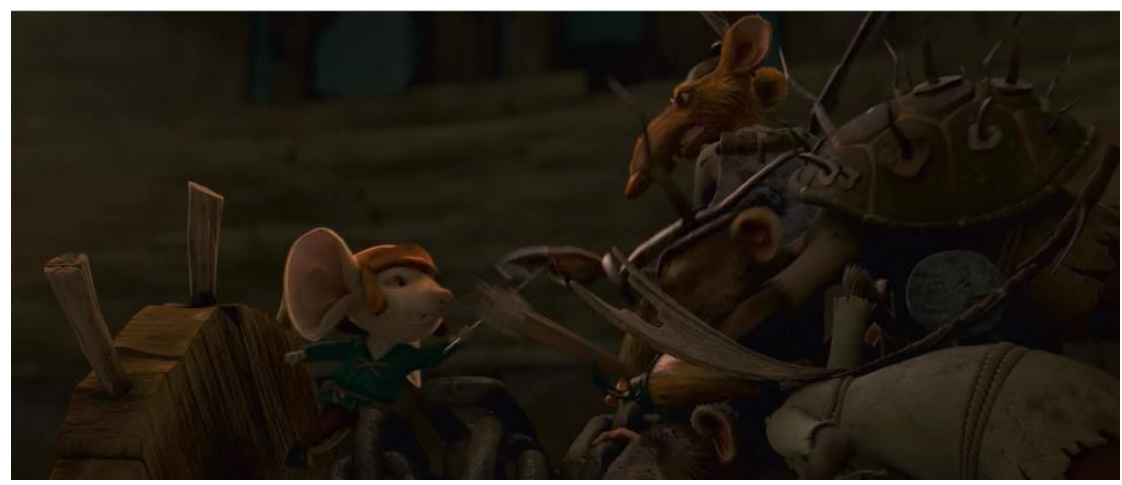

Figura 11 - A luta.

Quando tudo se resolve, Despereaux é reconhecido pelos membros, sendo aceito na comunidade, que passou a seguir suas ideias, dando início, agora, a um treinamento de coragem. A figura 12A, em Plano Conjunto, mostra todos aqueles que o julgaram indevidamente aplaudindo orgulhosamente os camundongos que passaram por cima de seus medos, enfrentando os perigos cotidianos. A 12B, em Plano Geral Aberto, mostra justamente seu irmão e os colegas que não davam valor ao seu modo de pensar fazendo o treinamento em ratoeiras.
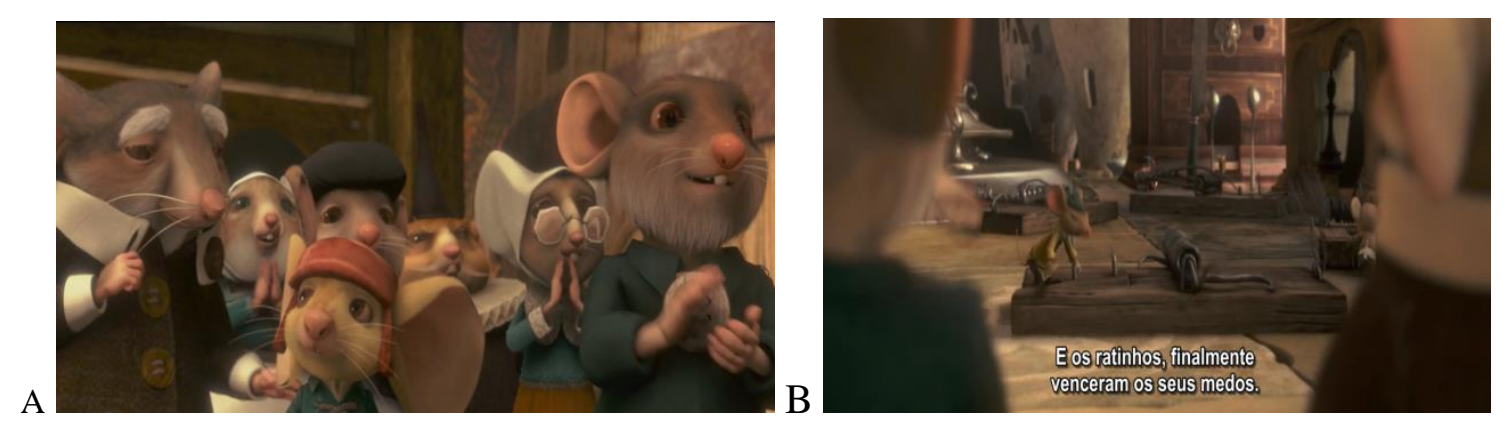

Figura 12 - Aceitação de Despereaux.

No livro e na animação, o personagem Despereaux é construído a partir de acontecimentos que ratificam seu lado humilde e corajoso. É interessante como a narrativa 
literária, por contar a história por meio do estímulo da imaginação do leitor, edifica e esclarece detalhadamente cada pensamento e sentimento vivenciado por ele.

Como não há possibilidade de se fazer uso de expressões faciais que exponham tais consequências, no livro, o efeito moral sobre a vida deste personagem é transmitido por meio das situações em que ele tem crises de consciência antes de tomar uma atitude impensada. Para que isso ocorra, mostra-se um contexto de injustiças sociais, frisados pelo narrador, fazendo com que tais atributos fiquem evidenciados ao leitor.

Sua sina se inicia com a forma com que é tratado pelos familiares desde seu nascimento, com descaso, deboche sobre sua aparência e condição e negligência. Seu próprio irmão o denuncia e o leva para a morte sem arrependimento em favor das regras e seu pai toca o tambor que determina sua sentença. A mãe, por sua vez, preocupa-se mais com sua aparência e se conforma com sua ida. Ele não tem amigos e a princesa Pea é a única que simpatiza com ele. Evidencia-se também seu lado destemido e justo, pois Despereaux mesmo perdendo sua cauda, passando a noite com dor, não desiste de salvar a princesa e cumprir o que prometeu. Herói inesperado de saúde frágil, que não tem atributos como força ou agilidade, contribui para que a história se resolva por meio de sua coragem e perseverança.

Na narrativa fílmica, sua redenção se dá pela comprovação de seus atributos aos membros de sua sociedade. Como já foi mencionado, nossa sociedade ocidental, cada vez mais, tenta instruir o indivíduo a respeitar o próximo e agir conforme preceitos morais. Com isso, ocorrem diversas elipses na animação que amenizam os atos dos personagens antagonistas, colocando-os como atitudes reprováveis, mas não cruéis ou frias. Ao contrário da obra literária, em que apesar de a família o trair para seguir as leis, o foco recai sobre a atitude dos personagens como pais e irmão, na animação, essa traição é atenuada pela justificativa do medo e da obediência cega a regras, que, na animação. Assim, há naturalmente uma reconciliação ao final da história e gestos que demonstram o orgulho e o respeito da família por Despereaux.

O papel do sistema escolar é evidenciado moldando os cidadãos desde a infância para prevenir desobediências futuras. O ensino escolar se faz tão presente e marcante na vida que, no final da trama, é necessário que os camundongos reaprendam, com teoria e prática, seu novo estilo de vida. Isso mostra à criança que na escola se aprende não só matérias escolares, 
mas a viver em sociedade, com julgamento e sabedoria; que a educação é primordial e é importante debater os assuntos atuais, estimular a criatividade e o desenvolvimento intelectual e não ficar preso a modelos antigos de ensino, em que os professores eram autoritários.

As elipses de conteúdo são motivadas por razões sociais. Existem diversos fragmentos que em respeito aos bons costumes e em decorrência dos tabus sociais são omitidos na tela. Eles podem ser total ou parcialmente escondidos por um elemento material. Ele pode também ser substituído pelo plano detalhe de expressões faciais. Ocorre também a substituição por um plano simbólico cujo conteúdo evoca o que se passa fora do enquadramento (MARTIN, 2013, p.101).

A obra literária volta sua crítica social para as relações interpessoais em detrimento de regras infundadas, ao passo que a obra fílmica abrange, como um todo, o que está errado em cada sociedade mostrada. Nas cenas em que Despereaux aparece, os planos utilizados, em sua maioria, salientam as expressões e atitudes de Despereaux em relação ao meio, sempre contrastando seu lado positivo como coragem, alegria, esperança com o medo, pessimismo e estagnação dos outros.

A tabela a seguir ilustra as principais diferenças encontradas na construção de Despereaux no livro e no filme: 


\begin{tabular}{l|l}
\hline Livro & Filme \\
\hline $\begin{array}{l}\text {-O pai é responsável por decidir sua sentença } \\
\text { de morte; }\end{array}$ & $\begin{array}{l}\text {-O pai o denuncia por medo das } \\
\text { consequências; }\end{array}$ \\
$\begin{array}{l}\text {-O irmão o denuncia e o leva pessoalmente } \\
\text { para a ser comido pelas ratazanas; }\end{array}$ & $\begin{array}{l}\text {-O irmão conta ao pai sobre as atitudes de } \\
\text { Despereaux, mas se arrepende; }\end{array}$ \\
\hline -A mãe simplesmente diz adeus ao filho; & -A mãe se despede do filho chorando; \\
\hline -Perde a cauda; & -Despereaux prova seu valor à comunidade. \\
\hline $\begin{array}{l}\text {-Perdoa os pais para tirar o peso de sua } \\
\text { consciência. }\end{array}$ & \\
\hline
\end{tabular}

Tabela 1 - Personagem Despereaux: livro e animação.

\subsubsection{Personagem Miggery}

Miggery, que nunca conheceu sua mãe, vive parte de sua infância com o pai. Em uma situação de extrema miséria, ele a entrega para que outra família cuide dela. A cena o mostra entregando-a para um casal, diretamente para a mulher, inexistente no livro. Ela aparece somente nesta cena, o que sugere que por estar deixando a filha aos cuidados de uma figura feminina, teoricamente, com instintos maternais, suaviza-se o abandono. Originalmente, ela é vendida a um homem estranho e solitário que a espanca e a força a trabalhar em sua fazenda. Um elemento que contribui para a amenização do ato é que, na adaptação, o tio é de fato seu parente e recebe um nome, Ned, o que humaniza a situação, pois sendo ele irmão do pai ou da mãe, há sobre o espectador a ilusão da naturalidade do apoio familiar diante de adversidades. 


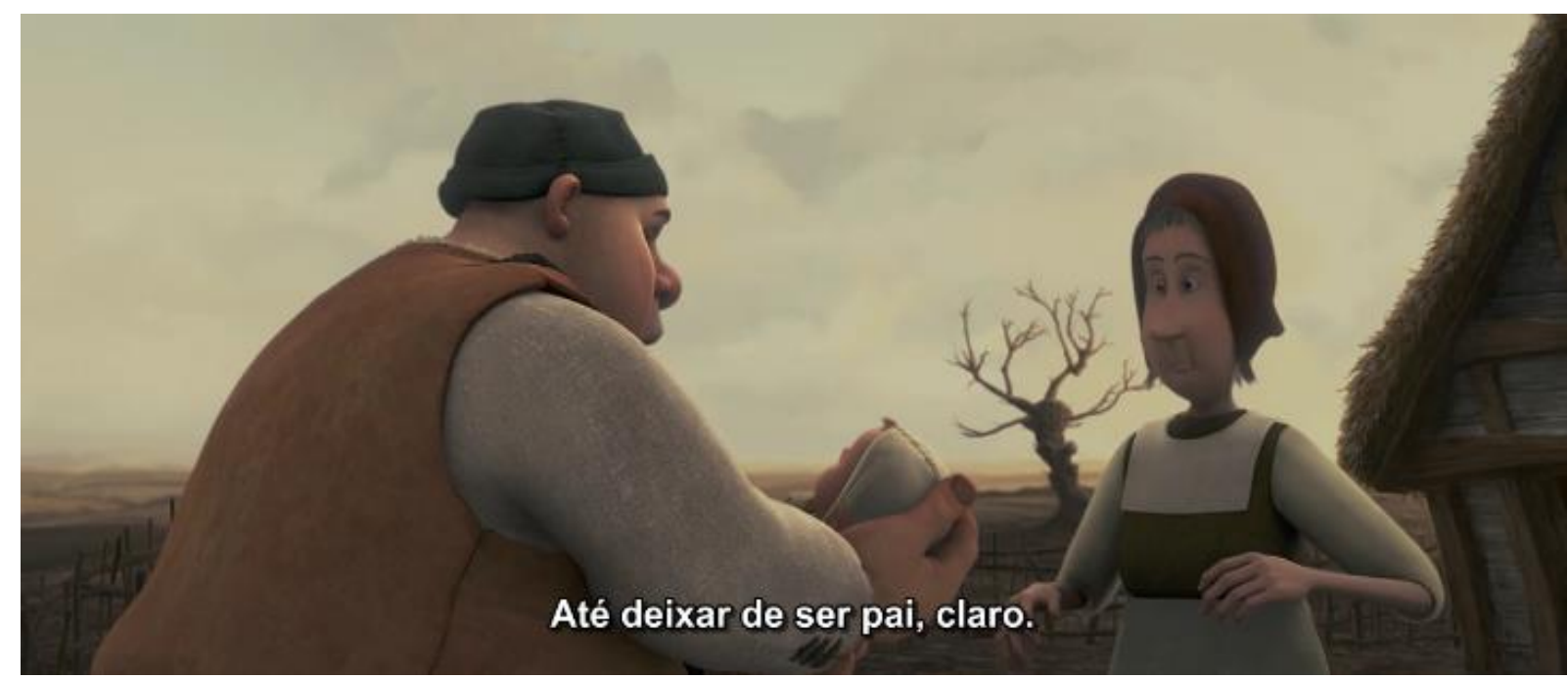

Figura 13 - Pai de Miggery entregando-a, ainda bebê, para uma mulher.

Os episódios fatídicos são sutilizados ao passo que seu abandono aparece de forma sofrida, representado pelo close up da expressão de tristeza do pai ao dar-lhe um abraço terno de despedida enquanto pede perdão.

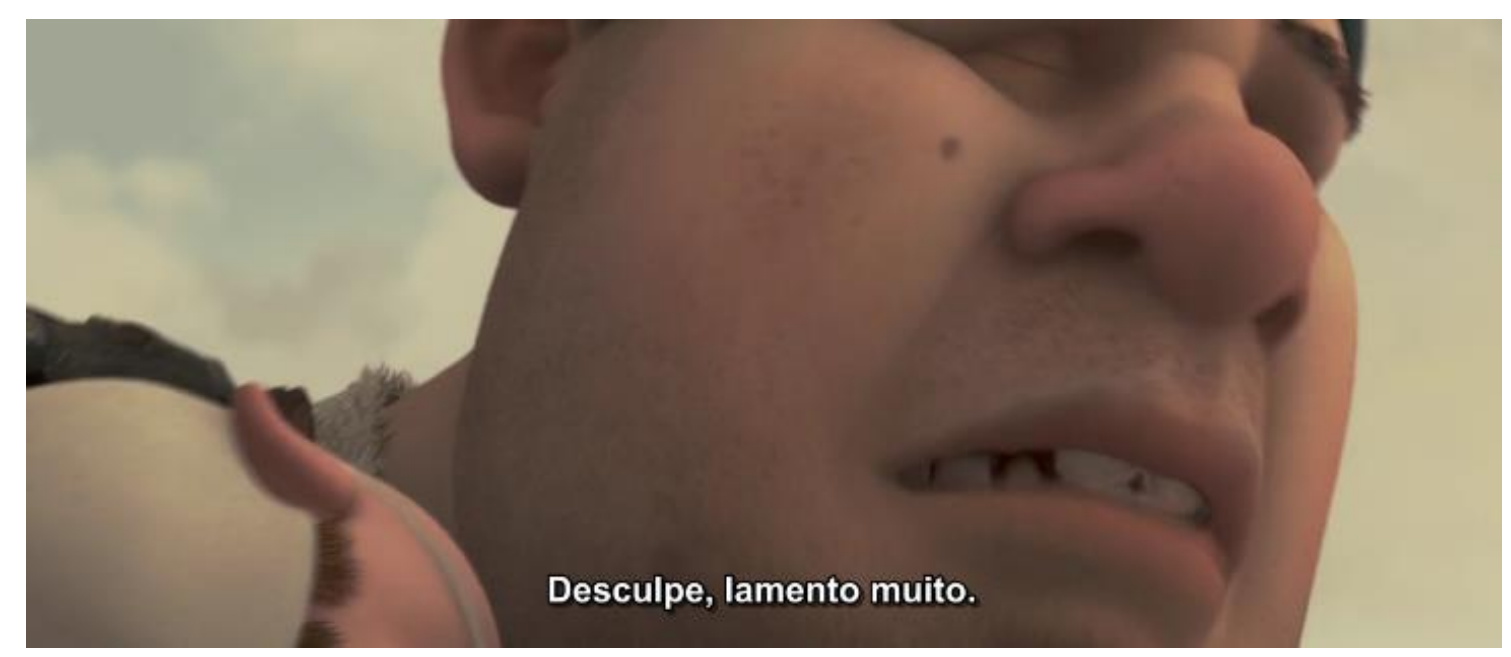

Figura 14 - Tristeza do pai de Miggery.

Os maus-tratos sofridos por ela são simbolizados por atitudes que a inferiorizam. Sua surdez é insinuada como tolice, irritando àqueles que ela não consegue ouvir. É sugerido que ela tenha alguma deficiência, mas não fica claro. A surdez, no caso, fica como uma possibilidade, como exposto na fala do tio: 

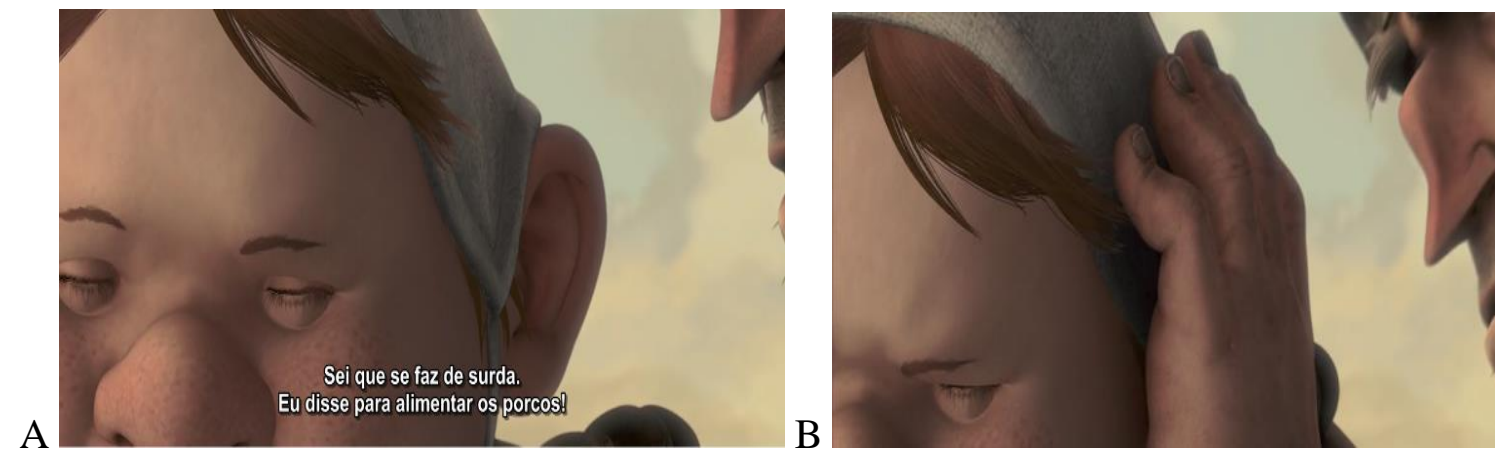

Figura 15 - Gritos do tio.

As Figuras 15A e 15B representam a suposta surdez de Miggery como resultante de gritos próximos ao seu ouvido. Nas duas cenas em que isso ocorre, tem-se, no mesmo enquadramento, um close do ouvido dela e a boca de quem grita somados à sua expressão. Sua dor é ressaltada por um som estridente e agoniante que acompanha a cena.

Miggery tem como característica marcante seu lado sonhador que se sobressai em contraste com as inúmeras dificuldades que enfrenta. Desde criança, ela se imagina vivendo no castelo, contudo, cada vez que expõe suas aspirações e desejos, é depreciada por aqueles que a rodeiam. Os infortúnios da vida de Miggery são amenizados pela narradora, na animação, ao frisar seu lado sonhador, sempre com esperança de um futuro melhor:

\footnotetext{
Miggery Sow limpa excremento de porco desde que lembra. Seu tio Ned colocou-lhe uma pá nas mãos assim que ela conseguiu segurar uma. Mas acabou tudo bem, porque ela fez amizade com os porcos. Na verdade, Miggery Sow conseguia ver seu futuro claramente, conseguia ver a tiara, seus belos vestidos, as criadas. E quando as coisas ficavam ruins de verdade na fazenda, conseguia ver o momento em que iria, finalmente, ficar livre de tudo isso.
}

Quando chega ao castelo, ela é retratada sozinha, pequena em relação a um cômodo gigantesco sem mobília. Aqui, subentende-se que mesmo chegando mais perto de seu sonho de ser princesa, ela continua sentindo-se solitária e abandonada. 


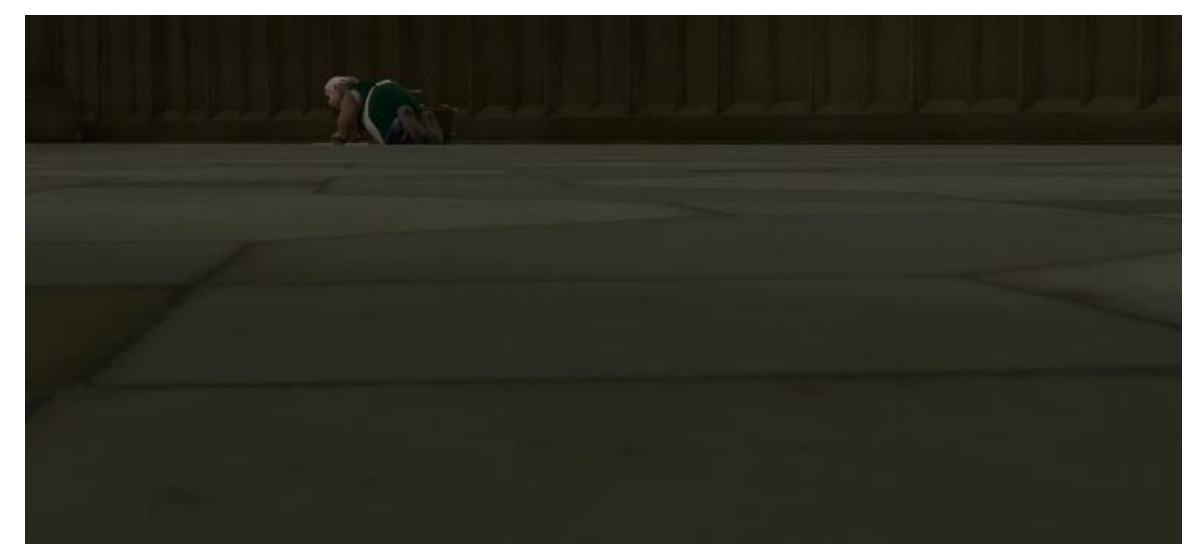

Figura 16 - Solidão de Miggery.

Os sonhos de Miggery se apresentam como inatingíveis, por isso parecem mais distantes. No enquadramento, o sentimento fica evidenciado pela posição de seu rosto, voltado para seu desejo, que por sua vez, são destacados de modo turvo. Na figura 17A, Miggery olha para o castelo, imaginando-se com uma vida de princesa e na 17B, percebendo ainda estar longe de seu sonho, admira Pea no quadro. Nesta cena a narradora acrescenta:

Há todo o tipo de princesas. Algumas nasceram assim, algumas através do casamento e algumas, estão destinadas a ser princesas apenas em pensamento. Mais cedo ou mais tarde toda menina deseja ser princesa.
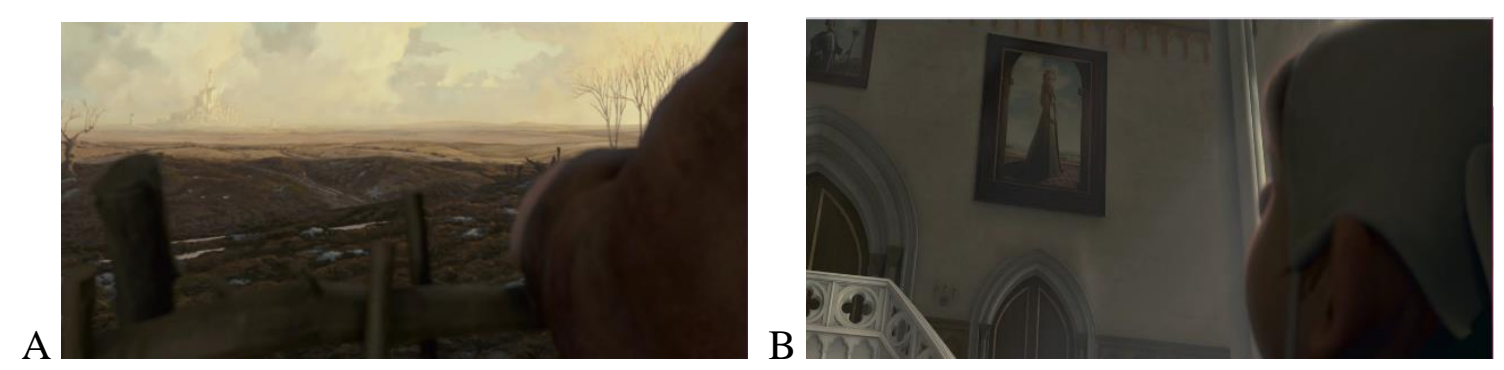

\section{Figura 17 - Sonhos de Miggery.}

Como efeito bola de neve, Miggery ao elogiar a coroa da princesa, é destratada por Pea, que desconta sua frustração na criada. Por estar de costas, ela não vê que a princesa ficou triste pela forma como a tratou e vai magoada para seus aposentos. 


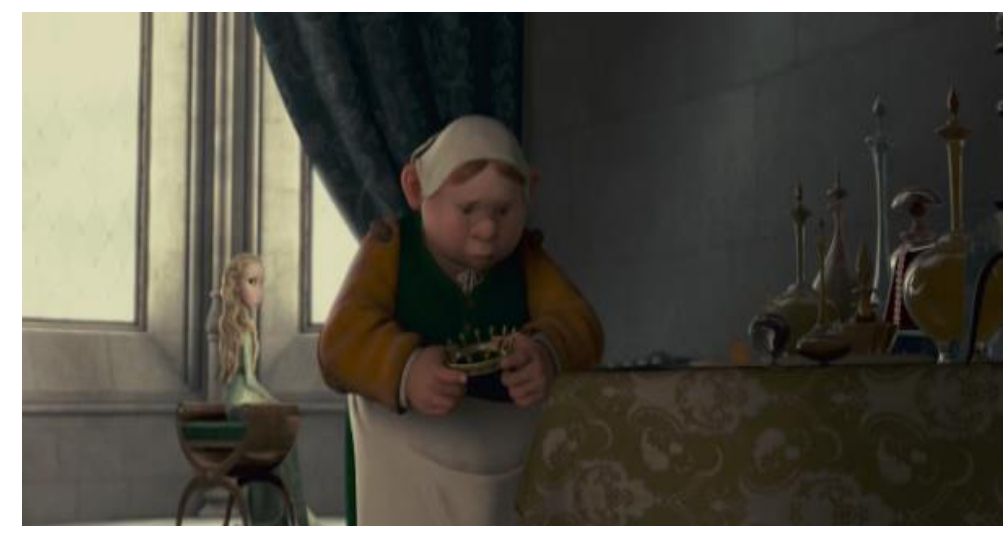

Figura 18 - Tristeza de Miggery.

Roscuro, em Plano Detalhe, aproveitando-se de sua vulnerabilidade, convence-a a se vingar para tomar o lugar da princesa. Em 19B, o up close em seu olhar mostra o momento exato em que sua mágoa se torna rancor.
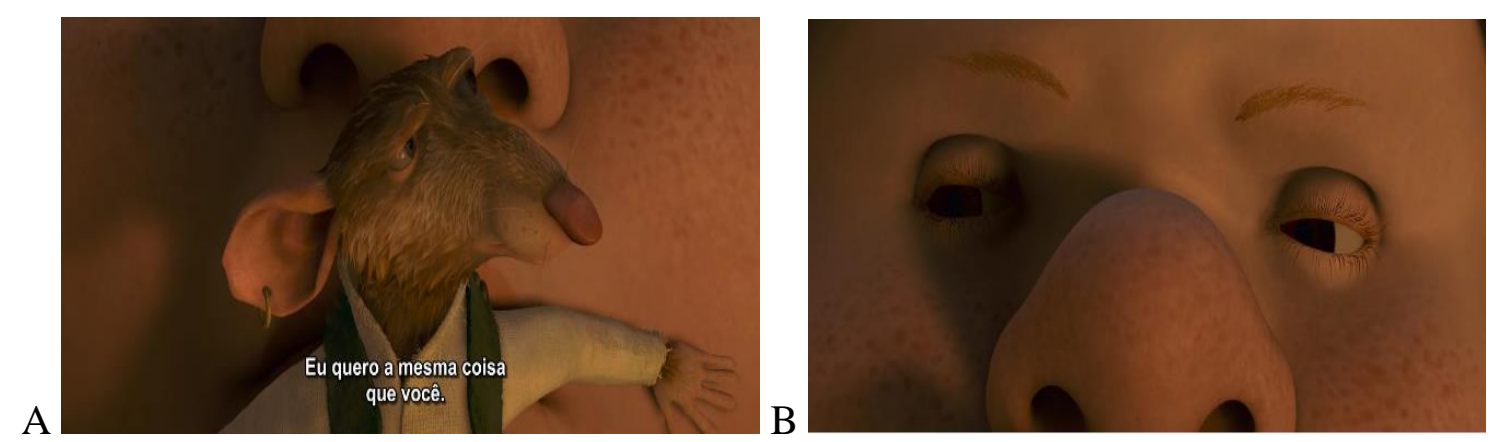

Figura 19 - Mudança de sentimento.

Quando Miggery, enraivecida, está indo sequestrar a princesa, a narradora ressalta o desconhecimento de Miggery sobre seu real valor. Depois de aguentar tanta tristeza, a forma como Pea lhe trata é o que ultrapassa seu limite de tolerância.

Sabe, a dor é uma coisa engraçada. A mesma coisa que faz uma pessoa ficar brava, pode fazer outra se amargurar. Gregory sempre disse que ela tinha coração demais, e que foi por que isso que tiveram que colocar um pouco dele no exterior. Mas, vamos ser honestos, é difícil ver algo nas suas costas. Na verdade, pode-se ter um bom coração e nem mesmo saber disso. 

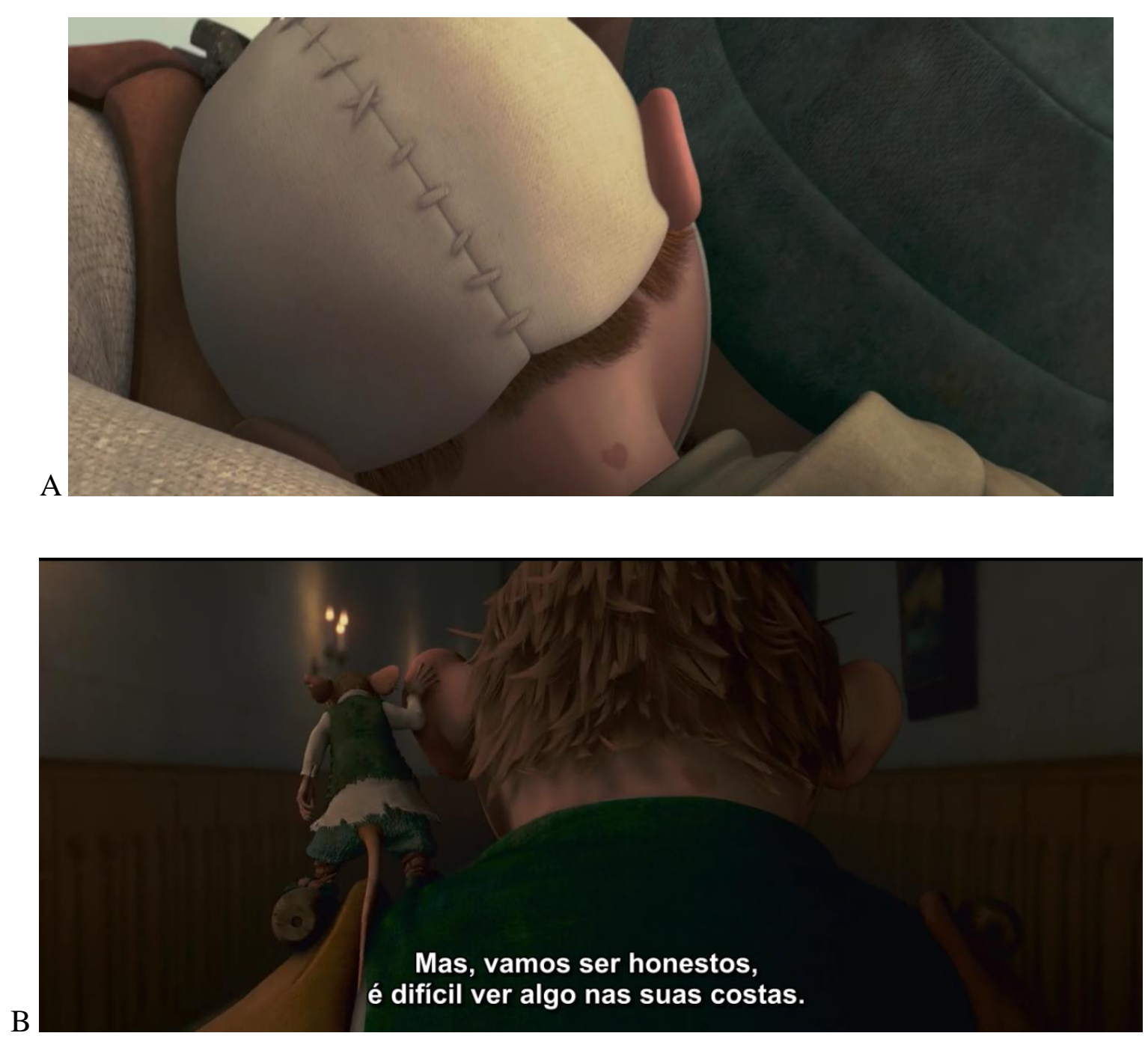

Figura 20 - Marca de nascença no pescoço de Miggery.

Miggery rapta a princesa prendendo-a no calabouço, mas é trancada em outra cela por Roscuro e, após gritar por horas, chama a atenção de Gregory, que a vê de costas e reconhece sua marca de nascença. Ele pede perdão e a leva para casa e realiza seu sonho de ser tratada como princesa. 


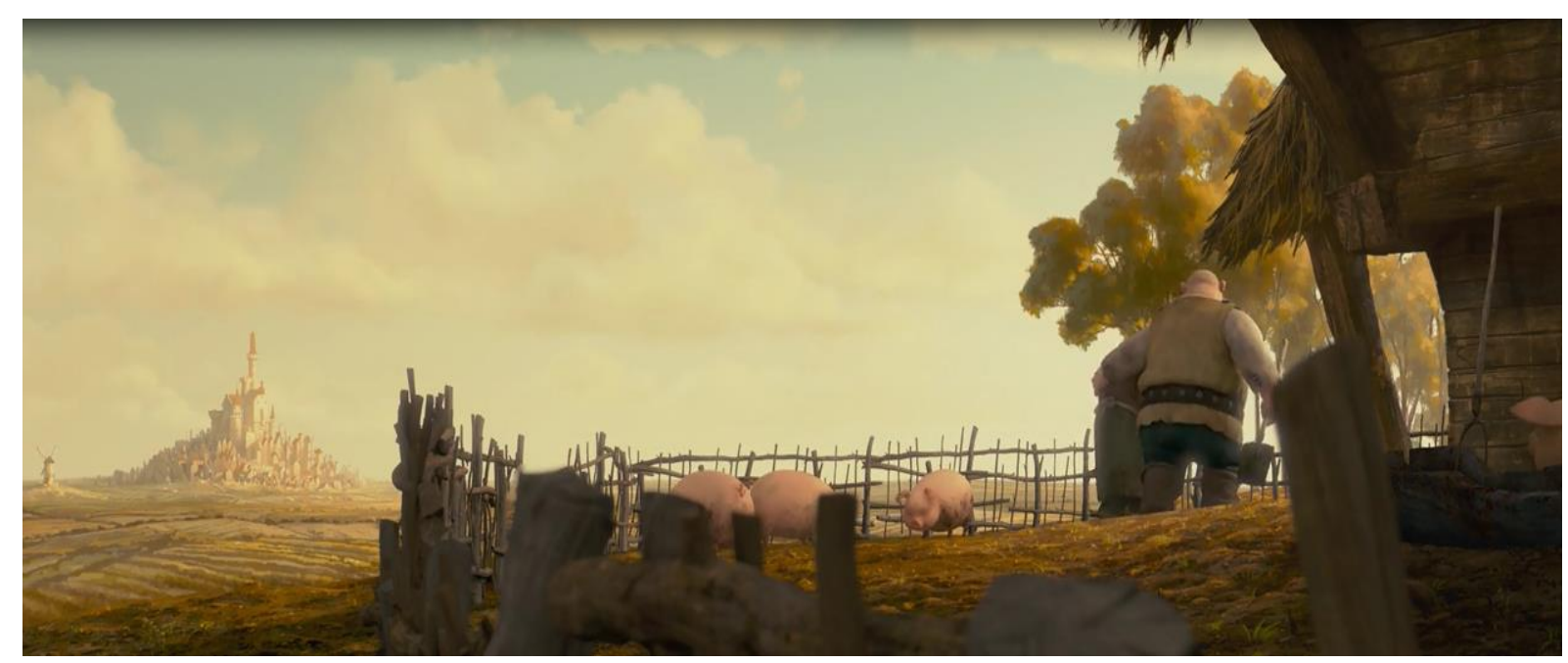

Figura 21 - Miggery reencontra seu pai.

A cena em Grande Plano Geral, desta vez, a mostra com o pai e os porquinhos de volta para casa, sem seu tio, e o castelo ao fundo em uma visão mais nítida, em que se subentende fácil acessibilidade, como um anexo ao seu lar. Miggery se reconcilia com a princesa que a deixa usar a coroa para que ela se sinta como tal.
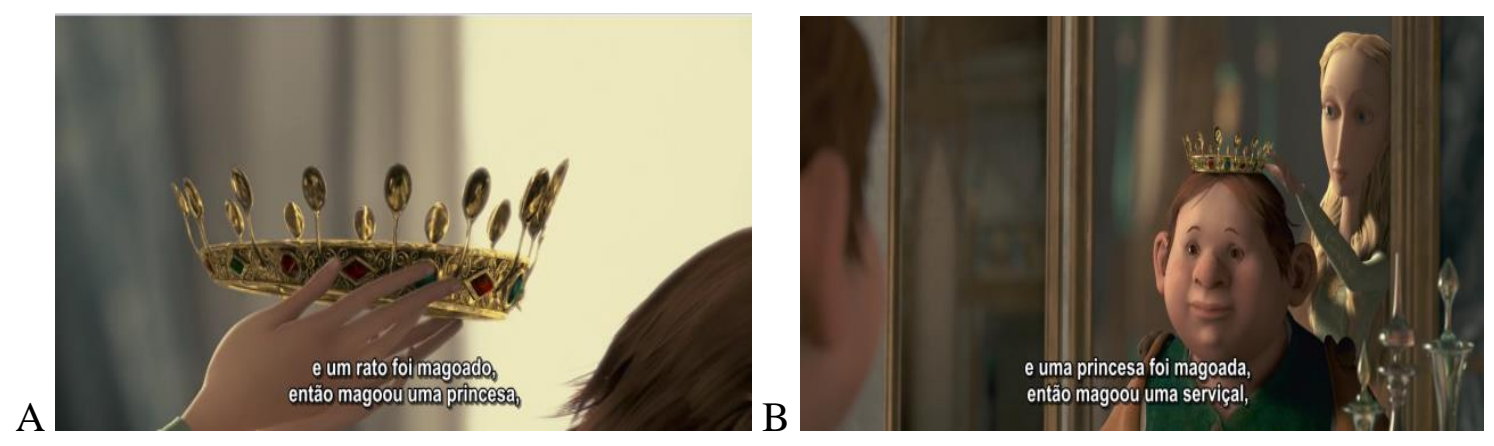

Figura 22 - Coroa real.

Miggery Sow é uma personagem que, em meio a constantes desilusões, mantém-se sonhadora. Muitas partes de sua história na narrativa literária foram romanceadas na animação, como o fato de ela ser vendida ter sido substituído por uma situação em que seu pai, por falta de recursos, teve de deixá-la com os tios; as surras responsáveis pela sua deficiência física aparecem como gritos próximos ao seu ouvido que a incomodam; e a péssima forma como sua mãe a tratava antes de morrer ser suprimida e a narrativa ser voltada para a parte em que ela se torna órfã. 
É interessante destacar que a personagem Miggery, apesar de ter uma deficiência e não se enquadrar nos padrões de beleza estabelecidos para as protagonistas das histórias, consegue a simpatia do leitor mediante a descrição de todos os fatores infelizes em sua vida, ao ponto de causar um desejo de que ela tenha o seu tão sonhado final feliz.

No livro, Miggery é inconsequente e segue comandos sem questionar, motivo pelo qual amputou a cauda de Despereaux a mando da cozinheira e seguiu as instruções de Roscuro para tomar o lugar da princesa. Sua personalidade na obra fílmica é lapidada. Sua vitimização e o sofrimento do pai ao entregá-la contribuem para que se crie empatia pela personagem. De acordo com Martin, a imagem fílmica desencadeia no espectador um sentimento de realidade capaz de suscitar crenças que vão desde a interação com a obra até a identificação com os personagens. O realismo oferecido pela imagem está diretamente relacionado à visão artística do realizador (MARTIN, 2003, p.28-32).

Esse carisma obtido em prol de sua condição faz com que ela seja duplamente gratificada ao ser "coroada" por Pea e tratada como princesa por seu pai. De modo geral, os planos utilizados na trajetória de Miggery expõem detalhes que representam seu estado de espírito e quem ela realmente é, como o destaque à coroa, a mão do pai sobre seus ombros, sua expressão de ódio e, posteriormente, de felicidade ao final da história.

Contudo, apesar de representar "fielmente" acontecimentos, a imagem não consegue indicar o real sentido da cena. Ela por si só é carregada de ambiguidade e não nos permite conhecer o tempo de ação. Daí a necessidade do comentário, ou narração aliado à função do contexto fílmico criado pela montagem, que, paralelo a ela ocorre a função do contexto mental do espectador, que reage a partir dos seus gostos, concepções morais, políticas, culturais, preconceitos e ignorâncias (idem, p.34).

Observa-se que a palavra é apenas um constituinte da imagem, sendo submetida à planificação, e a montagem como um todo, é o elemento mais específico da linguagem cinematográfica (idem, p.219). Por isso, os atos indevidos de Miggery são justificados pela narradora e surgem juntamente ao enquadramento da mancha em formato de coração no pescoço da criada para explicar que ela mesma não conhecia seu valor. 


\begin{tabular}{l|l}
\hline Livro & Filme \\
\hline -É objeto de desdém de sua mãe; & -É órfã de mãe; \\
-Se torna órfã de mãe aos 6 anos; & -Em uma cena dramática, é levada pelo pai \\
-É vendida pelo pai; & para ficar aos cuidados de seu tio, intitulado \\
-Apanha constantemente do homem que a & Ned; \\
comprou; & -Ned grita constantemente em seus ouvidos, \\
-O homem pede que ela o chame de tio; & o que a deixa parcialmente surda; \\
-Torna-se parcialmente surda e tem as & -Possui uma mancha em forma de coração \\
orelhas deformadas devido às surras; & em sua nuca, como prova de sua essência \\
-Corta a cauda de Despereaux com um & boa; \\
cutelo; & -Apenas aceita o plano de Roscuro quando a \\
-Sequestra a princesa a mando de Roscuro; & princesa a desrespeita; \\
-Reconcilia-se com o pai. & -Reconcilia-se com o pai. \\
& \\
\hline
\end{tabular}

Tabela 2 - Construção da personagem Miggery no livro e na animação.

\subsubsection{Personagem Roscuro}

No início da história, a narradora começa mencionando indiretamente que não se deve aceitar cegamente o que dizem. Enquanto narra, as cenas que contradizem a sabedoria popular surgem em cena.

Era uma vez, um camundongo corajoso, que amava honra e justiça e sempre dizia a verdade. Não, esse não é ele. Essa é uma ratazana. E todo mundo sabe que há uma grande diferença entre um camundongo e uma ratazana. Primeiro, ratos detestam a luz. Passam a vida na escuridão. Também temem as pessoas e é por isso que são furtivos o tempo todo. E quanto a contar a verdade, isso é impossível porque, como todos sabem, ratazanas não falam. 

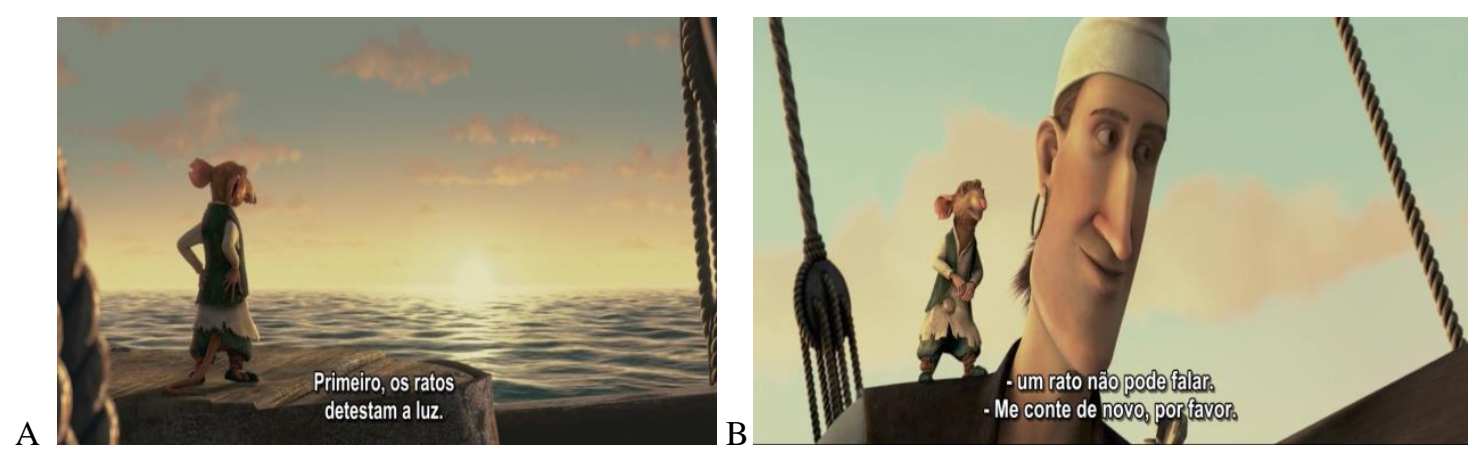

Figura 23 - Chegada à cidade.

Roscuro é um rato de navio, que chega à cidade com seu grande amigo viajante. Ele fica fascinado com a história que ouviu sobre a sopa da cidade de Dor ser mágica. Eles visitam o reino enquanto ocorre o festival da sopa. Todos se divertem e Roscuro, maravilhado com o aroma, entra no castelo.

Roscuro sente ser rejeitado quando, ao subir no lustre, localizado acima da mesa de jantar, cai acidentalmente na sopa da rainha. A reação de Pea é o que provoca sua tristeza e, posteriormente, ao ser tratado novamente por ela da mesma forma, este sentimento transforma-se em ódio.
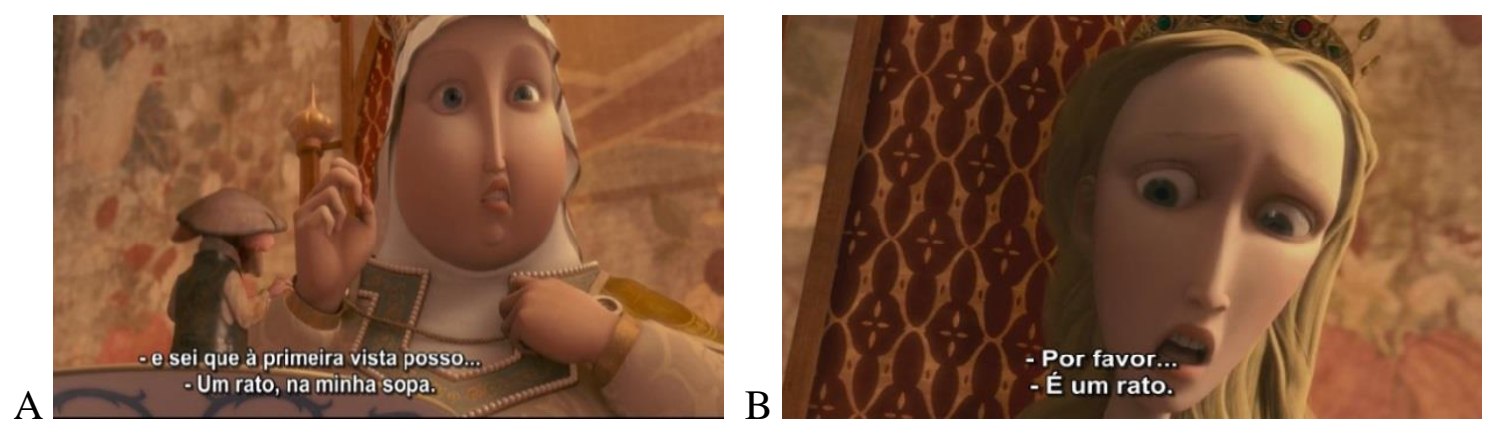

Figura 24 - Susto da Rainha e da Princesa.

O coração de Roscuro é despedaçado ao perceber que é alvo de extrema repulsa. A rainha literalmente morre de nojo e seu trauma ocorre quando, por meio do Plano Detalhe, ele vê o pavor nos olhos da Princesa Pea e as palavras de repulsa saindo lentamente de sua boca. 

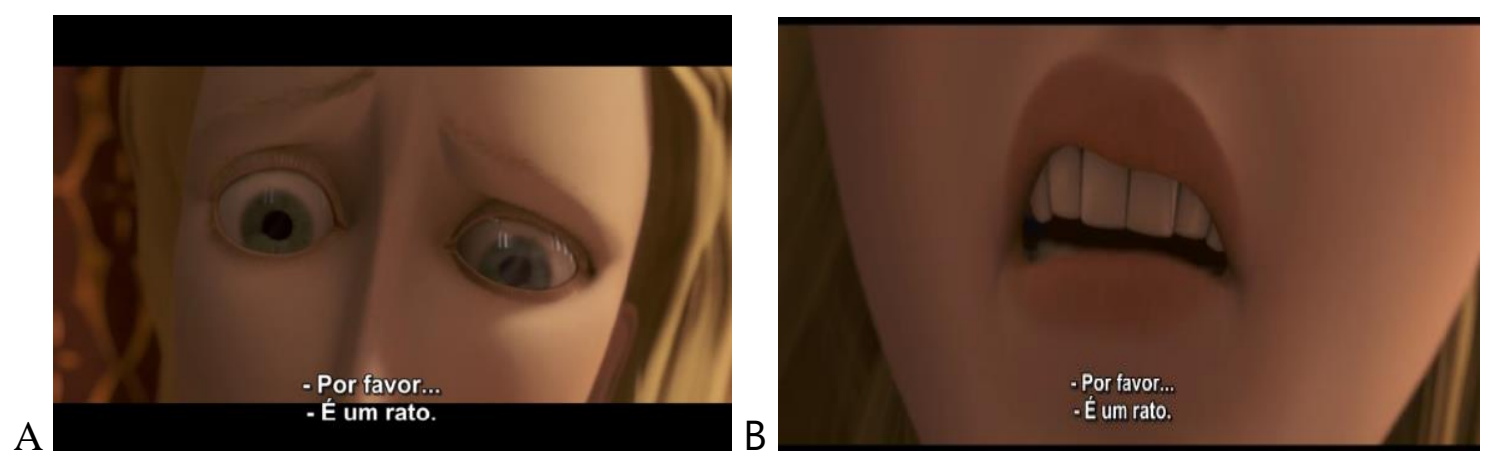

\section{Figura 25 - Repulsa da Princesa.}

Por ser um personagem originalmente bom, o grau de violência empregado para tentar exterminá-lo a qualquer custo, mesmo tendo pedido perdão, faz com que seu rancor se torne ainda maior, planejando vingança. Na figura 26B, o Plano Ponto de Vista - PPV com a câmera lenta, somada ao posicionamento de câmera em contraplongée, aparece como um artifício capaz de imprimir à cena uma atmosfera de tensão. Transmite-se ao espectador sua sensação de medo, fragilidade e surpresa com a reação da princesa, que além de não aceitar suas desculpas, tenta matá-lo.
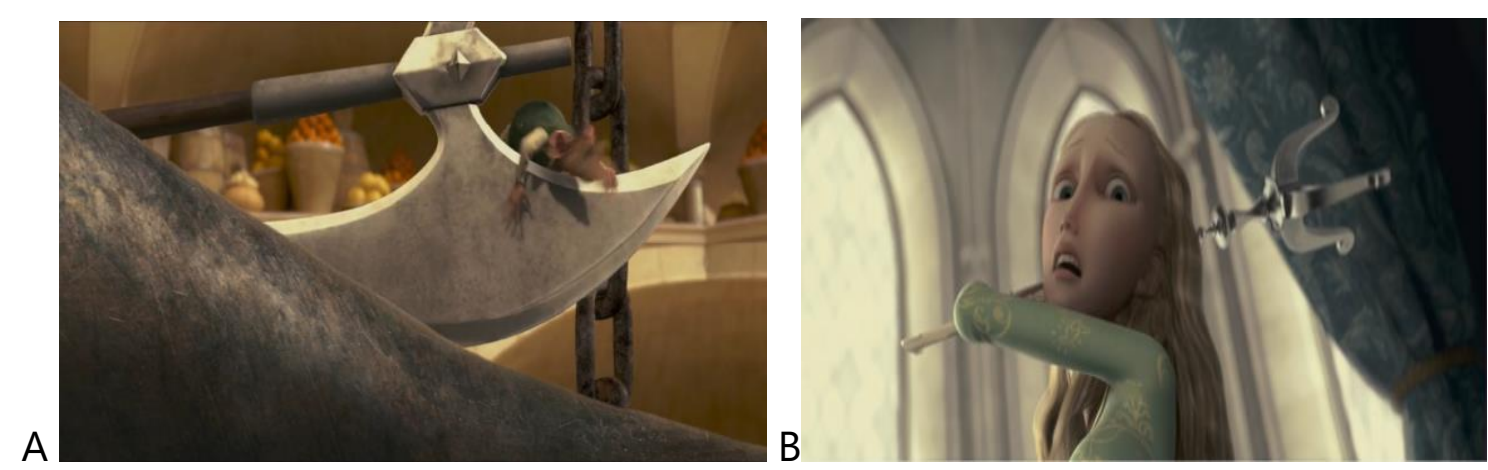

Figura 26 - Violência contra Roscuro.

Na cena da morte da rainha, o amigo marinheiro, não conseguindo encontrá-lo, vai embora e Roscuro, que acabou de ser humilhado, ao perceber que fora deixado, sente-se desolado, tornando-se vulnerável aos guardas, que o acertam com uma cebola e, ao tentar fugir, sem mais forças, cai em um vão direto para o calabouço. Na figura 27, ele olha o amigo 
indo embora. O foco está em Roscuro, que observa o navio se afastar cada vez mais, condensando-se ao fundo na cena.

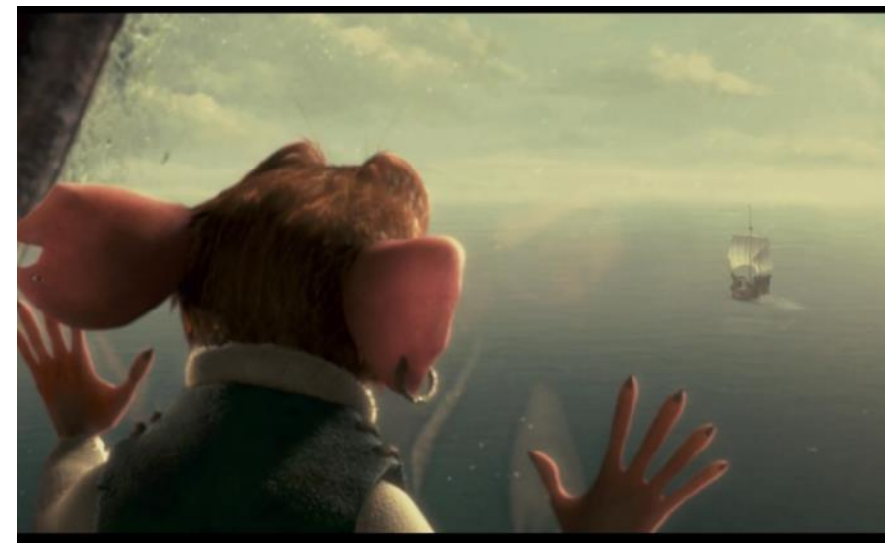

Figura 27 - Navio partindo.

Desolado, ele chora pela tragédia que acabou de acontecer. Botticelli surge e o ampara convencendo-o de que ele está na comunidade a que realmente pertence e que irá se acostumar com a escuridão. Ele aceita morar no calabouço e fica horrorizado com as outras ratazanas.

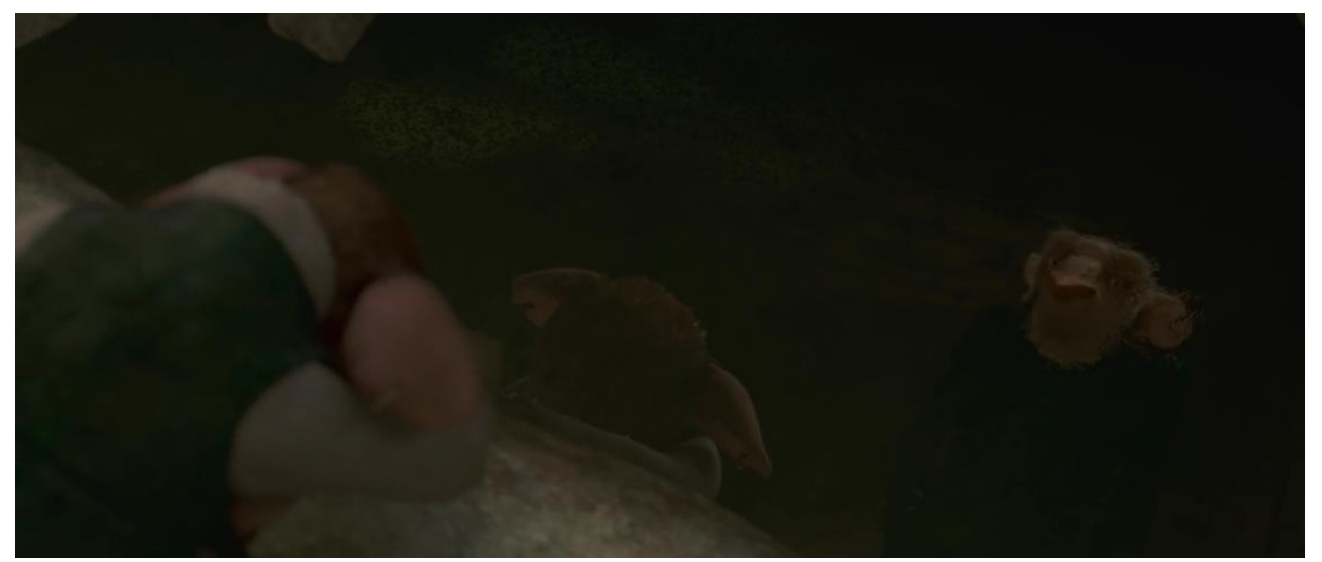

Figura 28 - Roscuro chorando.

A figura 29 mostra Botticelli e um comparsa observando e falando pelas costas de Roscuro sobre as dificuldades que terão em fazê-lo agir e pensar como os outros, submissos ao poder de Botticelli. Aqui, mostra-se a hierarquia e a imposição de valores sobre um novo membro nesta comunidade. 


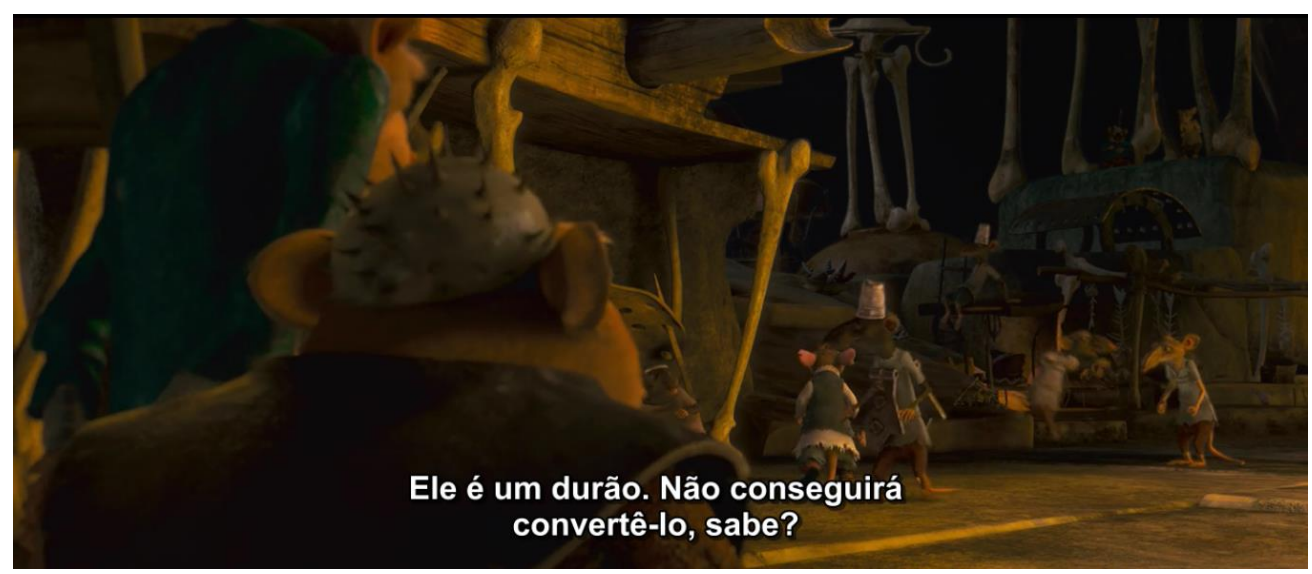

Figura 29 - Dificuldade em integrar-se.

Por ser o personagem que mais tem conflitos internos, cada sensação de Roscuro é evidenciada por closes em suas expressões. Na figura 30A e a 30B pode-se notar o contraste entre fortes sentimentos que demonstram estar horrorizado e maravilhado no mesmo cenário, o calabouço, mostrando que consegue ter esperança apesar de estar no pior dos lugares.
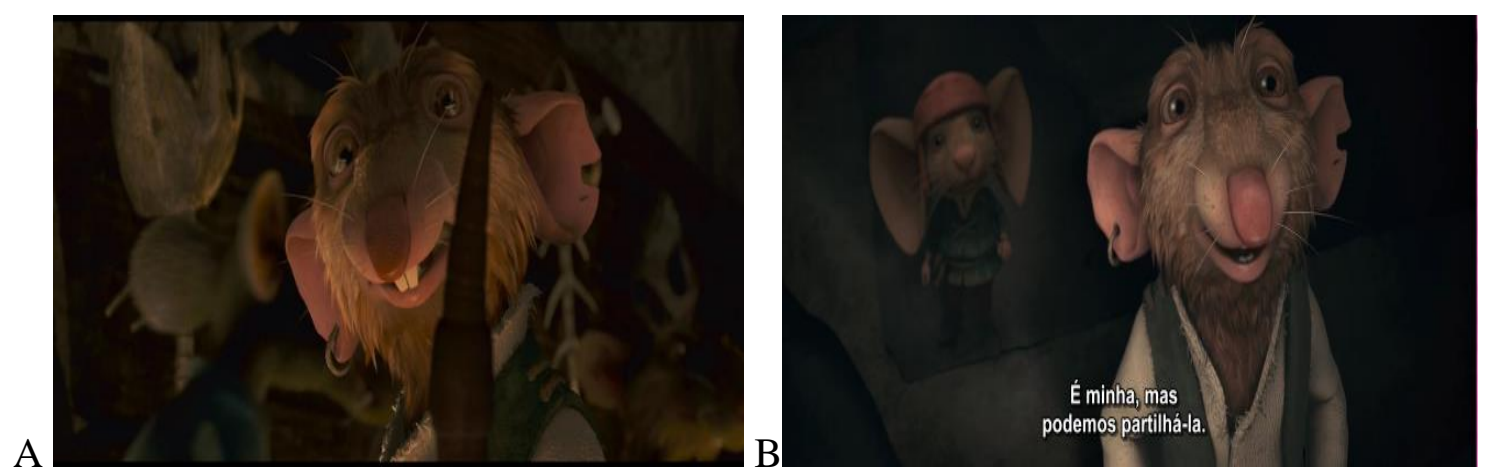

Figura 30 - Expressões de Roscuro.

Antes de Roscuro colocar em prática seu plano de vingança, o narrador na animação justifica o motivo de sua dor de forma dramática. A seguir, tem-se em Plano-sequência sua tristeza transformando-se em ódio: 

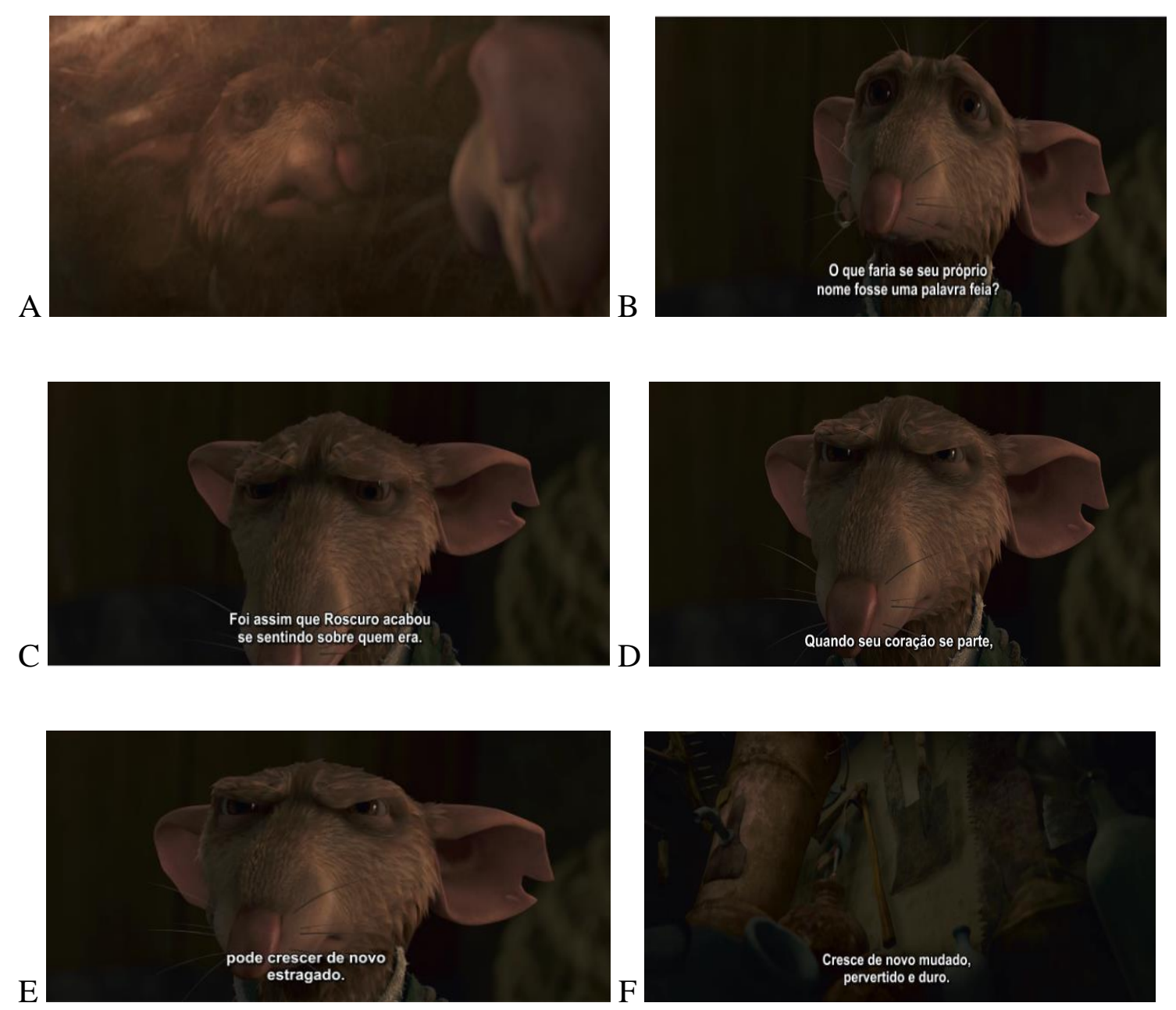

Figura 31 - Tristeza de Roscuro transformando-se em ódio.

Roscuro mais uma vez tem sua expressão facial em destaque como prova de seu real arrependimento. Sua reconciliação com a princesa, aqui, ocorre quando eles se entreolham e Roscuro percebe sua injustiça. Quando ele se desculpa, ela o interrompe e diz que é ela quem deve se desculpar. Nisso, entra a narradora explicando como aquele sentimento forte de vingança e raiva consegue se esvaecer.

Lembra quando dissemos que a amargura era a coisa mais forte que uma pessoa poderia sentir? Bem, não é. É o perdão. Porque um simples ato de perdão pode mudar tudo. 


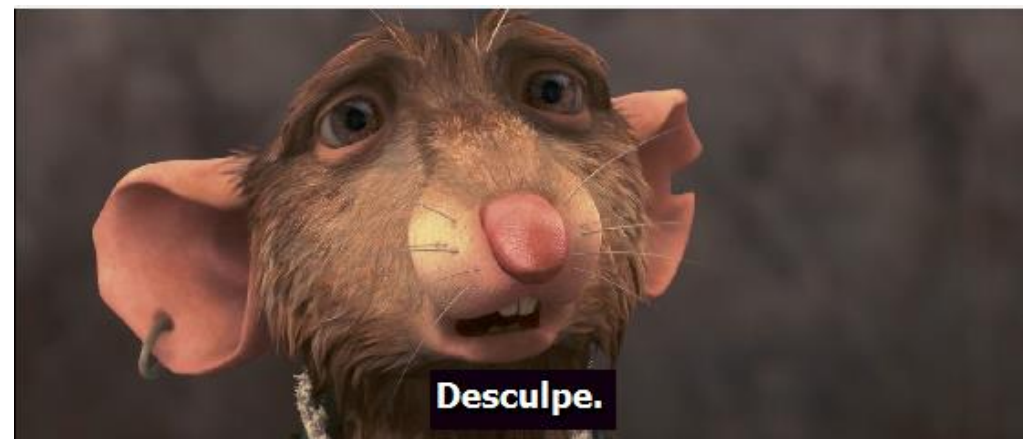

Figura 32 - Roscuro pede perdão à Princesa Pea.

No final, utiliza-se o Travelling em Grande Plano Geral. Na cena, aparece primeiro o castelo e a câmera vai se distanciando até mostrar o personagem e sua localização em relação ao castelo. Esse recurso, usado nos mesmos cenários em que sua história se inicia, demonstra que, assim como Miggery, após os problemas serem resolvidos, ele retoma sua vida, seguindo seu destino e ainda assim, mantendo seus laços afetivos com a cidade de Dor.

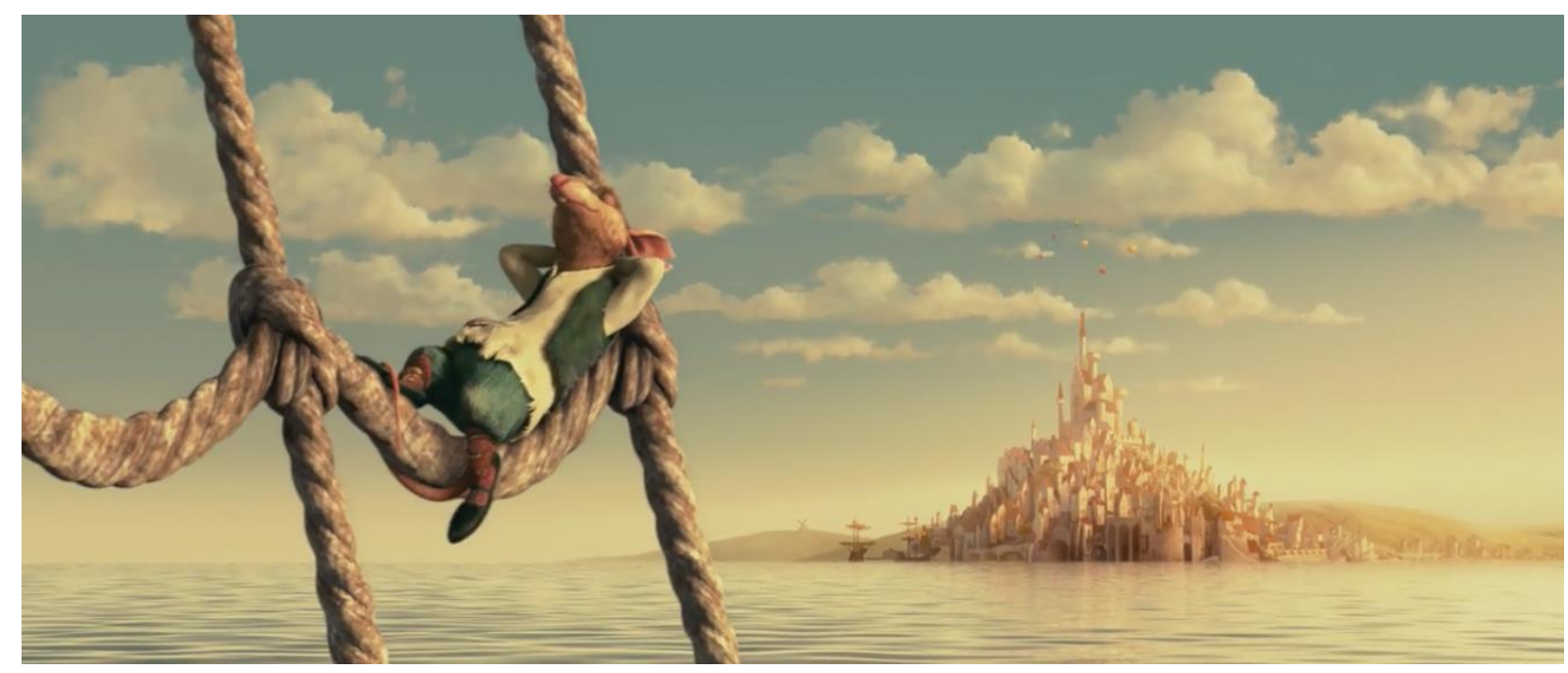

Figura 33 - Roscuro consegue liberdade e retorna ao navio.

Roscuro é uma ratazana que, independentemente dos acontecimentos, tenta, a todo custo, ter contato com a luz. Na narrativa literária, ele, orientado por Botticelli, faz mal ao prisioneiro e, ao ser tratado de maneira hostil pela princesa, instantaneamente cria em si um desejo de vingança. A partir de então, alimenta sua raiva e planeja usar a força física de Miggery para sequestrar a princesa. Os únicos indícios de ambivalência em sua personalidade são sua paixão pela luz e o pedido de desculpas no final. Mesmo recebendo o tratamento dos 
demais protagonistas, a narradora explica que, quando se tem uma grande decepção, dificilmente, volta-se a ser como era antes.

$\mathrm{Na}$ animação, Roscuro é uma ratazana de navio, satisfeita com a vida que tem, que chega à cidade e acidentalmente causa a morte da rainha. Ele primeiro se entristece com a situação e chora. Mesmo em meio à escuridão, ele não se deixa manipular pelas regras locais e cria um lugar para viver onde consiga obter a luz que costumava ter.

Os planos que envolvem a vida de Roscuro demonstram seus sentimentos por meio do destaque às suas expressões faciais: seu espanto com a forma como aquela sociedade vive e se porta, seu olhar de amor e esperança para a luz do sol, e sua mudança de perspectiva ao quase ser morto pela Princesa Pea. Essa transição progressiva em sua personalidade ocorre de modo que o espectador entenda suas motivações e perceba a relação entre causa e consequência. Aqui, ele é merecedor de um final feliz e tudo volta a ser como era, com sua vida no navio, mas agora, com um lar em terra firme para visitar.

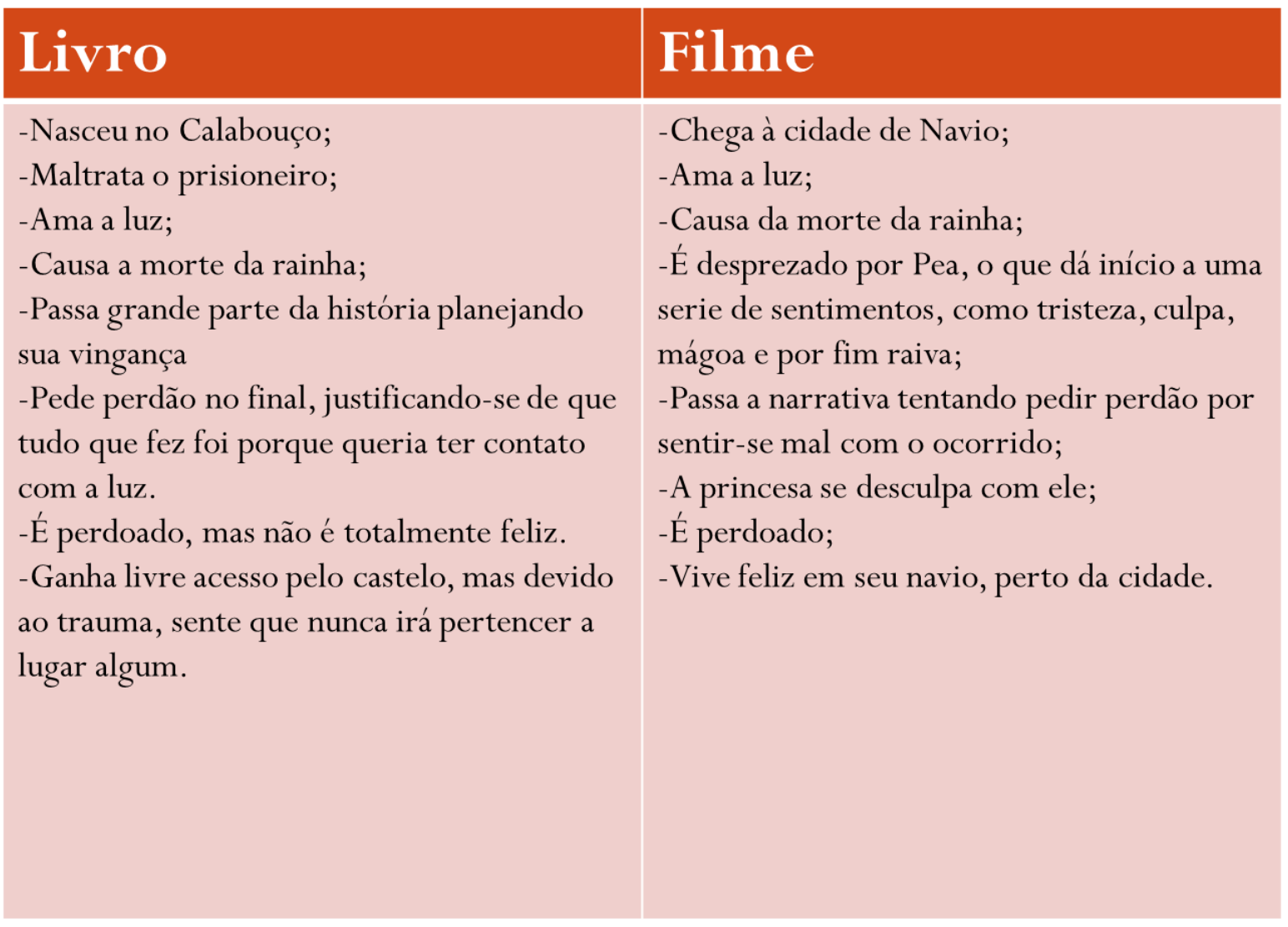

Tabela 3 - Personagem Roscuro: livro e animação. 


\subsubsection{Personagem Pea}

A Princesa Pea é uma personagem que integra a trama como impulsionadora dos fatos ocorridos. Sua atuação começa quando a rainha morre de susto em decorrência da queda de Roscuro em sua sopa. A partir deste episódio, Pea está sempre olhando para coisas que lembram sua mãe. Sua solidão é representada pela soma de cenas em que ela está sozinha, olhando pela janela, desejando que tudo fosse melhor.
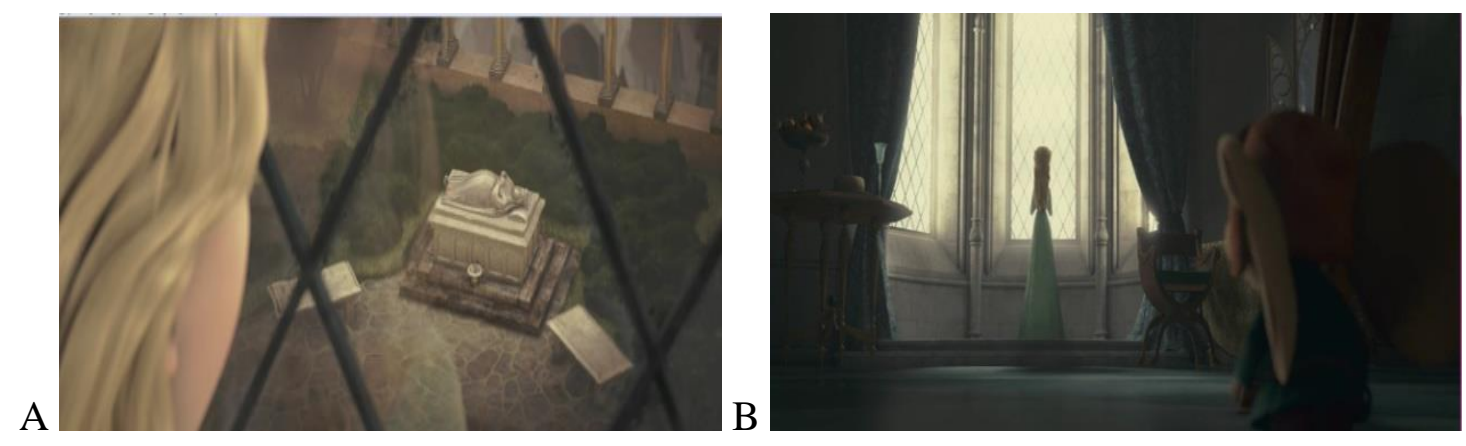

Figura 34 - Solidão da Princesa Pea após a morte de sua mãe.

Sua tristeza é estimulada pela ausência do pai, que nas poucas vezes em que aparece, encontra-se chorando, sozinho em seu canto. A postura melancólica do rei diante da morte da esposa é retratada por sua omissão. Enfatizando-se o cenário, escuro, praticamente vazio e cinza, o Plano Geral Aberto o mostra sentado em direção ao retrato da rainha, representando seu sentimento de desamparo. 


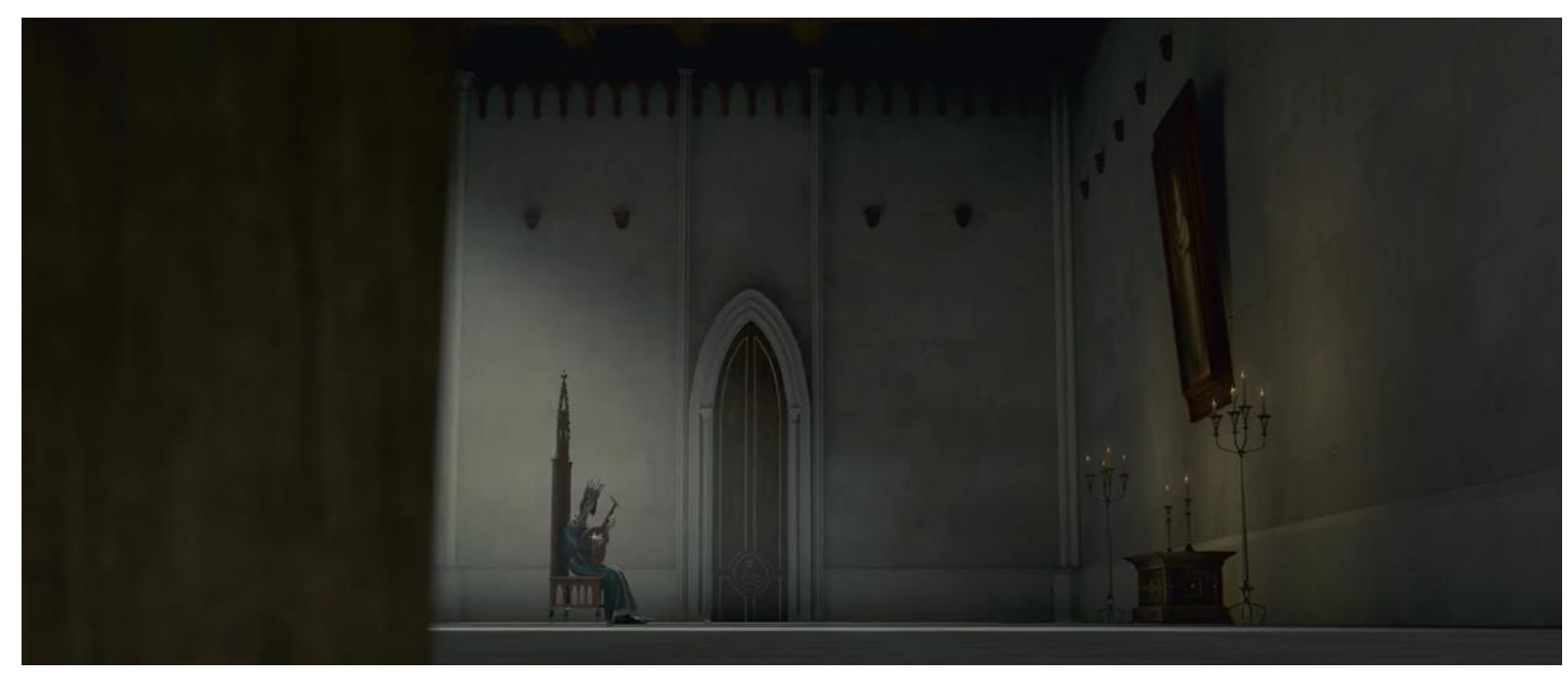

Figura 35 - Solidão do Rei após a morte da Rainha.

As consequências da atitude drástica do rei em proibir a sopa e as ratazanas, castigando, de certa forma, todo o reino de Dor são explicadas pela narradora:

Quando algo machuca tanto precisa existir um motivo. Precisa haver alguém a quem se possa culpar. Então pense... O que acontece quando se torna ilegal algo que faz parte da natureza? É como tornar as moscas ilegais, ou o suor, ou as manhãs de segunda-feira. Mas foi isso que o rei fez devido a uma tristeza terrível. A luz do sol se foi e o mundo se tornou cinzento. As cores se esvaeceram e as nuvens negras cobriram o céu. E por muito tempo não chovia. As nuvens apenas foram ficando e ficando...

A decisão do rei repercute inclusive, em Pea, que percebe que tal proibição entristeceu a cidade. Ela comenta que gostaria que tudo voltasse a ser como antes, inclusive com as ratazanas. Enquanto o rei se fecha em sua amargura, a princesa continua com suas obrigações com o reino ao aparecer em pé, com a serviçal ajustando seu vestido real. Atitudes como essa mostram seu lado sensível e altruísta, que mesmo estando triste, mantém-se firme em prol do povo. 


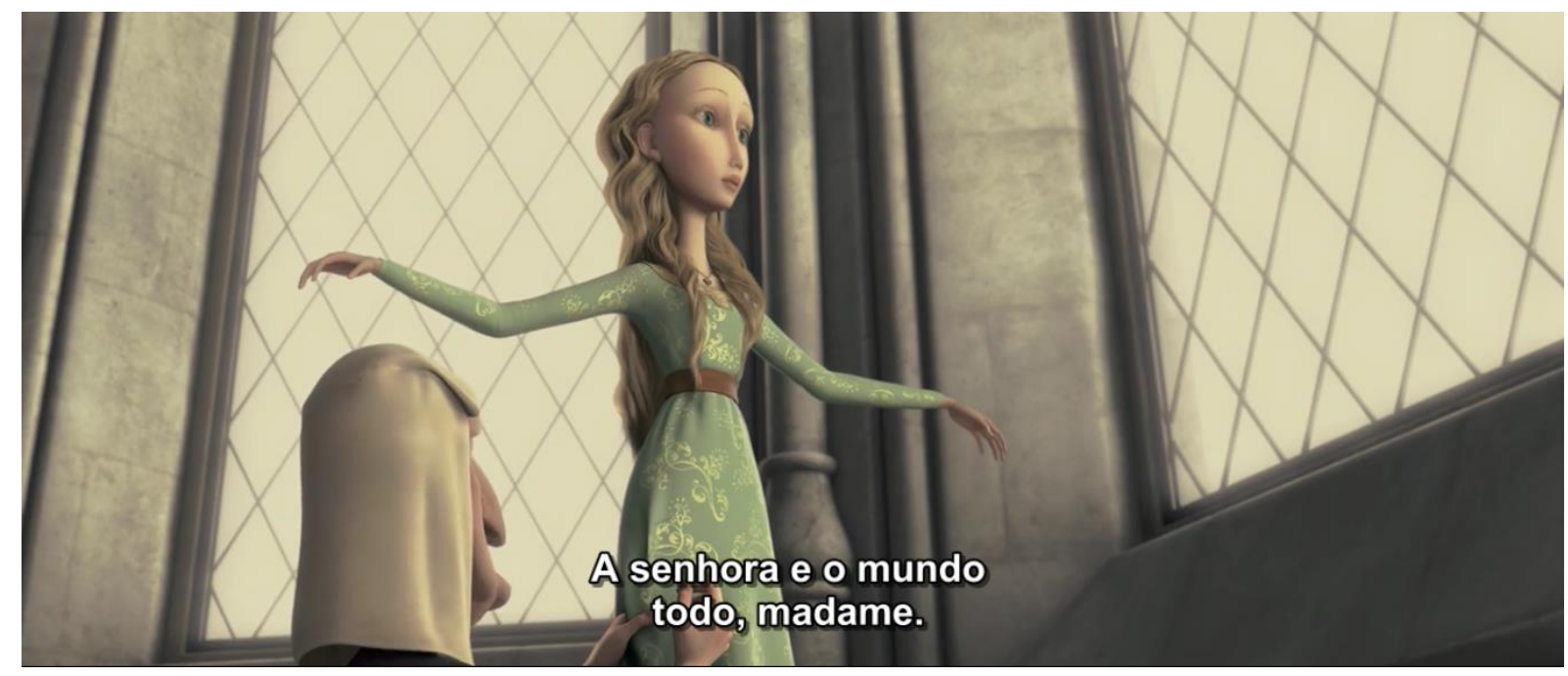

Figura 36 - A majestade de Pea.

Sua atitude nobre ao assumir que errou com Miggery e Roscuro faz com que o perdão mútuo afaste qualquer possibilidade de remorso diante das más escolhas trazendo a paz e reconciliação para os personagens. Sua maior alegria é reaproximar-se do pai, que se desculpa com o povo e com a imagem da esposa e retoma suas obrigações reais.

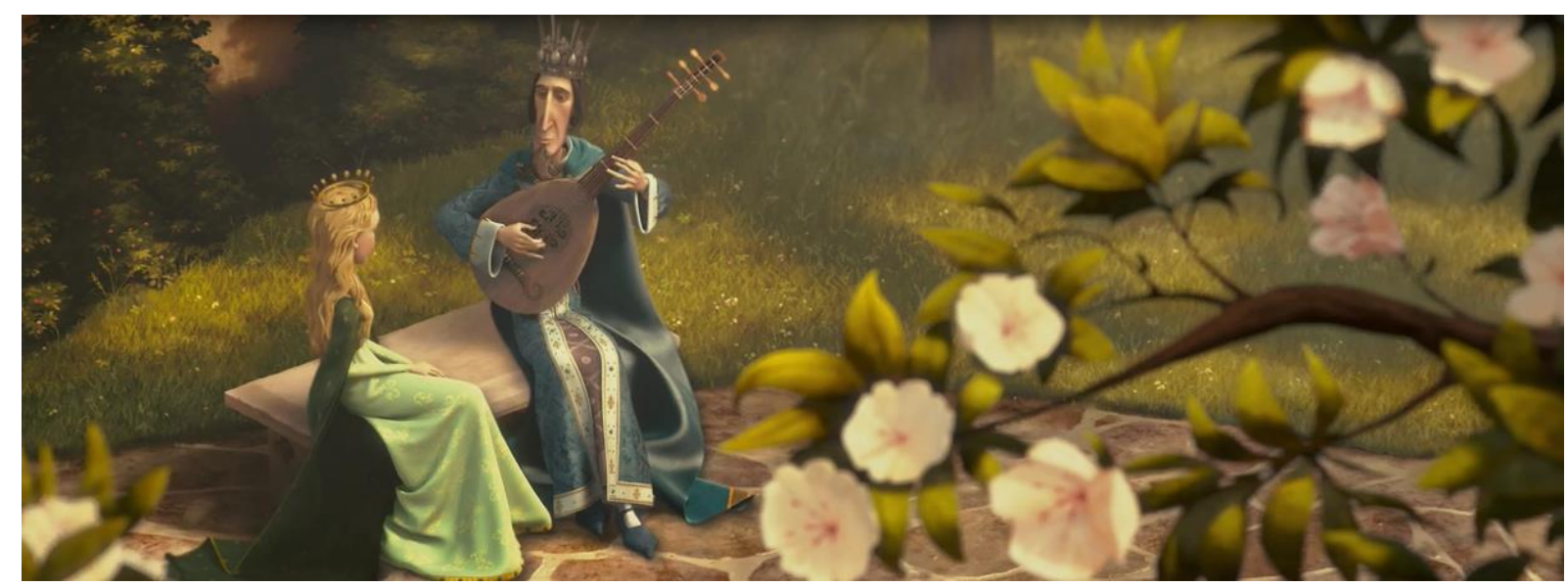

Figura 37 - Princesa Pea se reaproxima do pai.

Como um típico conto de fadas contemporâneo, encerra-se a história com um final feliz a todos os merecedores. Assim como no livro, a narradora destaca que para eles o "felizes para sempre" é relativo. Ele vem conforme a redenção de cada personagem:

Então, poderia chamar tudo isso de um grande mal-entendido se quiser. Um rei magoado, resolve magoar os outros. Uma ratazana foi magoada, então magoou uma princesa e uma princesa magoada, magoou uma serviçal sem ter nem mesmo intenção de o fazer. E essa serviçal tem vivido magoada há tanto tempo que quase 
nada poderia fazê-la se sentir melhor. Mas, foi somente um erro ou é apenas boa sorte? Porque a serviçal voltou para sua fazenda. E o carcereiro finalmente encontrou sua princesa. E o rei encontrou algo mais forte que a amargura. E os camundongos finalmente venceram seus medos. E as pessoas de Dor, agora, vivem lado a lado com as ratazanas, todos, exceto um, que voltou para o mar e sentiu uma brisa fresca soprando, e o sol batendo em seu rosto, todas as tardes. E poderia lhes dizer que todos viveram felizes para sempre. Mas... que graça tem isso?

A princesa Pea é caracterizada como vítima e simultaneamente personagem desencadeador das desventuras na história. No livro, apesar de ter causado a ira de Roscuro e Miggery, a culpa recai para Roscuro que, ao causar a morte da rainha, entristece a família real e ocasiona a proibição da sopa e dos ratos na cidade, punindo indiretamente toda a população das três sociedades. $\mathrm{Na}$ animação, a morte da rainha é apenas o fator responsável pelas proibições. A tristeza da família real se dá pela situação no todo, a seca, a falta da sopa, da mãe/esposa e da alegria no reino. A apatia do rei e a forma com que Pea trata Roscuro tornam-se pivô do efeito bola de neve na trama. No livro, a princesa somente o perdoa para que não se sinta mal consigo mesma. Na animação, em uma postura superior, digna da nobreza, ela mesma pede perdão. Os planos em que a família real aparece, geralmente, mostram seus estados de espírito em relação ao reino e, no caso de Pea, também a destacam assumindo o controle.

O papel da mulher no conto de fadas contemporâneo mostra personagens femininos em uma perspectiva diferente de antigamente, em que a mulher era vista como um ser frágil e carente de proteção masculina. Em uma visão mais recente, que acompanha a luta das mulheres pela igualdade de direitos, agora ela é retratada como uma personagem forte e a única capaz de comandar o reino.

Baseando-se na estrutura narrativa do livro, divido em 4 partes, a animação apresenta concomitantemente a vida de Miggery, Despereaux e Roscuro. Há, primeiramente, a chegada de Roscuro e seu banimento, o nascimento de Despereaux e o início de sua adolescência e a vida de Miggery já no castelo com rememorações de sua infância indo e voltando para o passado e o presente conforme necessidade de explicação sobre alguma atitude indevida da criada. 
Esse efeito de construção simultânea das histórias é chamado de montagem paralela. Ela é o conjunto de ações conduzidas pela intercalação de fragmentos, com o objetivo de criar-se um significado da sua confrontação e caracteriza-se por sua indiferença pelo tempo, conseguindo aproximar eventos muito distantes e cuja a estrita simultaneidade não é indispensável para uma possível justaposição. Esse paralelismo das ações aproxima sem qualquer coexistência temporal ou espacial acontecimentos que serão posteriormente confrontados para que haja uma significação ideológica e simbólica (MARTIN, 2013, p.200201)

Pensando em ambas as versões como instrumentos socioeducativos, a abordagem de estratégias deve ser empregada como mediação entre contextos, práticas e costumes sociais de várias culturas. A natureza intercultural no caso de uma adaptação voltada para o público infantil que tem por objetivo elucidar atitudes ruins por meio de efeitos morais se conduz não por choques culturais, mas por reflexões norteadas pelo senso comum ocidental. Neste caso, esse tipo de adaptação intercultural coaduna-se com a teoria de Pavis, sobre a metáfora da ampulheta, objeto que simboliza o trânsito de uma cultura para outra. Na parte superior está a cultura-fonte, em tese, codificada e solidificada em modelizações antropológicas, socioculturais e artísticas, na inferior, a cultura-alvo ressignifica e decanta-se no objeto artístico desenvolvido (PAVIS, 2008, p. 3). "Esse processo, muito mais controlado pelo hemisfério inferior (ou seja, a cultura-alvo), está marcado pela capacidade da cultura-alvo de recorrer a elementos específicos da cultura-fonte que condigam com suas preocupações estéticas e seus pressupostos socioculturais." (SILVA, 2012, p.209).

Com relação aos conceitos estruturantes, há de se lembrar que esse tipo de adaptação é resultado de sistemas semióticos e contextos de criação/recriação diferentes, o que faz com que haja uma reconfiguração de sentidos do texto-fonte na materialidade estilística do textoalvo. Segundo Peraya (1997, p.304), a comunicação como instrumento de disseminação de noções de mundo preconcebidas a crianças, por sua vez, compreenderia ações menos sistemáticas, refletindo-se menos de forma pedagógica (escolar), constituindo-se naturalmente pela prática da vida social, mostrando comportamentos e conhecimentos indispensáveis ao ser humano, ensinando-o a integrar-se harmoniosamente à sociedade. Na visão de Massai e Silva,

Desse modo, levando em consideração a relação entre literatura e cinema, podemos, portanto, afirmar que a adaptação de textos literários para o cinema também contribuiu para o processo de identificação da criança com os filmes. Mas essa 
contribuição se dá de forma positiva ou negativa, de modo que é preciso refletir sobre os padrões de comportamento que estão sendo oferecidos à criança. Além disso, a literatura não produz o jogo de marketing utilizado pelo cinema que, por sua vez, promove imagens mais realistas e chocantes. Afirmar isso não se trata de censura, mas de responsabilidade social diante de uma produção cultural que está sendo oferecida para um público específico: a criança, indivíduo que se encontra em processo de formação (MASSAI; SILVA, 2011, p.7). 


\section{CONCLUSÃO}

Tendo-se como ponto de partida a ideia de tradução como reescritura, transformandose a partir da cultura do público-alvo, o livro The Tale of Despereaux: being the Story of a Mouse, a Princess, Some Soup, and a Spool of Thread constitui-se de uma atualização aos contos de fadas tradicionais, abordando os problemas que atingem o leitor em desenvolvimento, mas com conceitos atuais. A obra contemporânea calcada no conto de fadas tradicional proporciona uma nova construção e um novo olhar sobre a representação dos personagens, visto que a cultura do público-alvo é um fator preponderante para a adaptação em questão.

Partindo-se do pressuposto da tradução como recriação, em que necessariamente modifica-se o texto de partida, pensa-se nas transformações ocorridas não só pela exigência da mudança de sistema semiótico como também do público. Retomando a discussão proposta por Ricardo Azevedo (1999), sobre as diferentes faixas etárias e a preparação de uma história para diversos públicos, The Tale of Despereaux, como a maioria das animações populares voltadas para o público infantil, foi indicada como classificação livre. Mesmo que seja acessível a crianças menores de dez anos, a narrativa é um convite a todas as idades, pois se aproxima do texto de partida ao estruturar-se de modo a recriar contextos socialmente estruturados em prol da transmissão de um efeito moral.

Livro e animação mantiveram algumas das temáticas mais recorrentes nos contos de fadas como abandono, rejeição, redenção e acolhimento. A construção dos personagens em ambos se dá de modo similar, mas os sentimentos na narrativa fílmica na hora de tomar atitudes são mais humanizados. Roscuro chora muito, pensa em pedir perdão e tem de ser menosprezado mais de uma vez para querer se vingar de fato. Miggery passa por inúmeras tragédias, mas só cria ódio pela princesa quando ela lhe faz uma ofensa pessoal. Pea aparece desde o começo da história sendo altruísta, não se entregando à tristeza e arrependendo-se ao agir mal com os outros, ao exemplo da cena de Miggery chateada e a princesa ao fundo a observando com olhar melancólico. 
Sobre a personalidade de Despereaux, ele se mantém sempre esperançoso e sonhador, sem nenhuma falha de caráter. A maior diferença nas versões é que, no filme, ele está sempre otimista, vendo tudo como uma aventura em que deve salvar a princesa e, no livro, suas decepções com seus parentes quebram o clima de mar de rosas que ele cria em sua imaginação. Despereaux possui um momento decisivo, na obra literária, com relação a si mesmo quando tem de decidir se perdoa ou não seu pai. No final da história, fica claro que o perdão ocorreu apenas para que ele não alimentasse rancor dentro de si, ao mostrar sua família bem de longe, observando a reviravolta na vida do camundongo.

Os recursos cinematográficos foram importantes para a construção minuciosa da compreensão por parte do espectador na expressividade sobre aspectos relacionados ao eu; ao sentimento de cada personagem para consigo mesmo e, consequentemente, na forma que os vemos. Dentre os planos mais utilizados, destacam-se o Plano Conjunto, utilizado para contrastar as reações antagônicas entre protagonistas e personagens secundários diante das normas a serem seguidas; o Plano Detalhe, para enfatizar eventos traumáticos, como no caso do close no olhar de Pea para Roscuro e no ouvido de Miggery ao ouvir claramente ser chamada de ridícula; o contraplongée, utilizado com o intuito de produzir a sensação de fragilidade de Roscuro e Despereaux em relação aos ataques e também para sugerir a superioridade dos líderes de cada sociedade; o Plano Geral Aberto e o Grande Plano Geral, para situar personagens nos locais onde eles gostariam de estar, bem como colocar em evidência seus objetos de desejo.

Observou-se, também, a incidência de posicionamentos de câmera na altura do campo de visão dos personagens, mostrando parte de seu corpo com a cabeça direcionada para onde o espectador deve olhar. Subentende-se essa escolha como estratégia para integrar o espectador à história, como se fosse a visão de mais um personagem, tendo em vista que a proposta da narrativa literária é fazer o leitor colocar-se no lugar dos protagonistas.

Nesse sentido, o ponto de vista se constrói pelo conjunto de efeitos gerados pelas escolhas cinematográficas com a amenização de sentimentos negativos em conjunto com a interferência do narrador. A perspectiva dos personagens sobre a própria realidade no filme fica clara pelos diferentes planos que, a depender do sentimento a ser mostrado, induz o olhar do espectador para o objeto de foco do personagem ou evidencia suas expressões faciais. 
Com isso, os pontos de vista dos protagonistas são construídos para se ilustrar como cada ação dessas sociedades atua em seu psicológico e os levam a agir de determinadas maneiras. Já os pontos de vista na narrativa literária ratificam filosofias de cunho religioso, como a questão do karma, em que o sofrimento serve para redimir ações, dando-os à chance de ter um final feliz; o valor do perdão, como processo de purificação, ao tirar de si o peso do rancor.

Com relação ao efeito moral, ambos partem da perspectiva de que a forma como a sociedade se constitui não deve ser aceita sem se averiguar se nela há realmente uma preocupação com o bem comum. No livro, junta-se as perspectivas dos protagonistas à forma como cada sociedade se construiu, rejeitando-os, de modo que os habitantes não percebam o quanto podem prejudicar o outro ao seguirem regras que não necessariamente são boas, tendo-se como propósito maior mostrar ao leitor a necessidade de se ter conhecimento e cultura para que ele saiba exercer seus direitos como cidadão futuramente. Ao passo que o efeito moral no filme tem por objetivo mostrar sob uma visão ética, as consequências que ações impensadas podem ter na vida daqueles que não se enquadram em uma sociedade homogênea.

Procurou-se analisar a tradução como um todo, optando-se por destacar eventos de mais impacto na vida dos protagonistas. Apresentam-se algumas supressões de elementos que não seriam adequados para o público contemporâneo, que é cada vez mais direcionado a narrativas politicamente corretas. Tudo transcorre buscando-se a transmissão de conceitos ético-morais. Nesse aspecto, ocorre o procedimento tradutório de equivalência situacional, em que o ponto de vista ilustrado na adaptação corrobora com conceitos voltados para o reconhecimento por parte do público com as ideologias atuais.

Todas as atitudes consideradas antiéticas foram parcialmente suprimidas, sendo mostradas de forma que ficassem subentendidas, como no caso da violência do tio de Miggery, que gerou sua deficiência, a linha vermelha, simbolizando pena de morte para Despereaux ou mesmo a atitude fria de sua mãe ao dizer "adieu".

Chama-se atenção para o caráter didático do narrador do texto literário que critica em demasiado as atitudes erradas dos personagens, a forma como cada sociedade se constitui e a submissão das comunidades diante das normas. Por vezes de forma agressiva, ele incita o 
leitor a trazer os acontecimentos para sua realidade de modo a fazê-lo diferenciar o certo do errado por meio da catarse. Seu papel moralizador aponta problemas sociopolíticos que podem facilmente ser transpostos à vida real, um dos motivos pelo qual o livro é bastante utilizado em escolas europeias e americanas.

$\mathrm{Na}$ animação, o narrador explica algumas ações negativas dos protagonistas, procurando acentuar seu lado bom, e a crítica às sociedades se dá pelas reações contrárias destes ao meio em que vivem, ao jogo de câmera e por alguns comentários que um ou outro personagem faz. Os ensinamentos aparecem por meio de "ação e reação". O sistema audiovisual por si só transmite sensibilidade ao espectador fazendo-se uso de efeitos sonoros, expressões faciais e corporais, efeitos de luz e sombra e posicionamento de câmera. Com isso, as más atitudes são destacadas, demonstrando-se por meio desses efeitos a contrariedade em relação à elas.

Esse trabalho buscou mostrar que embora muito antigos, os contos de fadas ainda conseguem nos transmitir valores e ensinar sobre nós mesmos. De acordo com Bettelheim (1980, p.6):

Esta é exatamente a mensagem que os contos de fada transmitem à criança de forma múltipla: que uma luta contra dificuldades graves na vida é inevitável, é parte intrínseca da existência humana - mas que se a pessoa não se intimida, mas se defronta de modo firme com as opressões inesperadas e muitas vezes injustas, ela dominará todos os obstáculos e, ao fim, emergirá vitoriosa (BETTELHEIM, 1980, p.6). 


\section{REFERÊNCIAS}

AZEVEDO, R. Conto popular, literatura e formação de leitores. Cultura popular e educação. Brasília: Ministério da Educação, Secretaria de Educação a Distância (2008).

BACHELARD, G. A poética do devaneio. São Paulo: Martins Fontes, 1988.

BAKER, M. G. S. (eds.) Routledge Encyclopedia of Translation Studies. London \& New York: Routledge, 2nd edn. 2008

BAKHTIN, M. Estética da criação verbal. São Paulo: Martins Fontes. 2002.

BARBOSA, M. T. A. Por uma mitologia poética dos contos de fadas no Brasil. Letras de Hoje. Porto Alegre, v. 26, n.3, p. 1-167, set. 1991.

BASSNETT, S.; LEFEVERE, A. (Orgs.). Translation, History and Culture. London: Pinter, 1990.

BAZIN, A. O Cinema: Ensaios. São Paulo: Brasiliense, 1991.

BEATRICE, L.; LAURINDO, R. Contos de fadas na publicidade: magia e persuasão. Blumenau: Edifurb, 2009.

BETTELHEIM, B. A psicanálise dos contos de fadas. Trad. Arlene Caetano. Rio de Janeiro: Paz e Terra, 1980.

BOURNEUF, R.; OUELLET, R. O universo do romance. Coimbra; Almedina, 1976.

CANDIDO, A. A literatura e a formação do homem. In: Ciência e Cultura. São Paulo. USP, 1972.

CANTON, K. "E o príncipe dançou... o conto de fadas, da tradição oral à dança contemporânea." São Paulo: Ática (1994).

Era uma vez Perrault. São Paulo - SP. 1 ed. 2005a.

Era uma vez Andersen. São Paulo - SP. 1 ed. 2005b.

CARVALHO, E. A. As relações entre Educação e os Diferentes Contextos Culturais. In:

Didática. São Paulo, 25, 1989, p.19-26.

CATFORD, J. C. 1965. A Linguistic Theory of Translation: An Essay in Applied Linguistics. London: Oxford University Press.

CECHIN, M. B. C. O que se aprende com as princesas da DISNEY? Zero-a-Seis 16.29 (2014): 131-147. 
CHORÃO, M. A Dobragem em Portugal: Novos Paradigmas da Tradução Audiovisual. Tese de Doutoramento. Vigo. Universidade de Vigo, 2013.

CHATMAN, S. Story and discourse: narrative structure in fiction and film. London: Cornell University Press, 1978.

COELHO, N. N. O conto de fadas: símbolos, mitos, arquétipos. DCL, 2003.

CORSO, D.L; CORSO, M. Fadas no divã: psicanálise nas histórias infantis. Porto Alegre: Artmed, 2006.

COUTO, M. E. S., CAMPOS, G. V., Os contos de fadas: a leitura e a construção do imaginário Infantil. I Congresso Nacional de Linguagens e Representações: linguagens e leituras. UESC - ILHÉUS-BA. outubro de 2009.

DIAZ-CINTAS. J. In search of a theoretical framework for the study of audiovisual translation. In: ORERO, Pilar (ed). Topics in Audiovisual Translation. Amsterdam and Philadelphia: John Benjamins, 2004.

DÍAZ-CINTAS, J. Traducción audiovisual y accesibilidad In: Traducción y accesibilidad Subtitulación para sordos y audiodescripción para ciegos: nuevas modalidades de Traducción Audiovisual. Frankfurt: Peter Lang, 2007. p. 9-23.

DICAMILLO, K. (2003). The Tale of Despereaux: Being the story of a mouse, a princess, some soup, and a spool of thread. Cambridge: Candlewick Press.

DINIZ, T. F. N. Tradução intersemiótica: do texto para a tela. Cadernos de Tradução, número 3, Florianópolis, 1998. p. 313-338.

ECO, U. Seis passeios pelos bosques da ficção. São Paulo: Companhia das Letras, 1994.

EISENSTEIN, S. Reflexões de um cineasta. Tradução Gustavo A. Doria. Rio de Janeiro, Zahar, 1969.

ELY, T.C., ZANESCO, V.M.F. A ruptura dos contos de fadas em História meio ao contrário. In: XI Seminário Nacional de Literatura, História e Memória e II Congresso Internacional de Pesquisa em Letras no Contexto Latino-Americano. 2013, Cascavel, PR, Unioeste, 2013.

ESSLIN, M. The Field of drama: how the signs of drama create meaning on stage \& screen. London: Methuen, 1990.

EVEN-ZOHAR. Polysystem theory. In: Poetcis today, Tel Aviv, v 1, n.1/2, 1979. p.287-310. 
FARIAS, F. R. A; RUBIO, J. A. S., Literatura Infantil: A Contribuição dos Contos de Fadas para a Construção do Imaginário Infantil. Revista Eletrônica Saberes da Educação - Volume $3-\mathrm{n}^{\mathrm{o}} 1-2012$.

FOUCAUlT, M. A Hermenêutica do Sujeito: curso dado no Collège de France (19811982). São Paulo: Martins Fontes 2004.

FRIEDMAN, N. O ponto de vista na ficção: desenvolvimento de um conceito. In: Revista USP, $n^{\circ}$ 53. São Paulo: USP, 2003.

GAMBIER, Y. Screen Transadaptation: Special Issue. The Translator. Special issue on Screen Translation, v. 9, n. 2, p. 191-205, 2003.

GERZYMISCH-ARBOGAST, H. Introducing multidimensional translation. In: MuTRA: challenges of multidimensional translation, Saarbrücken Proceedings, Saarbrücken: Saarland University, 2005. p.1-15.

HERMANS, T. Translation Studies and a New Paradigm. In: ___ (Org.) The Manipulation of Literature. London: Croom Helm, 1985. p. 7-15.

ISER, W. O ato de leitura: uma teoria do efeito estético. Trad. Johannes Kretschmer. São Paulo: Ed. 34, 1996.

JAKOBSON, R. Linguística e comunicação. São Paulo: Cultrix (trad. de Izidoro Blikstein e José Paulo Paes), 1995.

JAUSS, H. R. A história da literatura como provocação à teoria literária. Trad. Sérgio Tellaroli. São Paulo: Ática, 1994.

JOLLES, A. O conto. In: 1976. p. 181-204. . Formas simples. Trad. Álvaro Cabral. São Paulo: Cultrix,

KHÉDE, S. S. Personagens da literatura infantojuvenil. São Paulo: Editora Ática, 1990.

LARROSA, J. Tecnologias do eu e educação. In: Silva, T. T. da (org.). O sujeito da educação: estudos foucaultianos. Petrópolis: Vozes, 1995

LEFEVÈRE, A. Tradução, reescrita e manipulação da fama literária. Trad. Claudia Matos Seligmann. Bauru, SP: Edusc, 2007.

MARTIN, M. A linguagem cinematográfica. São Paulo: Brasiliense, 2003.

MARTINS, M. A. P. As contribuições de André Lefevere e Lawrence Venuti para teoria da tradução. Cadernos de Letras (UFRJ) n.27,1-14p. Dez. 2010.

MASSAI, F.A.; SILVA, A.R. O comparativismo entre semióticas: A personagem madrasta na literatura e no cinema. Revista Fronteira Digital, n.3, jan -ago, 2011. 
MEDEIROS. K.B., FONSECA, V.M.F., SOUZA, S.C.M, SILVA, A.A. LARCERDA, J.S. O Audiovisual como propulsor da Produção do Conhecimento na disciplina Teoria da Comunicação. Intercom - Sociedade Brasileira de Estudos Interdisciplinares da comunicação XVI Congresso de Ciências da Comunicação na Região Nordeste-João Pessoa - PB. 2014.

MONACI, E. M. (1990). Mitos, contos, lendas e fábulas: fantasia versus realidade. Revista Brasileira de Pesquisa em Psicologia, 2 (2), 42-54.

MORIN, E. A cabeça bem feita: repensar a reforma, repensar o ensino. $11^{\text {a }}$ ed., Trad. Eloá Jacobina. Rio de Janeiro: Bertrand Brasil, 2005.

MINISTÉRIO DA JUSTIÇA. Classificação indicativa: Guia prático. $2^{\mathrm{a}}$ ed. Brasília, 2012. $44 \mathrm{p}$.

NIDA, E. TABER. C. The Theory and practice of translation. In: Brower (ed). On Translation, Cambridge, Harvard University Press.

OUSTINOFF. M. Tradução: História, teorias e métodos. Tradução de Marcos Marcionilo. São Paulo: Parábola Editorial, 2011, 144 p.

PAVIS, P. O teatro no cruzamento de culturas. São Paulo: Perspectiva, 2008.

PLAZA, J. Tradução Intersemiótica. São Paulo: Perspectiva, 2003.

PETRY, H.; SILVA, R. D. Os arquétipos nas propagandas de revistas femininas. In: Alegre. Anais... São Paulo: Intercom, 2004. 1 CD-ROM.

PROPP, V. I. Morfologia do conto maravilhoso. Rio de Janeiro: Forense, 1984.

RANDAZZO, S. A Criação de Mitos na Publicidade: como publicitários usam o poder do mito e do simbolismo para criar marcas de sucesso. 1a edição. Rio de Janeiro: Racco, 1997.

REYES, J. O. O filme como leitor do texto literário: reflexões teóricas. Anais do IX Seminário Nacional de Literatura Histórica e Memória-Literatura do Cinema e III Simpósio Gêneros Híbridos da Modernidade - Literatura no Cinema. SP; 2009.

RICHARDS, J. Sexo, desvio e danação: as minorias na Idade Média. Trad. Marco Antonio Esteves da Rocha e Renato Aguiar. Rio de Janeiro- RJ: Jorge Zahar Ed., 1993.

RICHE, R. M. C. Literatura infantojuvenil contemporânea: texto/ contexto-caminhos/ descaminhos. Perspectiva, Florianópolis, v. 17, n. 31, p. 127-140.

RICHTER, I. M. Interculturalidade e estética do cotidiano no ensino das artes visuais. Mercado de Letras, 2003.

SANTAELLA, L. Corpo e comunicação: o sintoma da cultura. São Paulo: Paulus, 2004. 
SANTOS, M. M.. "Por um lugar para a literatura infantil/juvenil nos estudos literários." Tese de doutoramento.Universidade Federal da Bahia, Instituto de Letras, Salvador, 2011.

SCHLEIERMACHER, F. Sobre os diferentes métodos de tradução. Trad. Margarete von Mühlen Poll. In: HEIDERMANN, W. (Org.). Clássicos da teoria da Tradução: antologia bilíngüe, v. I, alemão-português. Florianópolis: UFSC, Núcleo de Tradução, 2001. p. 26-87.

SEGALA, R. Tradução Intermodal e Intersemiótica/Interlingual: Português brasileiro escrito para a Língua Brasileira de Sinais. Dissertação (Mestrado) - Universidade Federal de Santa Catarina, Centro Comunicação e Expressão, Programa de Pós-graduação em Estudos da Tradução. Florianópolis, 2010.

SEGOVIA, R. (2009). Transfer Phenomena and Intercultural Movements of Texts. Journal of Intercultural Communication, 19p.

SILVA, T. T. Documentos de Identidade: uma introdução às teorias do currículo. Belo Horizonte: Autêntica, 2007.

SILVA, M. A. L., BARROS, R. B., NASCIMENTO, T. A. M. N., A importância dos contos de fadas na educação infantil. IV FIPED - fórum internacional de pedagogia. Parnaíba - PI. Campina Grande, REALIZE Editora, 2012.

SILVA, G., DIOGO, A.; AZEVEDO, F. (2008). Mitos e temas revisitados na literatura infantojuvenil contemporânea: uma literacia de (re)criação. Congresso Internacional em Estudos da Criança "Infâncias Possíveis, Mundos Reais. Braga : Instituto de Estudos da Criança.

SILVA, M. V. B. Adaptação intercultural: em busca de um modelo analítico. Significação, São Paulo, v. 1, n. 38, p.198-226, dez. 2012.

TATAR, M. (Introd. e notas). Contos de Fadas. Edição comentada e ilustrada. Rio de Janeiro: Jorge Zahar Editor, 2004.

THEODORO. A.C.N., PINTO. D.C. Projeto de criação artística: a prática de leitura e a produção textual a partir de um estudo comparativo dos contos de fadas e do cinema. .Anais do SIELP. Volume 2, Número 1. Uberlândia: EDUFU, 2012.

THOMAZ, O. R. A Antropologia e o Mundo Contemporâneo: cultura e diversidade. In: SILVA, Aracy L. da; GRUPIONI, Luís D. B. (orgs.). A Temática Indígena na Escola: Novos subsídios para professores de $1^{\circ}$ e $2^{\circ}$ graus. Brasília: MARI/MEC/UNESCO, 1995, p. 425441.

VELHO, G; CASTRO, E.B.V. O Conceito de Cultura e o Estudo das Sociedades Complexas: uma perspectiva antropológica. In: Artefato - Jornal de Cultura. Ed. Conselho Estadual de Cultura. Ano 1, nº 1, janeiro 1978.

VENUTI, L. The translator's invisibility - A history of translation. London: Routledge, 1998. 
A invisibilidade do tradutor. Trad. Carolina Alfaro. PaLavra 3, p. 111-134, 1995. Tradução de The Translator's Invisibility. Criticism, Wayne State UP, v. XXVIII, n. 2, p. 179-212, Spring 1986.

Escândalos da Tradução: por uma ética da diferença. Trad. Laureano. Pelegrin, Lucinéia Villela, Marileide Esqueda e Valeria Biondo. Bauru, S.P.: EDUSC, 2002.

VIEIRA, E. R. P. André Lefevere: a teoria das refrações e da tradução como reescrita. In: (Org.) Teorizando e contextualizando a tradução. Belo Horizonte: Faculdade de

Letras da UFMG, Curso de Pós-Graduação em Estudos Linguísticos, 1996. p. 138-150.

VIGOTSKY, Lev Semenovitch. O desenvolvimento psicológico na infância. São Paulo:Martins Fontes, 1999.

WOODWARD, K. Identidade e diferença: uma introdução teórica e conceitual. In: SILVA, Tomaz Tadeu da Silva (Org.). Identidade e diferença: a perspectiva dos estudos culturais. Tradução Tomaz Tadeu da Silva. Rio de Janeiro: Vozes, 2007.

XAVIER, I. Do texto ao filme: A trama, a cena e a construção do olhar no cinema. In: PELLEGRINI, Tânia [et al.]. Literatura, cinema e televisão. São Paulo: SENAC: Instituto Itaú Cultural, 2003.

\section{Filmografia:}

O Corajoso Camundongo Despereaux - The Tale of Despereaux. Direção Sam Fell / Robert Stevenhagen. Inglaterra / EUA: Produtoras Framestore Feature Animation, Larger Than Life Productions, Relativity Media, Universal Animation Studios, Universal Pictures, distribuidora Universal Pictures do Brasil, 2009. DVD (93 min), som, cor. 